\title{
UC-NRLF
}

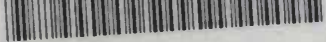
\$B 279 12己2

SCIENCE AND SCIENTISTS 

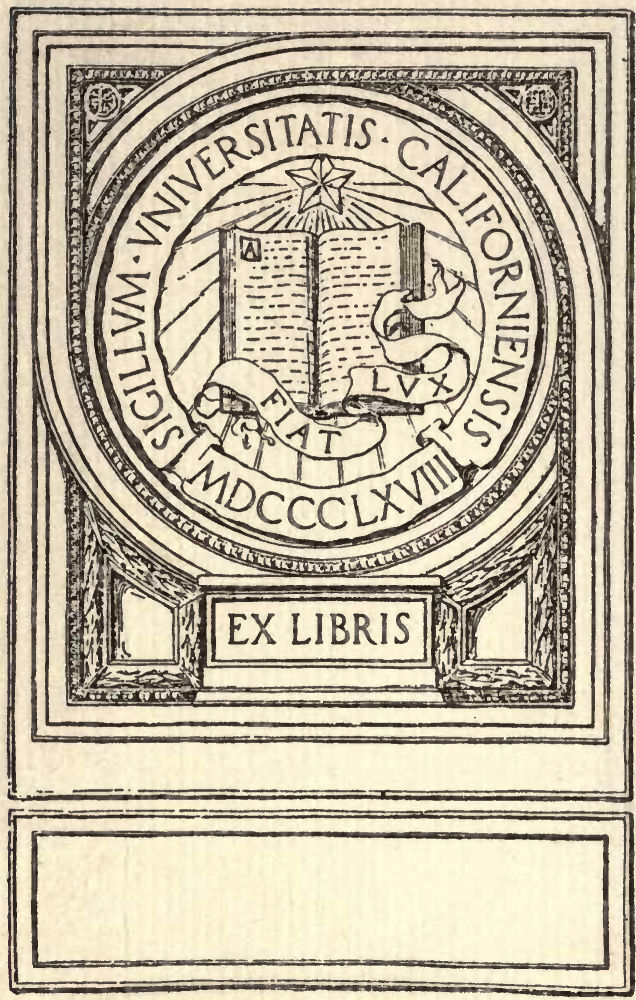




\section{SCIENCE AND SCIENTISTS}

BY THE

REV. JOHN GERARD, S.J., F.L.S.

SECOND EDITION

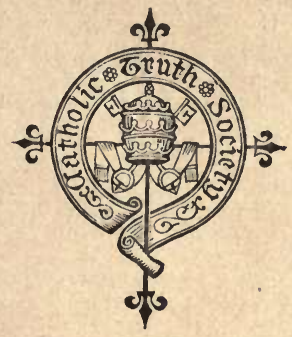

LONDON

CATHOLIC TRU'H SOCIETY

69 SouthWark Bridge Road, S.E.

I906 


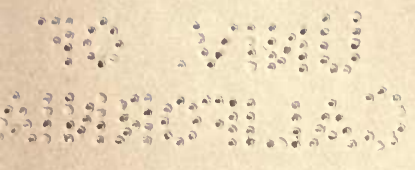

PRINTFD AND PUBLISHED BY THE CATHOLIC TRUTH SOCIETY 69 SOUTHWARK BRIDGE ROAD, LONDON, S.E. 


\section{. CONTENTS}

MR. GRANT ALLEN'S-BOTANICAL FABteS ? I WHO PAINTED THE FLOWERS? $\quad . \because: \because ; . ;$ I SOME WAYSIDE PROBLEMS • . . . . . 45 "BEHOLD THE BIRDS OF THE AIR" . . . . 6I HOW THEORIES ARE MANUFACTURED $\because \cdots 77$ INSTINCT AND ITS LESSONS . . . . . IOI 


\section{BY THE SAME AUTHOR}

UNIFORM WITH THIS YOLUME

Price One Shilling, Cloth. By Post is. $2 d$.

\section{SCIENCE OR ROMANCE?}

1. A TANGLED TALE

2. MISSING LINKS

3. THE GAME OF SPECULATION

4 THE EMPIRE OF MAN

5. THE NEW GENESIS

6 THE VOICES OF BABEL

The above Chapters, like those in the present Volume, may be had separately, price ONE Penny each. 


\section{Silsr. Grant Alllen's JBotanical Jfables}

"Every one of these English plants and weeds has a long and eventful story of its own. In the days before the illuminating doctrine of evolution had been preached, all we could say about them was that they possessed such and such a shape, and size, and colour: and if we had been asked why they were not rounder or bigger or bluer than they actually are, we could give no sufficient reason, except that they were made so. But since the great principle of descent with modification has reduced the science of life from chaos to rational order, we are able to do much more than that. We can now answer confidently, Such and such a plant is what it is in virtue of such and such ancestral conditions, and it has been altered thus and thus by these and those variations in habit or environment" (Grant Allen, Flowers and their Pedigrees, p. 2).

"The relation of our existing vegetation to preceding floras is beyond the scope of our present inquiry: it has been frequently made the subject of exposition, but to handle it requires a more lively imagination than I can lay claim to, or perhaps than it is desirable to employ in any strictly scientific investigation" (Address to Biological Section, British Association, 1886. By William Carruthers, F.R.S., F.G.S., President of the Section).

THERE is a very active and very influential school of philosophers at the present day who could invent for themselves no better designation than "peripatetics." Not Peripatetics, be it observed, in the traditional and transferred sense: Aristotle they repudiate; and if he had the opportunity, the repudiation would probably be mutual. But, according to the original and literal meaning of the word, they are "walking" sages. They stroll out to the fields, or the moors, or the sea-shore, and every object they meet-beast, bird, insect, or weed-furnishes them with a text wherewith to enforce the great creed formulated by exact science and exact thought concerning the origin of the heavens and the 


\section{Mr. Grant Allen's Botanical Fables}

earth. The late Laureate familiarized us with the truth that in the lowliest of living things there is something that must remain incomprehensible until we shall have fathomed the whole mystery of being :-
Flower in the crannied wall,
I pluck you out of the crannies ;
Hold you here, root and all, in my hand,
Little flower; but if I could understand
What you are, root and all, and all in all,
I should know what God and man is.

Our peripatetics quite agree with the poet, that the key to all truth is needed in order to unlock the riddle of the flower's life; but they differ from him altogether in this, that for them there is no mystery: they have the key, and therefore are they able to compel the blossom to display to us all that we should know, about ourselves, and about the forces which brought us into being.

The writers with whom at present I am concerned, though they are not scientific men, yet claim to speak in the name of Science. They have not themselves engaged in original research, but they profess to expound the discoveries of specialists for the benefit of the general public, a large proportion of whom firmly believe that in them they are listening to the accredited agents of scientific thought. This is not strictly speaking the case, and yet scientific men have in great measure only themselves to thank for the confusion. Writers who publicly profess to popularize the new philosophy, should be publicly disowned if they misrepresent it. Men of science are quick enough to assail the exponents of the old belief when they seem to trench on their own ground: they ought, one would think, to be even more solicitous that the sacred name of science should not lightly be invoked on behalf of unsound doctrine.

It must be remembered too that, whether scientific or not, these writers are eminently popular. They claim for their method, and claim justly, that they can be understanded of the people to a degree which is impossible for those who treat subjects in a more technical 
fashion. Men who are quite incapable of even following an argument based on the structure of a tendon, or on the peculiarities of the "hippocampus major," can pick up a buttercup or a snail-shell and follow with intelligence and interest the lesson which the object is made to illustrate. The great doctrine of evolution can thus alone, it is said, be brought home to the general public; thus alone can be satisfied the yearning, natural to men, for information as to how things came to be as they are.

Now it is perfectly true that things are thus brought home to most of us as they could not otherwise be brought, and an opportunity is given us of forming a judgment on the subject, far more substantial than we could otherwise form. But it may be that this judgment will be adverse to the theories set before us, and that the insight imparted to us into the ways of nature will furnish us with arguments, not for, but against, the exhibitor's creed. The many must needs be mute when the question is referred to niceties of anatomy, but may feel themselves quite as competent to speak as any specialist, when the facts employed as data for discussion demand only a plain pair of eyes to examine them.

Mr. Grant Allen is a notable specimen of the neoperipatetic school. He has applied himself of set purpose to popularize the doctrine of evolution, - a doctrine which he follows to the extremity of determinationism, by taking simple and well-known natural objects, and giving such an explanation as evolutionary principles afford of their more striking external features. $\mathrm{He}$ claims to have at least suggested the right way to go to work in the matter, even though he has not gone very deep. As I have said, I agree with him thus far. He has given plain people an opportunity of forming for themselves a judgment worth something on the subject before them, instead of feeling themselves forced to bow to the ipse dixit of a man who knows how to use a microscope or a scalpel. It may be worth while, therefore, to take his various writings as a sort of running text on which to base some remarks concerning the I.* 


\section{Mr. Grant Allen's Botanical Fables}

figure made by evolutionary argument, not to say by the doctrine of evolution itself, when thus brought within the scope of ordinary vision. ${ }^{1}$ Apart from science, too, the objects to which he leads us may serve to enliven many a summer ramble, and his method, though we may differ widely from his conclusions, will, at least, teach us to use both our eyes and our brains. Which, being premised, let us stroll out with him into the country.

One of his first texts is afforded by a Strawberry-a wild Strawberry growing by a lane side. ${ }^{2} \mathrm{He}$ undertakes to tell us in this, as in all his other instances, how such a product of nature came to its present form. No one, I suppose, in these days of popular lectures and elementary hand-books, needs to be told that what we call the fruit of the Strawberry is not the fruit; but the receptacle or cushion on which the fruit is placed, the fruit being in reality the hard little brown nuts which, if we condescend to notice them at all, we usually call seeds. But while the fruit remains-to ordinary ideas-unfruitlike the receptacle becomes fleshy and juicy and red, and, acquires the flavour which induced old Isaac Walton to say, or at least to endorse the saying, that God could without doubt have made a better berry, but equally without doubt God never did. Now how comes it, asks Mr. Allen, that the Strawberry has developed the habit of producing this succulent and conspicuous cushion? It was not so from the beginning: this was not the "primitive form." The primeval Strawberry fruits were crowded together on a green, dry, inedible receptacle. Whence the change? "Why does the Strawberry develop this large mass of apparently useless matter?"

The answer follows unhesitatingly. For a plant with

1 The works I shall chiefly refer to are The Evolutionist at Large (Chatto and Windus, 188I); Vignettes from Nature (Chatto and Windus, 1881); Flowers and their Pedigrees (Longmans, 1883); and certain articles in Knowledge, incorporated in Nature Studies (Longmans).

${ }^{2}$ Evolutionist at Large, p. 16. 
indigestible fruits, like these little nuts, it was a clear gain in the struggle for life to be eaten by birds, and, consequently, to have something to tempt birds to eat. Some of the ancestral Strawberries chanced to have a receptacle a trifle more juicy than their chaffy brethren, and by virtue of this piece of luck gave birth to more than the usual number of seedlings, all reproducing and some farther developing the maternal characteristic. 'The most developed were throughout the most fortunate, till the present state of affairs was reached; while the Strawberry plants which had not chanced so to develop were utterly beaten in the race of life, to the extent of becoming altogether extinct. By a like process the berries (if we may so call them,-for botanists will reprovingly tell us they are no such thing) became red, the colour serving as an advertising medium to let the fowls of the air know where the now luscious morsels were to be found.

Now I am far from saying that this is an impossible account of the growth of Strawberries-I will not even say that it is very improbable. But Mr. Grant Allen gives it simply as matter of fact, as categorically as he would tell us that Columbus discovered the New World. Is it a certain matter of fact? Are there no difficulties in the way of accepting his piece of history?

A very notable difficulty is sure to grow in the same hedgerow in the shape of a little plant, ${ }^{1}$ a Potentilla, first cousin of the Strawberry, and with a blossom so similar that it has been said, by some botanists, ${ }^{2}$ to be undistinguishable. This Potentilla differs from the Strawberry, we may say, only in this, that it has not developed in the course of its history any juiciness or edibility of receptacle. Its fruitlets-hard and indigestible as those of its cousin-remain crowded together upon a scaly and uninviting green receptacle, which no living thing finds it worth while to eat. And, strange to say, in spite of this circumstance, the plant has been

1 Potentilla Fragariastrum, or Barren Strawberry.

2 Lindley makes this assertion, which is, however, incorrect 


\section{Mr. Grant Allen's Botanical Fables}

nowise beaten in the race of life; it is just as prolific and as numerous as the Strawberry itself. Now, how is this, if the history above recounted be so indubitably the true one?

Mr. Allen sees the difficulty and undertakes to solve it. And this is his solution:" "Science cannot answer as yet. After all, these questions are still in their infancy, and we can scarcely yet do more than discover a single stray interpretation here and there. In the present case a botanist can only suggest either that the Potentilla finds its own mode of dispersion equally well adapted to its own peculiar circumstances, or else that the lucky accident, the casual combination of circumstances, which produced the first elongation of the receptacle in the Strawberry has never happened to befall its more modest kinsfolk."

But if this be true, how can the history given above be assumed as certain? If we know so little about the matter, how can we be sure that the interpretation put upon the Strawberry's characteristics is the true one? Can we be positive that it has benefited by becoming eatable, if it is not equally plain that the Potentilla has been handicapped by not becoming so? To explain away difficulties by pleading our ignorance is very well, so far as those difficulties go, but the bearings of the plea will not stop there; if we plead ignorance, we cannot claim to be heard on the score of knowledge.

In plain language, therefore, the explanation we have heard comes to this, that we know nothing about either the one plant or the other, and have to be satisfied with guess-work, more or less ingenious. It is all very good to talk about discovering an interpretation, but more accurately the process should be termed imagining.

Close to the Strawberry there will probably be found another plant which likewise furnishes Mr. Allen with a theme-the curious plant which the learned call Arum maculatum, and the unlearned "Lords and Ladies" or "Cuckoo-pint." By these names most

1 Evolutionist, p. 23. 


\section{Mr. Grant Allen's Botanical Fables 7}

people will recognize the large hooded blossom with a pink or pale-green knob in its midst, which $\mathrm{Mr}$. Allen tells us is now known to be one of the earliest flower-forms still surviving upon earth. ${ }^{1}$ Certainly, if this be so, the history which he proceeds to give of it goes to show that much development has not served to make more modern creatures a match for this crafty and malignant antediluvian vegetable.

But before we trace the grimmer features of its character, there is a question as to its fertilization on which popular writers seem now agreed, but which may afford some profitable study. Sir John Lubbock ${ }^{2}$ tells us, at great length, that it is of advantage for a blossom to have the stigmas of its pistil fertilized by pollen from another plant, and he cites the Arum as an illustration of the way in which this is brought about. This plant is monocious, that is, it has stamens and pistils in different flowers, but on the same plant. These are arranged on the lower part of the knob already mentioned, the large green hood being no part of the flower proper, but a sort of envelope and protection. On this central knobbed column are arranged, beginning from the bottom, first the pistillate, then the staminate flowers, and then a number of threadlike stalks, of which botanists a short time ago did not profess to know the meaning. Now, however, we are told-by both Mr. Grant Allen and Sir J. Lubbock-that they act as a chevaux de frise to close up the entrance of the cup in which the flowers below are placed, for these hairs point downwards, and the envelope is much contracted just about their position. Consequently, says Mr. Allen, they serve as the spikes in an eel-trap or lobster-pot.

This being so, what happens in the case of the Arum, we are told, is this. The pistillate blossoms flower first, in consequence of which the first Arum of the season must go without pollen, and therefore

${ }^{1}$ Evolutionist, p. 84.

${ }^{2}$ British Wild Flowers in relation to Insects, p. 28. 


\section{Mr. Grant Allen's Botancal Fables}

without seed for that year. But there is something in the envelope that attracts small flies, which crowd into the hood in great numbers. Getting in is easy enough, for, as has been said, the hairs in the neck bend downwards; but getting out is another matter, and the adventurous insects must wait till the opposing hairs wither. By this time the staminate flowers have bloomed, and the pollen therefrom falls on the flies and dusts their backs and legs, and when on being released they proceed to plunge straightway-despite experience-into another Arum hood, they find the pistillate flowers mature and ready to be dusted with this pollen, thus securing cross-fertilization.

This is a very pretty and interesting history: and to look at the picture of the Arum which Sir J. Lubbock engraves we should judge it to be very probable. But flowers do not always grow in the fields as they are drawn in books, and if the observer will go out for himself and find an Arum and slice it open with his penknife, he will probably find that there is nothing whatever in the chevaux de frise to hinder any fly from walking out when he likes. The threads are by no means thick set, they twist about and do not run straight, and there is generally plenty of room between their extremities and some portion of the walls. Flies there are generally in plenty, little black flies, so small that it would seem to be a matter of no consequence which way the spikes point, for they could pass between them. The real obstacle to egress is a condition which looks very much like being drunk and incapable. They lie, often many deep, at the bottom, some without any sign of life, many in a limp and languid condition, much like rioters who have broken into a wine-vault. Whether, when they come forth from their confinement, the fresh air, to which they have been so long unaccustomed, gives them strength and energy to hunt up another Arum before they get rid of their coat of pollen-and Arums do not generally grow very 


\section{Mr. Grant Allen's Botanical Fables}

near one another-is a question requiring a great deal of very close and clever observation for its solution. ${ }^{1}$

But this is somewhat of a digression. The Arum is made to tell us a story which bears remarkably on that already related by the Strawberry. The former plant is not merely "one of the earliest flower-forms now existing on the earth," but probably the most virulent specimen of plant life that exists, at least on English ground, so virulent indeed that I hope none of my readers will ever dare to masticate even a small portion of its large glossy arrow-shaped leaves. The fruits are of the quality of the plant, and these fruits turn when ripe to a rich red colour, till they form "a beautiful cluster of living coral." 2 When speaking of the Strawberry fruit, Mr. Allen tells us that "birds have quick eyes for colour, especially for red and white; and, therefore, almost all edible berries have assumed one or other of these hues."3 But, if this be true, how comes it that so very inedible a berry comes to appear in the favoured hue? Mr. Allen is at once ready with the answer. Its object, he tells us, is to attract the animal world in the shape of field-mice, squirrels, and small birds, but with treacherous intent: "For though these berries be beautiful and palatable enough, they are deadly poison. The robins and small rodents which eat them, attracted by their bright colour and pleasant taste, not only aid in dispersing them, but also die after swallowing them, and become huge manure heaps for the growth of the young plant." 4

As to which, in the first place, if this be so, how have the robins and field-mice got on in the race of life if they have developed this insensate habit of rushing like so many bulls at everything scarlet?

${ }^{1}$ Since writing the above in I882, I have convinced myself that the Arum kills the flies which visit it, and absorbs their more succulent portions into its own substance.

${ }_{2}^{2}$ Evolutionist, p. $86 . \quad{ }^{4}$ Ibid. p. p. 86. 


\section{Io Mr. Grant Allen's Botanical Fables}

The Arum is a very old-world and primitive growth. How did it so early in the history of the earth pick up what Captain Costigan would call this "aisy stratagem," which long subsequent ages of development in higher creatures have not sufficed to elude? But in the second place, is this a piece of fact or a piece of fancy? Are Arums usually, or ever, found to grow out from among the skeletons of robins or of shrews? I commend the question to the experimental zeal of my readers; the research requires only a strong knife or a small spud. ${ }^{1}$

From fruits and flowers let us turn to the leaves of plants, of which $\mathrm{Mr}$. Allen speaks in connexion with Buttercups. ${ }^{2}$ Holding up one of these familiar flowers for our perusal, he thus directs attention to the leaves: "These, one notices at once, are raised on long stalks and deeply divided into several segments. . . . Now such a complex leaf as this shows by its very nature that it must be the product of considerable previous development. All very early leaves are quite simple and rounded; it is only by slow steps that a leaf thus gets broken up into many divided segments. . . There are some other Buttercups, such as the Ivy-leaved Crowfoot, which creeps along the mud of ditches, or the Lesser Celandine, which springs in the meadows in early April, whose leaves are entire and undivided;... but both these plants, having plenty of room to spread in the unoccupied fields of spring or the unappropriated ditches, have never felt the necessity for subdivision into minute segments. They have free access to the air and sunlight, and so they can assimilate to their hearts' content the carbon of which their tissues are built up. It is otherwise, however, when similar plants push out into new situations less fully supplied. . . . The Buttercups have taken to growing in the open

${ }^{1}$ See more on this subject in the Essay, How Theories are Manufactured.

${ }^{2}$ Nature Studies, p. 99. 


\section{Mr. Grant Allen's Botanical Fables it}

meadow where the competition for vegetable foodstuffs is keen and the struggle for existence bitter. Hence they have been compelled to divide their leaves into many finger-like segments; and only those which have succeeded in doing so have managed to hold their own in the struggle, and so to hand down their peculiarities to future generations. As a rule, just in proportion as vegetation is thick and matted, do the plants of which it is composed tend to develop minutely divided and attenuated foliage."

After reading a passage like this it would seem as though, in evolutionary argument, instead of the theory being extracted from the facts, the facts are evolved from the theory. Here is a string of assertions fit to take away the breath of any one who will but go out walking and use his eyes.

Firstly. "All very early leaves are quite simple and rounded." What is meant by early? Does it mean "the earliest forms on the earth," or those which appear earliest in the year? If the first, how about grasses, which certainly are amongst the oldest forms of vegetation, but whose leaves though simple are very much the reverse of round? Or for those other forms which men of science are never weary of indicating to us as the primitive vegetation of allthe Mosses and Horse-tails - where shall we find more subdivided fronds than theirs? If, on the other hand, it be meant that early flowering plants have round leaves, where shall we find earlier flowers than the Shepherd's Purse and the Groundsel? while the Spring Crocus, which certainly has the field pretty much to itself, reduces its foliage almost to the limits of tenuity.

Next, as to the theory on which the whole argument is based. "They have been compelled to divide their leaves, ... and only those which have succeeded in so doing have managed to hold their own." How so? How does the subdivision of leaves help a plant to obtain a larger share of "vegetable food-stuffs"? It is not the edges, but the surfaces of 


\section{2 Mr. Grant Allen's Botanical Fables}

the leaves, which suck in carbonic acid through the stomata, or breathing pores, situated chiefly on the under side. It is, therefore, amount of surface that should most assist a plant to gain a livelihood in a populous and competitive neighbourhood. But, cateris paribus, surface must be proportionally greater in a simple than in a divided leaf; it should, therefore, follow that plants growing where vegetation is dense are distinguished by having their leaves not divided. Mr. Grant Allen may perhaps find in a consideration of this point an answer to the complaint he makes in another place, ${ }^{1}$ that " the problem of the shape of leaves, ... a most important one, ... has hardly been even recognized by our scientific pastors and masters."

So much for theory. Now, thirdly, for facts. "Just in proportion as vegetation is thick and matted do the plants of which it is composed tend to develop minutely divided and attenuated foliage." The Buttercup being the concrete instance in hand, apropos of which this is laid down, we may take for granted that the vegetation amidst which it is found is of the thick and matted order, and therefore let us go and view in any meadow that may be at hand the plants which press around it, and observe how far they can, as a body, be said to have divided and attenuated foliage. First there are the Sorrel and the Dock, concerning the shape of whose leaves it is hardly necessary to say anything. There is the Lady's Mantle, which by its name sufficiently indicates the form of its foliage. There are the three Plantains, all with leaves broad and entire. There is the White Saxifrage, leaves slightly lobed, the Cat's-ear and the Knap-weed, neither of them divided or attenuated. These are flowers sure to be found in any English meadow; could an equal number be named equally certain to be present which would in any degree bear out Mr. Allen's assertion about the form of leaves in such a situation?

1 Evolutionist at Large, p. 37. 
If these criticisms be true, it may, perhaps be thought that I am simply setting up a man of straw to contend with, and endeavouring to make a point against evolution by fastening on an unfavourable representative of its doctrines. But it must be remembered that Mr. Allen's sermons are delivered in somewhat high places. The papers which we are mainly considering first appeared in the St. James's Gazette, or in the rival Pall Mall. Like utterances were given forth in the journal called Knowledge - which claimed to be the newest organ of science "plainly worded, exactly described." In face of all this we cannot but take Mr. Allen as an authorized exponent of his creed, the only difference between him and others being that he treats of matters which we can more practically understand.

Enough has perhaps been given in the way of examination, more or less minute, of his various theories. It will be worth while, however briefly, to collect some specimens of the easy way in which stepping-stones are found in the deepest places to help the historian forward to the desired conclusions. Thus we are airily told - apropos of Water Crowfoot-that one of the Buttercup tribe 1 "took once, under stress of circumstances, to living pretty permanently in the water." As to the migration of Salmon: " "The ancestral fish, only a hundredth fraction in weight of its huge descendant, must have somehow acquired the habit of going seaward." The Cyclostoma ${ }^{3}$ "is a gill-breathing pond snail which has taken to living on dry land." In these and numberless other instances, what is the greatest difficulty in the matter is simply set down as a fact, and then used as a basis by means of which to explain the rest. In the last quoted instance it is frankly declared that it is "the light cast upon the question by Darwinism" which vouches for the fact being as stated. In other words Darwinism, which by way of being proved, or at least demonstrated, is taken

\section{${ }^{1}$ Evolutionist at Large, p. 42. Italics mine throughout.}

$$
2 \text { Ibid. p. } 118 . \quad 3 \text { Ibid. p. } 177 \text {. }
$$




\section{I4 Mr. Grant Allen's Botanical Fables}

for granted to start with, and, as I have already said, instead of the theory being educed from the facts, the facts are made to square with the theory.

Some very curious principles are likewise introduced which assist in the fashion of a deus ex machina over many an awkward stile. Thus, talking of the plumage of birds, we are told ${ }^{1}$ that "it is probable that an æsthetic taste for pure and dazzling hues [in the plumage of their mates] is almost confined to those creatures which, like butterflies, humming-birds, and parrots, seek their livelihood amongst beautiful fruits and flowers." Indeed! Do bees fall short of butterflies in this respect? The most beautiful beetles feed on filth; the goldfinch on thistle-seeds; the kingfisher on minnows and bull-heads.

But another question arises. If there be the alleged connexion between the colours admired in mates and those which are found in articles of food, should it not follow that those creatures which admire any particular colours in the world outside should likewise consider them additions to the beauty of their own race? And if so, how about men? Mr. Grant Allen tells us whence they acquire their appreciation of the various hues which meet their eyes:2 "The reason why we consider these colours pretty seems to me obvious. We are the descendants of ancient arboreal ancestors, who sought their food among bright orange and blue and crimson fruits in tropical forests $;^{3}$ and those fruits were specially coloured to allure their eyes, just as the speedwells and primroses and buttercups are specially coloured to allure the eyes of bee or butterfly. And further, as the eyes of the bees are so developed that these colours attract them, the eyes of our prehuman ancestors must have been so developed as to be attracted by the similar colours of oranges and mangoes, and tertiary plums or peaches."

1 Evolutionist at Large, p. 194.

2 Vignetles, p. 86.

3 See more on this subject in the Essay, How Theories are Manufactured. 


\section{Mr. Grant Allen's Botanical Fables 15}

Now if all this be meant for sober fact, should it not also be maintained that the arboreal race which was happy enough to live in a climate where such fruits hung on the trees all the year round, and in such profusion as to afford a staple article of food, should have come to regard plum colour, or black and blue, as the most becoming hue, and the most conducive to good looks among their own kind? And should not the "mulberry-faced Dictator's" have been an enviable complexion? A still more pertinent question is whether there be the slighest tittle of evidence to show that there ever was a race so sustained, except the necessity of supposing it in order to find an explanation for the colour-sense.

There is likewise a very curious piece of philosophy introduced under the ægis of Mr. Herbert Spencer, apropos of a donkey. ${ }^{1}$ This much misunderstood animal is in reality, we are told, quite an aristocrat among brutes, "one of the final developments of one of the most successful branches of the great progressive ungulate tribe." Being so high up in the social scale, he "really cannot well avoid being an extremely clever brute." But his cleverness is limited by physical conditions, and here comes in the latest addition to our philosophy on this subject: " $\mathrm{He}$ is not so clever to be sure as the higher monkeys and the elephants; for, as Mr. Herbert Spencer has pointed out, the opposable thumb and the highly mobile trunk with its tactile appendage give these creatures an exceptional chance of grasping an object all round, and so of thoroughly learning its physical properties, which has put them intellectually in the very front rank of the animal world."

Here we have a prime example of the fatal facility with which theories may be invented and presented for acceptance, theories which the most ordinary observation should serve to discredit. We are asked to believe that the power of "grasping an object all round"

1 Vignettes, p. 197. 


\section{I6 Mr. Grant Allen's Botanical Fables}

begets intelligence. Yet what creature succeeds so thoroughly in getting round an object as that stupid brute the Boa-constrictor? And how about the sagacious Dog and the cunning Fox? Neither of them embraces its prey like the slow-witted Bear. The Parrot is said by some writers, improving on Mr. Spencer, to get the intelligence displayed in its talking, because it has a prehensile foot and bill. But the Crossbill has both, yet does not learn to talk; and the Magpie, Jay, and Jackdaw have neither, yet talk not so much worse than a Parrot, and display intelligence, in other ways, far beyond his.

It would in fact be just as reasonable to maintain that animals with big tails are cleverer than those scantily furnished in that respect, citing, on the one side, the Beaver, Fox, Magpie, and Collie Dog, and on the other the Guinea-pig, the Mole, and the Bat.

Mr. Allen sets his face with much determination against the idea that there is any intentional beauty in the universe; there is, in fact, no beauty in anything at all till it is "read in by the fancy of the human race." I In a sense we need not very much quarrel with this, but evidently that sense is not his. What he means is that there is no sort of relation between the beauty we find in nature and the faculty by which we recognize it; that the thing which we feel to be beautiful, and the perception of its beauty within ourselves, equally come to exist in a blundering haphazard fashion quite independently the one of the other. The subject is too large and too deep a one to be attempted here in any fulness; it will suffice to set forth one of Mr. Allen's notices of it, leaving it to speak for itself. He is talking of the flower of the Lesser Bindweed : ${ }^{2}$ " Nothing could be prettier than this alternation of dark and light belts; but how was it produced? Merely thus: The Convolvulus blossom in the bud is twisted, and the bits of the blossom which are

I Evolutionist, p. I99.

2 Evolutionist, p. 200. The italics are mine. 
outermost become more deeply oxidized than the other parts, and acquire a russet-red hue. The belted appearance which thus results is really as accidental, if I may use that unphilosophical expression, as the belted appearance of an old umbrella. The flower happened to be folded so and got coloured, or discoloured, accordingly. ... Four or five petals radially arranged in themselves produce that kind of symmetry which man, with his intellectual love for order and definite patterns, always finds beautiful. But the symmetry in the flower simply results from the fact that a single whorl of leaves has grown into this particular shape, while other whorls have grown into other shapes, and every such whorl always and necessarily presents us with an example of the kind of symmetry which we so much admire. ... Thus the whole loveliness of flowers is in the last resort dependent upon all kinds of accidental causes-causes, that is to say, into which the deliberate design of the production of beautiful effects does not enter."

Here is surely a key to many difficulties, and an antidote to much misplaced admiration. Let the reader remember next time he may chance to visit a printworks that the figures impressed on the calico are but a necessary result of the machinery: given that the rollers rotate, and that the stuff passes under them, the distribution of reds and blacks and yellows in the forms we see, follows as a matter of course. It is moreover to be remarked that the Bindweed is frequently destitute of these dark bands, though in bud it has been folded as described.

There are many tempting themes to which Mr. Allen invites us, and not least when he decides concerning the Butterfly that it is "mainly an animated puppet," but yet "a puppet which, after its vague little fashion, thinks and feels very much as we do."1 Into these themes, however, I cannot now follow him, but before parting company I would try a specimen of his method on my own account, and, going out into the fields, look to see ${ }^{1}$ Evolutionist, p. 160 . Italics mine. 


\section{I8 Mr. Grant Allen's Botanical Fables}

whether there be not evolutionary difficulties as well as evolutionary arguments to be found there.

First, let us look up to the tops of the elms, where the Rooks are as I write so busy with their nests. How came they to develop their nest-building faculty? These large conspicuous structures must be placed on the tops of trees to be safe. The first building of them must have been in such a position. But if the ancestral rook had tried the experiment of establishing his household gods there before he had acquired the present architectural skill-would any young rook have survived to carry his dusky race down to the present day? To build dry unbendable sticks into a nest on a windy tree-top would seem to be but to prepare for it the fate of the historic cradle placed in a like position. I much doubt if, without the aid of twine, the cleverest man living, although in possession of an opposable thumb - as to which gift alone Mr. Grant Allen seems to say ${ }^{1}$ have his ancestors behaved better to him than those of a donkey-could with such materials construct a nest which should withstand the gentlest breeze, let alone a south-western gale.

This is, at least, something of a problem. If from the tree-tops we turn our eyes down to the waters under the earth, we shall meet with another. How come the backs of fishes so closely to resemble the surface above which these fish live? How, to take particular examples, does the Loach come so exactly to mimic the stones at the bottom of the brook, or the Skate and Flounder, as we see in aquariums, the gravel or sand on which they respectively dwell? It is not enough to say that "nature" enables them for protective purposes thus to hide themselves. Take a dozen, or a score, or a hundred fish, and in no two are the markings the same; there is every variety of detail, but one general effect of resemblance to the common object, just as in a long gallery of deal doors which a skilful

1 Vignettes from Nature, p. 93. 


\section{Mr. Grant Allen's Botanical Fables I9}

grainer has converted into the semblance of oak. Now, how can there be implanted in a nature, by any blind and accidental forces, a tendency simply to resemble gravel or mud? We might possibly conceive every fish being so provided with a black or red spot in one unvarying position, but where there is this strange evidence of an indefinite and yet artistic purpose do we not come face to face with what Mr. Grant Allen would deny, "the deliberate design of the production of effects?"

I have said that here I will conclude, at least for the present. A large and tempting field yet remains unvisited - the question of the colour of flowers, concerning which Mr. Allen says something and Sir John Lubbock much. But this subject, if attempted at all, would demand an entire paper to itself, ${ }^{1}$ and should be treated with an amount of detail which, at present, I wish to avoid. My object is but to show how evolutionary argument looks when it condescends to come down to a field in which we can experiment for ourselves, and of what texture are the argumentative products of that modern exact thought which we are daily told to regard as putting to shame the loose reasonings of our undeveloped ancestors.

Theories and hypotheses have their place, and a most valuable place it is, in the field of scientific knowledge, and undoubtedly we do well to feel our way by means of them to the solution of problems which older generations never attempted. But we outrage science and bar the road to sound knowledge if we take as proved and certain what is as yet but hypothetical and speculative; and if, through a natural partiality for a system of our own, we get ourselves into the way of forcing facts to fit into it, whether they will or no, or neglect those which tell against it, having no eyes to see anything but what seems to bear witness in its favour.

Of all this there seems to be only too much danger. We are in such desperate haste to assure ourselves ${ }^{1}$ See the Essay, Who painted the Flowers? 


\section{Mr. Grant Allen's Botanical Fables}

that we have sounded the bottom of all knowledge, that we cannot be content to acknowledge our ignorance, even when our ignorance is the truth. Hence, instead of patiently and dispassionately garnering the facts and sifting them, to see what they will yield, writers too frequently start with an assurance that they know the issue before they examine the record, and with an indignation against those who deny their theory which would be righteous if that theory were already demonstrated, but which is thoroughly unscientific if Darwinism is still beset by a multitude of scientific difficulties. Is it not far more wise to say that we do not yet know, as in fact we do not, than to amuse ourselves with imaginary histories, and giving them to the world as contributions to its knowledge? 


\section{raho painted the jlowers?}

IT may, I suppose, be without question assumed that flowers are beautiful. Whatever else the caprice of taste may command us or forbid us to admire, there is one fashion which, though every season repeated, is yet found to be ever fresh-the fashion of the Violet and the Rose; and there is no truth to which the common observation and the common-sense of mankind have given a readier assent, than they have to the declaration that the most splendid of monarchs in all his glory was not arrayed as are the lilies of the field.

So far there is agreement. But in these days of ours it will not do to rest satisfied with the fact: it must needs be asked how the fact came to be. That these beautiful flowers were made beautiful, simply as they are, that their gracefulness came to them as it comes to a copy of themselves on a Christmas card or in an artificial bouquet, directly from the hand of an artist, is not the sort of explanation of which contemporary science will take account. But as the fact has to be somehow explained, science is ready to explain it, and that particular school of science for which there are no puzzles, for which the making of an apple is an operation nowise more mysterious than the making of an apple-dumpling, is here, as everywhere, ready with a full, true, and particular account of the process of their adornment and of every step and stage in the same. As usual, too, the explanation offered is not likely to err through any morbid deference towards the ideas of previous generations. It has hitherto been supposed that flowers are not only the most beautiful but also the II. 
least utilitarian of the products of the earth; that their chief function is not in any way to toil or to spin, but to adorn our fields and woods with the brightness of their hues and the fragrance of their breath, and that in the need of some such adornment to save the face of nature from too dull a monotony, is somehow to be sought the reason of their being.

This, we now learn, is all wrong. The colours on the petals of a Rose are no more to be attributed to a purely artistic motive than those on the sign-board of an enterprising publican. Flowers are in fact like nothing so much as sign-boards, which let the passing insect know where good cheer, in the shape of honey, is to be had; and the blossoms which we see at the present day are what they are simply because they have managed their advertising business better than others, which they have consequently trampled out of the world in the keen competition for existence.

This is no overstatement of the theory in vogue. Flowers, it is said, need the service of insects to assist in their propagation, and therefore must attract insects, and those which have best succeeded in so doing have best succeeded in the race of life. And consequently the various hues and their various arrangements which we see in blossoms have come to be there because their casual presence helped in the great work of attraction, and therefore they were, by natural selection, "developed." Hear Sir John Lubbock : " To them [the bees] we owe the beauty of our gardens, the sweetness of our fields. To them flowers are indebted for their scent and colour; nay, for their very existence, in its present form. Not only have the present shape and outlines, the brilliant colours, the sweet scent, and the honey of flowers, been gradually developed through the unconscious selection exercised by insects; but the very arrangement of the colours, the circular bands and radiating lines, the form, size, and position of the petals,

${ }^{1}$ British Wild Flowers in Relation to Insects, p. 45. 
the relative situations of the stamen and pistil, are all arranged with reference to the visits of insects, and in such a manner as to ensure the grand object which these visits are destined to effect."

The expression "unconscious selection" here employed suggests a question which Sir John Lubbock does not explicitly propose, and which, though I do not purpose to treat it, should at least be indicated. Of course the selection, whatever it be, exercised by insects must, so far as they are concerned, be "unconscious." But when that is allowed the question of design remains in its entirety. Are these unconscious workers, or are they not, the instruments of conscious intelligence? Many, especially among the lesser lights, of the modern school are very peremptory in their denial of any consciousness, or intelligence, or æsthetic intention, anywhere in the process of evolution. Mr. Grant Allen, for example, tells us ${ }^{1}$ that "the whole loveliness of flowers is ... dependent upon all kinds of accidental causes - causes, that is to say, into which the deliberate design of the production of beautiful effects did not enter as a distinct factor." The question so raised I do not now wish to treat. It appears to me that to institute an argument on this point would be very like insisting that we could not get a finished picture of the Venetian school by shaking a kaleidoscope; nor produce a poem of Tennyson's, say the In Memoriam, from the letters which designate the divisions of our police, by arranging the men who compose the force along Regent Street, according to their height or their weight or their length of service. It is true that an eminent leader of fashionable thought ${ }^{2}$ finds the existence of a Providence a less satisfactory and scientific explanation of the phenomena we observe than an "unconscious effort to the good and the true which exists in the universe, and throws a cast of the dice through each of us." But such phrases are,

1 Evolutionist at Large, p. 205. 2 M. Renan, Souvenirs d" Enfance et de Jeunesse. 
at least to the majority of minds, to say nothing of their authors, simply phrases, and mean nothing. "Some people," says Dr. Asa Gray, "conceive of unconscious purpose. This to most minds, seems like conceiving of white blackness." It must needs be a hyper-metaphysical disquisition which has such a concept for a theme, and I wish to deal not with speculative, but with observed fact. Supposing the production of beauty to be like everything else in nature, the result of law, ${ }^{2}$ I wish to ask how far the facts that we can see bear out the theory that insects have been even the sole instruments for the production of beauty in our gardens and our fields. This is a pure question of natural science, which can be discussed without any a priori prepossessions. To allow the insects all that is claimed for them would not be to deny that there is a law : it would be to make the law inconceivably more wonderful. The checks and counter-checks of the system must be indeed of marvellous complexity, if insects working directly for food, and indirectly serving to the propagation of species, and being allured by colour as an indication of food, and so serving more indirectly to propagate colour, should under the guidance of one unvarying taste have produced, in respect of colour, such bewildering variety, and through all variety have in every direction hit upon the beautiful: wonderful indeed would it be that not only they should have dyed different blossoms with all the different colours of the rainbow, but that they should have managed these different materials with such exquisite diversity; spotting the Foxglove, and streaking the Iris, and yet refraining from painting the Lily, - while yet in each case the result has been such that we can conceive none fitter.

As a plain matter of fact then, how does the observa-

1 Contemporary Review, April, 1882, p. 609.

2 "Lawless, or really random variation, would be a strange anomaly in this world of law, and a singular conclusion to be reached by those who insist upon the universality of natural law" (Dr. Asa Gray, loc. cit.). 
tion which is within the reach of all bear out the assertion that all which there is in flowers is "arranged with reference to the visits of insects, and in such a manner as to ensure the grand object which these visits are destined to effect"? 1

The theory, I repeat, is that every variation which has been perpetuated has been so perpetuated because it served to attract insects, which have in their turn served to propagate the variety. But, in the first place, if this be true of colour, how about form? This is a most important factor in the beauty of flowers. "Everybody knows," writes Mr. Grant Allen, " "that flowers are rendered beautiful by their shapes, by their perfumes, and above all by their colours." And Sir John Lubbock, in the passage already cited, includes "the shape and outlines "among the features which have been developed through the selection of insects. But how can the form conduce, or be imagined to conduce, to the advertisement of honey-stores within? In a broad way, certain shapes of blossoms may help a bee or a butterfly to find where the honey is more readily, or to get at it more easily. But, to say nothing of such fantastic growths as the Butterfly Orchis or the Monk'shood, how can the artistic finish of the edge of a petal or the curve of grace and beauty introduced in the outline of a cup do anything to allure honey-seekers? Or, letting the flowers alone, how can this agency account for the graceful shapes of leaves?

Moreover, there is a large class of plants which admittedly owe nothing to insects, - the anemophilous or wind-fertilized flowers, and the large order of Cryptogams, -ferns, mosses, and the like. It is generally assumed on the utilitarian hypothesis that where colour can do no positive good it cannot exist, and that its absence, in the case of the plants indicated, is 2 proof of the general

${ }^{1}$ Dr. Asa Gray pertinently remarks that all writers have to agree in speaking of "arrangements," "adaptations," "contrivances," and the like, in this connexion.

${ }^{2}$ The Colours of Flowers, p. $x$.

II.* 
theory. But firstly, it is by no means true that colour is absent. The hues of our autumnal fungi are at least as vivid as those of any spring or summer blossoms, and in the large wind-fertilized tribe of the grasses there is great variety and great beauty of colouring, as one may see in any meadow in May or June. But beyond that, and granting for the sake of argument the absence of colour, who can deny the exceeding great beauty of the fronds of a maiden-hair fern or the head of a feathergrass? Mr Ruskin's exquisite little engraving of "foreground leafage" in Modern Painters fills many with wonder and delight, and yet, as he himself tells us, it represents only what any one may see who chooses to lie down on his face in a field in summer; while in any square yard of vegetation there are more delicate variations on the same theme than any artist but the sun can faithfully reproduce.

Here then is, at the outset, a difficulty which seems fatal to the theory under examination; for if there be undoubted facts which the agency of insects can nowise have affected, how can it be assumed that such agency is the only possible explanation of other facts analogous to these?

Leaving this question suggested by the shape, I come to the colour itself. How far is the theory of insect agency supported by a mere examination of this element of flower beauty prescinding from aught else? That insects, bees especially, can produce very marked variegation in the colour of blossoms, no one will deny who has seen the growth of a zebra-like variety of garden Nasturtium (Tropceolum majus) after the bees have been busily working alternately at a bed of maroon-brown and of sulphur-yellow flowers. But how far are we justified in assuming that this has been the sole means of producing the colours that we see? Those who defend such a position assert, as is indeed necessary for their case, that all flowers with conspicuous petals miust depend on insects for their well-being, otherwise they would but waste so much of their vital energy on an 
unremunerative product. So assured are they of this, that Mr. Grant Allen, relying on an a priori method of reasoning which would seem rather out of harmony with modern scientific canons, unhesitatingly pronounces on the past history of plants from this feature alone. There is, for instance, a well-known plant, the Ribwort Plantain (Plantago lanceolata), with which children play at "soldiers"-if indeed there still be children who care to play games which cost no money. It is windfertilized and unvisited by insects. At the same time it has a perfectly-formed corolla-inconspicuous indeed, dark-coloured and dry, but as symmetrical in form as a corolla need be. A wind-fertilized plant has no need of a corolla at all, and can gain nothing by turning out on every one of its flower-heads a multitude of these shapely little cups. Therefore, says Mr. Allen, the Plantain is a degraded plant; it was once fertilized by insects, but has for some reason or other reverted to the "older and more wasteful process" of wind-fertilization, retaining, however, in its little corolla a testimony against itself. "Once upon a time it was a sort of distant cousin to the Speedwell. But these particular Speedwells gave up devoting themselves to insects, and became adapted to wind-fertilization. ... Thus every plant bears upon its very face the history of its whole previous development." I We are accordingly asked to take it for granted with the same authority, ${ }^{2}$ that the bright pigments of flowers have for their main, if not their only function, the attraction of insects - from which it would follow that a bright flower with no honey, or a bright flower, at which, from any circumstance, insects could not get, would be a monstrosity in nature, and would as such be necessarily and speedily trampled out. It is at least remarkable that what is probably the most conspicuously-coloured of English flowers, the Poppy, secretes no honey at all, although it is true that its abundant pollen offers some reward to the bees

\section{${ }^{1}$ Evolutionist at Large, pp. 137-I41. ${ }^{2}$ Colours of Flowers, p. 7.}


which take the trouble to visit it, which special source of attraction will suggest another question presently. But a far more puzzling problem is presented by Wordsworth's pet flower, the Lesser Celandine (Ranunculus Ficaria). Appearing in early spring, when insects have hardly begun to stir, this little plant indulges in a luxuriance of blossomhood not inferior to that of its cousins, the summer Buttercups. That from a decorative and æsthetic point of view such display is worth making, no one will deny who looks forward, as one of the chief charms of spring, to see the Celandines "take the winds of March with beauty." But as a mere matter of business, where does the plant find its account for all this expenditure? Not certainly in its fertilization by insects, which is sufficiently evidenced by the fact that Celandines are seldom fertilized at all. The examination of a whole field after flowering will hardly result in the discovery of a single ripened head. Yet the Celandine contrives to increase and multiply, and that by a process which not only emphasizes the difficulty already started, but seems to strike a blow at the very root of the whole insect theory.

The main principle on which the need of insect agency is supposed to rest is the necessity for crossfertilization. The ovules of a plant, it is said, should for full development be impregnated by pollen from another plant of the same species, and insects afford the surest means of securing this. Now, without doubt, cross-fertilization is often highly advantageous. But is it universally, or quasi-universally, necessary? To judge by the utterances of some men of science, we should suppose so. "Nature," says Mr. Darwin, "abhors perpetual self-fertilization." I "I will not enter," says Sir John Lubbock, ${ }^{2}$ " into the large question why crossfertilization should be an advantage, but that it is so has been clearly proved." And the whole gist of the 
literature on this side of the question is summed up by Dr. Asa Gray in the proposition "that all the various adaptations of flowers to insects are in view of intercrossing." It is assumed, in fact, that by a timely deference to nature's "abhorrence," those plants which have secured cross-fertilization have produced a vigorous progeny which has stamped out the effete rivals which failed to avoid a contradiction of the fundamental law "No continuously self-fertilized species would continue to exist," is an aphorism of the school. But the Celandine is a vigorous growth, making fields yellow with its useless cups, and with no mark of approaching extinction upon it. And how, failing its blossoms, does it contrive to propagate? Simply thus. In the axils of its leaves there form little proliferous bulbs, which in due season, dropping off, become the parents of new plants. This is the very contrary of crossing. For a cross, such as is postulated, two distinct plants should contribute to produce a new one, and here there is not the contribution even of two distinct organs. And this is by no means a solitary case : propagation on the same principle is adopted by very large classes of plants. Sometimes it is by runners rooting at the joints (of which the Strawberry affords a familiar instance), sometimes by suckers, sometimes by buds, or by slips and shoots. And such plants are propagated in endless abundance. It has, for example, been said that all the Weeping Willows we see have probably been produced by slips from one common ancestor, for the willow is dicecious (bearing stamens and pistils on different trees), and there is no staminate Weeping Willow known in Britain, and consequently the tree never fruits $;^{2}$ while, as is well known, all our cultivated Apples are propagated by grafting, each variety carrying on through all its members the life of one individual ancestor. Some of these varieties (for instance, the Herefordshire "Red

${ }_{1}^{1} \mathrm{Ibid}$. p. 600.

${ }^{2} \mathrm{~A}$ large number of the trees of this species have been propagated from Napoleon's Willow at St. Helena. 
streak" and "Fox whelp") are known to have existed for nearly three centuries. Indeed, so far from being unduly handicapped in the race by their utter neglect of the fundamental law, these self-propagating plants are precisely the most rampant and aggressive of all, and the most difficult to get rid of.

For instance, the Creeping Buttercup (Ranunculus repens) is designated "a troublesome weed" because it increases by creeping roots or scions, which take root wherever a leaf is produced; the Coltsfoot (Tussilago Farfara) is almost ineradicable, because any fragment of its long and brittle roots serves to produce a new plant; and a variety of the Lady's Smock (Cardamine pratensis) merits the designation "remarkably proliferous" because, while its flowers become incapable of fertilization, owing to doubling, the leaflets as they come to the ground produce fresh plants.

There seem, therefore, to be facts, on the very threshold of the inquiry, which may at least justify us in pausing before we accept the doctrine which is so unhesitatingly laid down.

But the most interesting portion of my task will consist in an examination of the case made out by the advocates for the insects. Before undertaking such examination of some facts of this case, which will raise some new points as well as some of those already noticed, it will be well to state precisely once again what is my contention. I do not at all wish to deny that insects are of service to flowers, nor, this being so, that there are many "arrangements" on both sides to secure that the service be effectually rendered. But given a fact, many modern writers are far too prone to found on it an hypothesis which depends far more on an a priori conception of the fitness of things than on the fact with which it is thought to square. The hypothesis once stated is then far too often itself treated as a fact, and it is sought to make out a case for it by quoting other facts which seem to bear it out. The making out of such a case is not difficult, and is apt, quite unin- 
tentionally, to become a mere piece of special pleading. It is very easy to collect all the instances that tell one way, and to forget those which tell the other way: it is easy for a man who has too hastily assumed the truth of his hypothesis to see all facts through its medium, and to make them mean something which on more critical examination would be seen not to be their meaning. It seems to me that a conspicuous example of such a process is afforded here, when from the undoubted usefulness of insects to some flowers it has been inferred that all flowers have been entirely modified by insects in all those respects which bring them into connexion. It seems also that even so earnest and so painstaking an investigator as Sir John Lubbock has not escaped the danger above indicated, and has in many instances seen his facts with pre-determined eyes.

In his work, British Wild Flowers in their Relation to Insects, from which I have already quoted the general conclusion which he seeks to draw, he runs through the whole British flora, and endeavours in the case of each family to establish the truth of his hypothesis. It seems truer to say that we need go no further than his book to find convincing proof that insects can not do all that is claimed for them. It is not easy to arrange in very logical order the points which arise from the examination of many separate examples. Having indicated my general drift, I shall consider it enough to arrange my strictures very much in the order which his work suggests.

He tells us, ${ }^{1}$ with regard to anemophilous, or windfertilized flowers, that "it is an advantage to these plants to flower before the leaves are out, because the latter would greatly interfere with the access of the pollen to the female flower." Now it is true that Hazels, Poplars, and the like, flower before the leaves appear, and that they are wind-fertilized; but no less so

$$
2 \text { op. cit. p. } 8 \text {. }
$$


do the Wild Cherry and other entomophilous, or insectfertilized, trees. Again, the large class of the Coniferce, the Fir tribe, are evergreen, with one exception, the Larch. The Larch is also the one which is not windfertilized. In the case of all the others, Scotch Fir, Yew, Spruce, for instance, the flowers cannot possibly appear before the foliage.

"Again," says Sir John, "in such [wind-fertilized] flowers, the filaments of the stamens are generally long ;" but again, I would remark, in the Scotch Fir and the Yew there are no filaments at all.

Some woodcuts are given by Sir John to show how the stigma ${ }^{1}$ in wind-fertilized flowers is more branched and hairy than in those fertilized by insects. No doubt, it is obvious that such an arrangement is but natural and to be expected; but it is dangerous to deduce general rules from particular facts, and if the examples were somewhat differently selected, the conclusion would not be so clear. If, for example, the Apple or the Water-Plantain (Alisma Plantago) were chosen to represent the entomophilous, and the Ash the anemophilous plants, it might seem that the rule was reversed.

But these are minor matters, and are valuable only as showing how easy and how unsafe it is to generalize. To come now to the main point at issue, which resolves itself into two questions. (1) How far does it appear proved that the sole function of colour in flowers is to attract insects? (2) How far, that the service of insects is the main advantage to plants in the struggle for existence?

As to the first question, Sir John Lubbock implies ${ }^{2}$ that even in the case of two species of the same genus, the larger or more showy flower will attract the more numerous insects. But how does the theory so implied agree with the fact that many of the most insect-

1 The summit of the pistil on which pollen from the stamens has to be deposited for fertilization.

2 P. 4 I. 


\section{Who painted the Flowers?}

frequented flowers are the least conspicuous? Mignonette, for example: it is hard to conceive a flower offering less in the way of show, and certainly none is a greater favourite with bees. Again, many intelligent people might be in the habit of seeing trees all their lives, and yet never advert to the fact that the Sycamore and the Lime bear flowers at all-so unobtrusive are they. Yet these flowers are prime favourites with bees. If it be said that the size of the trees renders coloration unnecessary, how, I would ask, can such a position be maintained? Amid so many other trees which produce no honey, surely a guiding mark ought to be as essential as in the case of blossoms in a field. How, again, account for the fact that so many large trees $d o$ produce conspicuous flowers - for example, the Horse-Chestnut and the Hawthorn? Again, though it be true that the Lime and the Mignonette bear sweet-smelling flowers, yet the Sycamore, whose flowers are the least conspicuous, is comparatively scentless, while the Lily, for example, and the Violet, are both showy and odoriferous.

Moreover, as there are colourless flowers that attract insects, so there are brilliant flowers which contain no honey. An instance has been already quoted, namely, the Poppy; which, however, we are told insects visit for the sake of the pollen. But how, in such a case, can their visits produce cross-fertilization? Either in such a flower the stamen and the pistil mature sinultaneously, or they do not. If simultaneously, the flower can fertilize itself, and an insect visiting it is as likely to dust the stigma with pollen from its own stamens as with that from others. If, on the other hand, the stamens are mature when the pistil is closed, insects will visit the flowers (seeking the pollen of the stamens) only when the pistil is incapable of fertilization.

But Sir J. Lubbock tells us that in some such instances the colours serve as a sort of ignis fatuus to lure insects on a bootless errand. Thus, of the St. John's 
Worts ${ }^{1}$ he says: "They secrete no honey, but are frequently visited by insects, partly for the sake of the pollen, partly, perhaps, in a vain search for honey." And of the Restharrow, "Ononis does not secrete honey, ... [it] is exclusively fertilized by bees, and H. Müller has repeatedly seen male bees visiting this species in a vain search for honey." 2

Now on development principles this should not be. Not only have flowers been so modified as to get the best service from bees, but bees have in their turn been made fit to drive the best possible bargain with flowers. "If flowers," says Sir John Lubbock, ${ }^{3}$ "have been modified with reference to the visits of insects, insects also have in some cases been gradually modified, so as to profit by their visits to flowers. This is specially the case with reference to . . . bees and butterflies." And Mr. Grant Allen ${ }^{4}$ lays down that "the eyes of the bees are so developed" as to be attracted by the colour which flowers display. But if they are so developed it surely should follow that they have by this time come to know the colours which signify "no honey" as well as those which give token of much. The Restharrow, for example, is a flower of very peculiar hue, one that can be distinguished by a human eye at a considerable distance. Bees should have by this time learnt that this particular colour means "Honey-seekers, apply elsewhere!"

But not satisfied with the general assertion that colour serves only to advertise and attract, Sir John Lubbock goes to declare that the actual disposition of the colours is obviously regulated by the same conditions: "the very arrangement of the colours, the circular bands and radiating lines .... are all arranged with reference to the visits of insects." In other words, we are asked to believe that the varieties of colour are always only nature's finger-posts indicating to the visitor where is the store of which he is in quest.

$$
\begin{aligned}
& 1 \text { P. 69. } \quad 2 \text { P. } 84 . \quad 3 \text { P. 12, } \\
& 4 \text { Vignettes from Nature, p. } 86 \text {, }
\end{aligned}
$$




\section{Who painted the Flowers?}

But how can such an explanation meet the case of colours on the outside of a flower? And many flowers are painted on the back of their petals as well as on the face, while some, as the Apple-blossom, are painted on the back and not on the front. Mr. Grant Allen gets out of this last difficulty by quietly remarking that the colour has not yet developed to the other side. ${ }^{1}$ But if it is useless where it is, how does it survive to develop at all?

Again, the same author points out that it is irregular flowers which are variegated, ${ }^{2}$ while regular forms (in the case, at least, of wild flowers) are almost always of uniform hue. But if honey-clues were necessary in the case of any flowers, it would be precisely in these latter and not in the former. The difference between a regular and irregular blossom is that between a saucer and cream-jug. In the first there might be some possible difficulty in finding a patch of honey, but in the latter the shape tells the story; it must be at the bottom. As Sir J. Lubbock himself says, ${ }^{3}$ "The advantage of the irregularity [of shape] is that it compels the insects to visit the nectary in one particular manner." An insect which does not know that it has to crawl down a Foxglove-bell to get what it wants is hardly likely to be conducted to it by an observation of the faint and irregular spots which are scattered beneath its feet. It should be noted, too, that in some flowers (as in the Pinks) the colour-bands run transversely to the course of honey-seeker, and so can do nothing in the way of guidance, while in others, as in Milkwort (Polygala), where the sepals are the conspicuous part, and are quite as clearly veined as the petals of a Geranium, a pursuit of the colour indications would lead to the place where the honey is not.

With regard to these honey-clues, has the experiment ever been tried of painting false ones on a flower? If so, has any insect ever been misled? If not, does any
1 Colours of Flowers, p. 25.
${ }^{2}$ P. 6r.
${ }^{3}$ P. 8 o. 
observer conceive that there would be the smallest hope of misleading it? For it must ever be remembered that insects show in the plainest manner that they are dependent on no such adventitious guidance. In many cases (as for example, Columbine, Tufted-Vetch (Vicia Cracca), and Oxlip), bees find it most convenient to get at the honey by biting a hole through the corolla from the outside, without troubling themselves to thrust their trunks down the tube. Now, if they can thus tell the position of the store when an opaque veil intervenes, what possible reason is there for supposing they need the guidance of spots and lines when advancing down a tube?

So much for the idea that the colours of flowers are designed solely for the allurement and guidance of insects. Next, how far does their service, even when secured, appear to be the great benefit which it is assumed to be? Here, again, I limit myself to facts for which Sir John Lubbock speaks.

In the first place, the great order of the Cruciferce, a remarkably vigorous and thriving tribe of plants, is thus described by him: ${ }^{1}$ "But although the colour, honey, and scent of the Cruciferce have evident reference to the visits of insects, this order does not offer so many special and specific adaptations as we shall meet with in other groups; and the majority of species, at any rate, appear to have retained the power of self-fertilization;" whence it appears that the retention of such power is, after all, no great hindrance in the struggle for life.

Again, the Lime-tree, as I have said, is a prime favourite with bees. Yet what is the result? Sir John Lubbock ${ }^{2}$ again tells us: "The visits of insects are very numerous, and yet in this country the Lime seldom produces ripe seed." What argument do we therefore find to warrant us in declaring that the only object of all its pomp of blossom is to attract visitors which benefit it nothing? 
Finally, not to multiply instances, I take the case of the Violet. This produces two kinds of flowers; one, in spring, the well-known odoriferous and handsome blossom which is visited by bees: the other in late summer, minute, inconspicuous, with neither scent nor show, and unvisited by insects. Yet it is the latter kind and not the former which produces the bulk of seed; " in fact," says Sir John Lubbock, "the Pansy is the only one of our English species [out of five] in which the showy flowers generally produce seed." I The fact speaks for itself. Sir John can only suggest that the showy flowers are useful "in securing an occasional cross."

Such theoretical suggestions are one thing: the laying down of a dogmatic proposition, like that quoted at starting, is quite another : and enough has, I think, been by this time said to show that the facts in our possession do not by any means warrant such dogmatism. ${ }^{2}$

If this be so, and if even so careful and observant an author has allowed himself to be hurried too fast by the exigencies of theory, it is scarcely necessary to dwell on the more extreme views of less scientific writers. Mr. Grant Allen, for instance, draws out a chromatic scale of the likings of bees. Their favourite colour, he tells us $^{3}$ is blue. "Blue flowers are, as a rule, specialized for fertilization by bees, and bees therefore prefer this colour ; while conversely the flowers have at the same time become blue because that was the colour which the bees prefer." This, if it means anything, means that blue flowers contain more honey than others; otherwise the bees would be credited with a taste in colours for their own sake, which would at once destroy the utilitarian theory and bring the coloration question back to the

1 P. 58.

2 Plants growing in meadows where they are liable to be cut down, as the Lady's Mantle and Mouse-ear Chickweed, have likewise adopted this device of producing cleistogamous, or inconspicuous, blossoms.

${ }^{3}$ Colours of Flowers, p. 19. 
ground of æstheticism. Can it then be said that blue flowers are pre-eminently honey-bearing? It would be hard to know what blue flowers could be meant. In a rolling sea of blue Hyacinths we shall not find as many bees at work as in the inconspicuous green tassels of the Sycamore overhead; while the Heather and Mignonette will certainly compare not unfavourably with the Speedwell and Harebell, and even with the Sage and other labiates, "perhaps the most specialized of any flowers so far as regards insect fertilization." 1

In view of these instances, therefore, and of many others such as these, I maintain that the insect theory is, to say the least, not proven. And if we turn to some considerations of a more general nature, its position will certainly not be improved.

In the first place, even supposing, for the sake of argument, that all development in flowers of colour and form and nectaries has been produced by the agency of insects, yet for development we need the thing to be developed : and whence came that? Granted that the bees painted the flowers, who supplied the paints ? A pink blush, it is said, appearing on the petal of a rose made it more attractive than it was when pure white, and so the pink blush was gradually developed to crimson. But whence the pink blush? The bees did not make that. And whence its power of developing to crimson? All the bees in the world could not develop an agate into a ruby. And therefore there must be something for which they are not responsible, and that something the

${ }^{1}$ It is remarkable to what length the imperious demands of theory will go, and how far one theory will prove inconvenient to another. In his essay on the colour of flowers, wherein he traces the process of development according to this indication alone, or at any rate chiefly, Mr. Allen comes to the conclusion ( $p .32$ ) that the Ranunculacea, or Buttercup family, are the most primitive of all dicotyledons and "perhaps best of all, preserve for us the original features of the early dicotyledonous flowers." Yet it is precisely the Ranunculacea which botanists who judge by structure have unanimously set down as the most developed of all dicotyledons, that is as the furthest removed from monocotyledons. 
most important of all. As Dr. Asa Gray well says, ${ }^{1}$ "The origination is the essential thing. . . . To be a scientific explanation [the theory] should show, or enable us to conceive, how insect-visitation operates or in any way tends to develop colours, and originate apparatus. ... Thus far it does not appear how the visits of bees to a blossom can make one hair white or black. For all that yet appears, we may be indebted to bees for the beauty of our gardens and the sweetness of our fields, much as we are indebted to the postman for our letters. Correspondence would flag and fail without him; but the instrument is not the author of the correspondence."

It seems obvious, then, that if flowers had been developed by bees, it is because it was their nature to be so developed: and that nature was theirs before the bees came. What development there has been must have been along lines already laid down when the flowers were made. The beauty which has resulted cannot be attributed to the labourers who educed it, unless we are prepared to credit the masons and carpenters with the artistic merit of a cathedral.

Another question which suggests itself refers to the doctrine of development itself upon which the whole argument depends. With regard to that doctrine, I must for my own part say that in the observation of facts within reach I meet with more apparently insoluble difficulties than with fragments of proof. It is generally assumed that the alternative to the development theory, the supposition, namely, that all members of one species are descended from one common ancestor originally created in that form, is too violent to be entertained, and that on development principles the difficulty disappears. But, I would ask, must not developists suppose that all these individuals are descended from one common ancestor originally developed to this form? Otherwise, if there had been independent developments, how account for the marvellous identity of results? How, at least

1 Contemporary Review, ut supra, p. 606. 
without allowing the reality of an energetic law which would put accident out of the question. Take, for example, so familiar a weed as the common Dandelion. ${ }^{1}$ This is a composite flower, and as such must have been much developed. Its individuals, as in the case of all species, agree one with another in a number of most delicate particulars, as all may see by reading the description I append. ${ }^{2}$ Is it to be said that all the Dandelions now growing are descended from one original that had changed into the present form? If so, the difficulty is practically as great as under the non-development supposition. If not, -if different lines of individuals have all developed into agreement in all these particulars - the difficulty seems much greater : and greatest of all on the insect theory. The Dandelion has an enormous geographical range : it is found in the Arctic regions, in all north temperate regions, and, moreover, in the temperate regions of the southern hemisphere. The insect visitors in Greenland, in China, in Italy, and in Patagonia can hardly be alike; how, then, is there such complete, I will not say similarity, but identity of result? How indeed, except by allowing that the insects were, at the very most, but instruments, and that the Dandelion, as we see it, was designed from the beginning?

Another remarkable point in the same connexion is, that flowers nearly allied often differ very much in some one particular. Thus Sir J. Lubbock tells us, ${ }^{3}$ with regard to two equally common species of Mallow : "In Malva sylvestris, where the branches of the stigma are so arranged that the plant cannot fertilize itself, the

\section{Taraxacum officinale.}

2 "Glabrous, or cottony at the crown and involucre. Root long, stout, black. Leaves oblong obovate or spathulate, lobes usually toothed. Scapes one or more, ascending or erect. Head $\frac{1}{3}-2$ in. broad, bud erect ; involucre campanulate, outer bracts more or less recurved, inner erect. Corollas bright yellow, outer often brown on the back. Fruit brown, with a beak of equal length" (Sir J. Hooker, Student's Flora. ed. 3, p. 240).

${ }^{8}$ P. 41 . 
petals are large and conspicuous, so that the plant is visited by numerous insects; while in Malva rotundifolia the flowers of which are comparatively small and rarely visited by insects, the branches of the stigma are elongated and twine themselves among the stamens, so that the flower can hardly fail to fertilize itself."

Here, then, are two species which have both contrived to develop into mallowhood, which are constructed so exactly alike that in any systematic catalogue they must stand side by side, and yet which differ in the one particular which we are told rules all development. Insects have worked for generations at the one, and have done nothing for the other, and yet they have both arrived at the same point, and both agree exactly in their complex generic peculiarities. ${ }^{1}$ And here again it is not in one or two individuals that this strange diversity and stranger agreement are found. These two mallows are each distributed over Europe, North Africa, Siberia, and Western Asia, even as far as India. Such development in all the varying circumstances of this area would certainly seem to be beset by unsurmountable difficulties.

It seems, then, that our knowledge of the mystery of flower life is still far from sufficient to justify us in undertaking to explain the secrets of their inner history, and that the explanation which we have seen offered is insufficient. As already said, nothing is so dangerous as to champion theories when they are but theories, and to allow our natural sympathy for the offspring of our own brain to mislead us as to facts. That our knowledge on the subject of flowers is insufficient, Sir John Lubbock appears in one chapter frankly to avow. $\mathrm{He}$ says :

${ }^{1}$ How complex these are may be judged from Sir J. Hooker's description of the genus : "Leaves angled, lobed or cut. Flowers axillary. Calyx 5-fid, 3-bracteolate. Staminal column long, filaments distinct at its top only. Ovary many-celled; styles stigmatose on the inner surface. Fruit a whorl of indehiscent $\mathbf{I}$-celled carpels separating from a short conical axis. Seed ascending, albumen scantly mucilaginous" (Student's Flora, p. 75). 
"Our knowledge of the subject is as yet in its infancy. ... Most elementary treatises unfortunately, though perhaps unavoidably, give the impression that our knowledge is far more complete and exact than really is the case. . . . Few, I believe, of those who are not specially devoted to zoology and botany have any idea how much still remains to be ascertained with reference to even the commonest and most abundant species." 1

But although incomplete and insufficient for full explanation, the knowledge gained through observation may well suffice to point in one direction, and I shall be much surprised if, on calm consideration, that direction is found to be the blind and fortuitous work of unreasoning agents. As Sir John, in yet another passage, parenthetically remarks, ${ }^{2}$ "It is difficult to account for the relations which exist between flowers and insects, by the hypothesis of a mere blind instinct on the part of the latter."

This brings us back to the consideration with which I started. I do not believe that insects, as a matter of fact, have done all for flowers which is claimed for them; but were it proved to the full that no colour exists in our fields and gardens which has not been developed by their agency, the ultimate solution of the question which heads this paper would be as far from us as ever. To prove all that I have supposed would be to prove no more than that our bees and butterflies are the paintbrushes of nature: we should still have to ask who is her artist? It is needful to dwell emphatically on this point, for when once we have traced effects to a mechanical cause, there are many who bid us rest satisfied as with a final explanation. But such is not the verdict of true science. "We now believe," says Professor Weismann, "that organic nature must be conceived as mechanical. But does it thereby follow that we must totally deny a First Universal Cause? Certainly not; it would be a great delusion if any one

$$
\text { : } 178 .
$$


were to believe that he has arrived at a comprehension of the universe by tracing the phenomena of nature to mechanical principles. He would thereby forget that the assumption of eternal matter, with its eternal laws, by no means satisfies our intellectual need for causality. We require before everything an explanation of the fact that relationships everywhere exist between the parts of the universe." 1 And the same author, than whom it would be impossible to find a higher authority, quotes with approbation the words of Von Baer: "The laws of nature are the permanent expressions of the Will of the Creative Principle."

Briefly to recapitulate. It is maintained, on the one hand, that all the beauty of flowers can be explained on Darwinian principles, as being of advantage to them in the struggle for existence by attracting the visits of honey-seeking insects, which assist the process of fertilization. It appears, on the other hand, however, that there are many difficulties in the way of such a theory, to be found by ordinary observation in the fields around us. The problem of beauty of form remains untouched by such an explanation. There are conspicuous and highlycoloured flowers which contain no honey, and others which produce no seed ; while some of the least noticeable of blossoms are richest in honey and the greatest favourites of bees. Some of the most successful tribes of plants do without insect agency, and prosper better than those which employ it most, and some which largely employ it, never being fertilized, obtain no benefit in return. Plants of the same genus may differ absolutely in their attitude as to insects, and yet their development be so little affected that they bear their affinity to one another stamped upon every feature, and no diversity of insect workers can alter any one minutest character in individuals of one species.

1 Studies in the Theories of Descent. English translation, with Preface by Darwin. London, 1882, vol. ii., "On the Mechanical Conception of Nature," p. 716. 


\section{4 \\ Who painted the Flowers?}

In view of all this, is it scientific to flatter ourselves that we have probed the whole mystery to the bottom, and to lay down that to insects alone do we owe the beauty of our gardens and the sweetness of our fields?

Felix qui potuit rerum cognoscere causas, says the Roman poet, but it is no part of true happiness, nor of true science, to boast of knowledge which we do not possess and to become so enamoured of theories as to lose the power of rightly estimating facts. 


\section{Fome Vulapside $\mathbb{P r o b l e m s}$}

IT is generally assumed nowadays, that science has spoken the last word on the subject of life and its developments. $\mathrm{He}$ that would not be considered a mere Philistine must profess to hold the great creed of Evolution, and must do so, not because he himself understands the proofs on which it is supposed to rest, but because it has been worked out by experts in laboratories and dissecting-rooms, because it comes to him on the authority of men better than himself, men who can talk familiarly of cellular tissues and protoplasm, of ganglia and nerve centres, and the supra-condyloidforamen.

The creed which comes to us thus authenticated is this. That in the struggle for life, ceaselessly going on upon the earth, those qualities or habits or attributes are perpetuated and developed which enable their possessors to survive, while others perish, so that not only do we see in the creatures now existing the "winners in life's race," but we also learn from examination of their constitutions, manners, customs, and tastes, what it was that enabled them to win. Here, we are told, is the explanation of all we see. The Squirrels in our oak woods have survived to be there, because they could crack nuts impervious to their rivals. The acorns are there, and therefore the Oak-trees too, because these nuts baffled enemies to which other nuts yielded. If Crows are black and Flamingoes are scarlet, it is only because these uniforms enabled their several ancestors to march respectively more triumphantly to victory. Nightingales sing because the practice has proved useful to Nightingales, and Strawberries develop III. 
their misnamed fruit because in commercial phrase the article has been a paying one. Nay, more than this; the ideas which we are apt to consider the most deeply rooted in our own nature are but evidences of what has helped to pull our own forefathers through their primeval difficulties. What we call the true, the good, or the beautiful, is but what has proved advantageous in the long run towards winning the aforesaid race. If men agree to stamp dishonesty as bad, it is because in a very strict sense honesty has been the best policy, and if we instinctively admire the hue of a rose, a glacier, or a rainbow, it is because a keen eye for such colours was once upon a time a useful thing to have, when fruits so tinted formed the food of our distant kindred.

The last-mentioned articles of the evolutionary creed are held, it is true, or at least are preached, only by the more extreme of its disciples: still preached they are, and they should not therefore be omitted from a review of its features. At present, however, my business is not with them. The relation between evolution and the soul of man is a subject too vast to be treated conjointly with any other, and I am just now concerned with the more primary and simpler question as to how far the doctrine so incessantly and so confidently propounded is to be admitted by us as proved in regard of the external world of which our senses tell us.

In approaching this inquiry, there are two points which I hold to be clear, though one of them at least may not generally be much regarded. Firstly, the evolutionary doctrine is after all but a theory-and like other theories should be judged by its accordance or non-accordance with facts. And it must fit all facts. It is not sufficient that of some here and some there it should seem to afford a plausible explanation; nor on the strength of its so sufficing may we assume that in other cases where no such explanation is forthcoming it nevertheless exists. We are dealing with that which claims to be the key to unlock all the riddles of nature, and every riddle which it can make no attempt to unlock 
is a stronger argument against it, than those which it seems to fit are for it, since there may obviously be more explanations that one of the same phenomenon. At least until an overwhelming majority of observed facts declares unmistakably for the theory it is hardly scientific to adopt it as a basis of argument and to call it even "a working theory."

Secondly, the facts which demand consideration are not those only which present themselves to the initiated few. It is not needful that a man should know how to work with a microscope or a scalpel in order to be capable of doing at least something towards the formation of his own opinions. As I have said, all the facts of nature have a bearing on the question under consideration, and every wood and heath and hedgerow presents facts enough and to spare for the study of any one who will use instruments no more recondite than his own eyes and brains.

Any one who will do so will not improbably come speedily to the conclusion that things are not, to say the least of it, so plain and obvious as the books and lectures of his would-be teachers might incline him to suppose. No doubt with some of the facts of nature the evolutionary hypothesis does seem to square well enough, as a plausible or possible explanation. But amidst the endless multitude of phenomena which meet us at every turn, what proportion suggest such an explanation or even seem to admit it? Is it not possible that those who are interested in the theory set too much store by the instances which favour their pet doctrine, and too little by all besides? Is it not at least the more scientific course to go to nature oneself and ask oneself such questions in her presence?

We certainly shall not have far to go for cases in which the accepted scientific account is not too obvious. Is it, for example, quite evident that Moths have in the long run benefited by their inveterate habit of flying into candles? or that it has been a good thing for Linnets and Salmon to be so fascinated by a light as to make 
possible the operations of bat-fowling and "burning the water"? Might not May-flies and Spinners have discovered a method of depositing their eggs in water without the preliminary evolutions on its surface which are so convenient for the Trout? Have Wheatears been proved to be any the better for their propensity to drop into the first hollow they come across, a propensity on which the shepherds of the southern downs trade so largely? Have Wild Ducks any substantial advantage to show for that readiness of theirs to follow a red dog which leads them in hundreds into the decoys of the fens? or have Sheep improved their position in the world by the practice of huddling together at the sight of a dog and impotently stamping? When a Blackbird flies screaming out of a bush, does he do himself any particular good to compensate the advertisement of himself which he gives to those who do not wish him well? Though it may probably be a valuable assistance to the hen Nightingale that her mate should sing to her when sitting on her eggs in spring, does the same explanation equally apply to the autumn song of the Robin? Is it so very certain that the Strawberry has been signally aided in the struggle for life by its edible fruit, seeing that its cousins the Potentillas have thriven even better without one? How has the Little Celandine found a return for the cost lavished on its blossom, which scarcely ever performs the proper work of a blossom by producing seeds.

These are a few specimens, taken at random, from among the multitude which thrust themselves upon the notice of any one who gives any attention to the facts of nature. And any explanation of the methods of nature which claims to be accepted as final must easily fit itself to such. All I am at present concerned to argue is that as yet we are not in possession of any account so obviously satisfactory as to justify us in dogmatizing or in pluming ourselves on having attained the felicity promised to him gui potuit rerum cognoscere causas. 
And even in those instances which the champions of the evolutionary dogma cite on its behalf, may it not sometimes be that the explanations offered are more apparent than real? To take, for example, the case of the acorns. They, we are told, have survived because they by their increasing hardness beat off various tribes of enemies that had lived by opening them; something in the same fashion that ironclad ships have lived down the ordnance of the days of Nelson. But, firstly, would not a small development of poison in their kernel, of strychnine or prussic acid, have proved more easily effectual than a great deal of external armour? And might we not therefore most naturally have expected all threatened fruits of this sort to have by this time become deadly? And, secondly, is it quite certain that acorns have really benefited by having killed off all other enemies but Squirrels, if Squirrels remain? It is not the number of species, but of individuals that is important, and there may easily be as many individual Squirrels in the woods now as there were individual acorn-eating animals fifty centuries ago, though recruited from a dozen different tribes.

It is, I hold, a wholesome and useful practice to check the dicta of books in such fashion as this by observation of facts and by independent reasoning upon them. It is far more scientific thus to use one's own means of knowledge, however limited, than to resign oneself helplessly into the hands of a teacher, however eminent. And assuredly, as I have said, though limited the means of knowledge presented to all who will use them are ample enough, and increase with the using. It is my present object to point out a few common and easily verified examples.

In the first place, let us take the case of our common twining plants. As is well known of those plants which avail themselves of strength other than their own to raise them upwards, some, as the Vine, the Pea, and the Clematis, make use of tendrils wherewith to clutch the support of which they take 
advantage. Others, like the Ivy, develop for the same purpose what are called aerial roots. Others again, as the Convolvulus, the Honeysuckle, and the Hop, being furnished with instruments of neither sort, mount by twining, like snakes, with their whole growth round and round their prop. It is quite conceivable that this habit has been a benefit to them, or any habit which helps them upwards towards the light and air, quo cuncta gignentium natura fert. But is it equally comprehensible that it should make any serious difference to a plant whether it turns to the right or to the left? ${ }^{1}$ Yet each species adopts one course or the other, and keeps to it pertinaciously. The Convolvulus and the Scarlet Runner, for example, always go to the right: the Honeysuckle, the Hop, the Black Bryony, the Climbing Persicaria,

1 These terms are, if unexplained, in danger of being highly ambiguous. Indeed, it is said to be a sure method of starting a conversation in any company to turn some object round and round one way, and ask whether it is turning to the right or to the left. Should this by some chance fail to produce the desired effect, all present agreeing, it is only necessary to inquire further why such motion should be so described, and discord must inevitably follow. It is indeed curious to note how hard it is to describe an absolute difference in relative terms such as these, and how utterly different modes of reasoning will commend themselves to different minds. Take, for example, the case of a plant twining like the thread of an ordinary corkscrew. Should it be said to twine to the right or to the left? To the right, says one, because its course is the same as that of a boy swarming up a pole, and always following his right hand. To the left, says another, for it is like a spiral staircase, in mounting which one must turn on his left. To the right, says a third, because looking at it from without the part nearest the eye goes upward to the right. To the left, argues a fourth, for fancy yourself to be the prop in the middle, and the plant will cross your breast towards the left. These various explanations are in fact found in print. As it seems impossible to settle such a question on its merits, it will be convenient to define the sense in which the terms are used here. If a man clasping a tree-trunk preparatory to climbing were suddenly, after the manner of Daphne, to be changed to a plant, his arms becoming twining shoots, his right arm would be said to twine to the right and his left to the left. 
always to the left. It is useless to attempt to make them reverse their practice. They will untwine and fall from their support rather than do so. It is not, I repeat, a little difficult to understand what particular advantage they have gained by such pertinacity? It will perhaps be said that the first plant of each species which developed the twining faculty adopted that mode of twining which has been perpetuated in its descendants. But such an explanation does but land us in a region of mystery lower still than that from which it seeks to extricate us. It would mean that all individual Convolvulus plants, for instance, are descended from one original progenitor. Yet this is precisely what evolutionists, when arguing against the fixity of species, assume to be impossible. The idea which they are never weary of inculcating is that like circumstances have in countless different instances produced like results, different individuals of one form being forced by their surroundings into another. But can the circumstances have been so absolutely identical as this? And it must not be forgotten, keeping still to the instance I have taken, that there are a multitude of species of Convolvulus differing widely in many respects, but agreeing in their mode of turning. Does the evolutionary hypothesis afford any very satisfactory mode of accounting for such agreement coupled with such difference.

This topic suggests another remark in confirmation of my contention that there is a large field for the most ordinary observer to work. in. One of the few books in which I have found any notice of this singular feature in the habits of such plants, after enumerating examples of those which adopt a determined course, goes on to say, that others vary their practice, some individuals of the species twining one way and some the other, and as an instance of this cites the Bittersweet, or Woody Nightshade (Solanum Dulcamara). Now, if true, this is singular, so singular as to deserve verification. Luckily the Bittersweet 


\section{$5^{2}$ \\ Some Wayside Problems}

is a common enough plant, and a very short hunt down a hedgerow any time in summer will suffice for the discovery of its purple and orange blossoms, in form so like the flowers of the potato as at once to mark their relationship. In autumn its brilliant red berries will be still more conspicuous. A very brief examination will show that the plant cannot properly be said to twine at all, not at least in the same sense as those already named. It straggles and clambers up through a bush, elbowing itself up chiefly by means of its leaves, which do the work of exceedingly rude tendrils, the upper leaves being furnished with ears at the base to facilitate the process. But in particular it will be observed that though the stem, more from force of circumstances than from any natural instinct of its own, does occasionally make a coil round some object, it has no sort of attachment to one or the other direction. It is not that some plants go one way and some the other, the same shoot of the same plant will occasionally do both. This fact, though of no particular value for the general purpose of my remarks, is yet valuable as showing the need there is for individual observation even of those facts which would seem to be the best attested. ${ }^{1}$

Another matter which suggests difficulties of a similar kind is the practice of most flowers to close at night. It is said that to be open during the day is a clear advantage, because then insects are astir which help to fertilize them, and so to propagate their race; and that to be shut at night is equally advantageous as preventing rain or dew from spoiling the delicate machinery of stamens and pistil. So far so good. But what of plants which close just at the

I With regard to the plants which truly twine it has been suggested that their course may have some relation to the motion of the sun. It would be interesting to know how they behave in the southern hemisphere where, according to this idea, their motions should be reversed. 
time when, according to this theory, it would be best to open? A notable instance of this is the Goat's Beard (Tragopogon pratensis), known from its practice in this respect as "Jack-go-to-bed-at-noon." This flower, one of the multitudinous tribe which many compendiously set down as "dandelions," is wide open in the early morning. By the time that the sun is half way to the meridian it has begun to put up its shutters, as if to warn intending visitors that its business hours are over, and by twelve o'clock it is fast shut, just when the insect world is appearing in fullest force. Yet notwithstanding its go-to-bed habits the somnolent plant seems to get on in the world quite as well as most of its more wakeful and harder working neighbours. It ripens its fruit in abundance, and is very tolerably plentiful through the length and breadth of the land. Paying no attention to the law which we are told to regard as governing plant life, and exhibiting no sign of suffering for its negligence, it certainly suggests a query as to whether the said law be absolutely established.

If the Goat's Beard contradicts the law in one way, the Globe Flower (Trollius europaus), also a fairly common species, does so in another. The former shuts itself up at noonday, the latter never opens at all. Instead of regarding insects as the most precious of all visitors, to be allured at any price, that in their comings and goings they may carry pollen to and fro and secure cross-fertilization, the globe flower constructs with its petals a covering, something after the manner of a Roman testudo, which so effectually shuts in its stamens and pistils as to make it morally impossible for anything but selffertilization to take place. So grevious an offender against vegetable economics ought assuredly to come to speedy ruin, yet in its favourite soils it flourishes exceedingly, and up the moist valley of many a Highland stream its flowers are thick as are Buttercups elsewhere. 
So much for instances wherein the laws which we are told govern development seem to be ignored, or even contradicted. There are other cases in which the processes of change from one form to another exhibit themselves as considerably different from what we are told to expect. In theory the processes should be exceedingly slow. An animal, or plant, so to say, gropes its way in the dark towards a better form. A flower, for example, produces seeds, and the seedlings which grow therefrom are none of them the exact facsimile of the parent, nor of one another, but differ, infinitesimally it may be, in various particulars. Those whose differences are in a profitable direction are the most likely to survive, and from them will spring others in which the useful features are developed still further, and so on in ever succeeding generations. It is the external circumstances which rule the changes of growth, not any motive force internal to the plant itself. Yet here again it is not hard to find tongues in trees which seem to tell a very different story.

There is a plant exceedingly abundant in spring beside water or in the damp places of woods, known in botanical English as the Water Avens (Geum rivale). Bearing a very dusky and inconspicuous flower, it is likely to escape common notice, though mediæval architects were so smitten with the form of its leaves as to model on them much of their foliage. It is a little singular that a plant thus selected for the purposes of ornament should seem to have a decided taste for self-beautification. Its common form, as has been said, is not striking to the common eye. But among plants of the ordinary type there are sure to be found some which altogether change their habit of growth, and do so not in the tentative and gradual fashion which evolutionists describe, but with surprising thoroughness.

The two plants bear commonly drooping flowers of dusky red or purple hue, almost brown. On the 
stem are three or four leaves of unequal size, and three other leaves springing from the root down below. These various appendages are the raw material to which the plant is confined for its purposes of adornment, and it uses them thus. In place of two flowers on each stalk, the exceptional specimens develop one only, of far greater size. This one flower is made double. The doubling of flowers, as is well known, is effected by changing stamens into petals, and a flower that does this dooms itself to sterility. The Avens, however, seems resolved that if it makes this sacrifice it will have a quid pro quo in the way of beauty, and it accordingly colours its now abundant petals far more brilliantly than seems to be their nature, so brilliantly that they are often as ruddy as a Rose. Not content with this, it draws its leaves together, bringing up not only those on the stalk, but some from the root, to make up the orthodox number of five, ${ }^{1}$ and bringing them approximately to the same size and form, arranges them something in the fashion of an Elizabethan ruff round its altered flower. The effect is most artistic, and few who are not botanists would imagine that the quaint prim little plant with delicately-tinted blossom could be of the same species as the lax and straggling growths, with dusky nodding flowers, which surround it. Here then is an instance in which development takes place in a given direction at a bound, and apparently on a plan. Moreover, the individuals which exhibit such development being sterile, can do nothing towards handing on the tendency. Yet every season fresh examples of it occur. In some cases the development goes still further, the pistil, whose proper function is to be a seed vessel, changing into a stalk and growing up through the transformed flower, with leaves upon it, and another attempt at a blossom up aloft.

${ }^{1}$ Such a plant as the Geum has 5 petals and 5 sepals. As a general law, exogenous plants adopt the numbers 5 or 4 for their various parts, and endogenous plants the number 3 . 
Another common plant, the Lady's Smock (Cardamine pratensis), frequently exhibits the same sort of change.

A less frequent instance of a striking change of habit suddenly occurring is afforded by the little scentless Dog-Violet (Viola sylvatica), which is so common everywhere in April and May. To look at the lowly prostrate plant, whose family has been taken as the emblem of humility, nothing could seem further removed from the rampant climbers with which I began, plants that employ every parasitical device to thrust themselves into prominence. Yet I have known the Violet do just the same. It was on the borders of the little Welsh river Aled, late in October, many years ago, that an unusual-looking blue flower half way up a hedge caught my attention. Examination showed this to belong to a long straggling stem, two and a half feet long, but an indubitable Violet. Instead of staying its growing operations at the usual season, this specimen had, to gain its private ends, continued to develop its main shoot, from which sprang off laterally alternate leaves, with flowers in their axils, and it had multiplied these leaves to the number of sixteen. Of flowers there had presumably been an equal number. That which caught my eye was the only one still blooming, but below it were several seed-pods. Altogether, except for the circumstance that it was a Violet, nothing could less have resembled that plant.

It would be easy to extend the list of such phenomena, but the catalogue might not improbably grow wearisome, and those which I have mentioned are sufficient for my object. It is quite clear that there is abundant matter for observation within reach of all, and it seems to me no less so, that we shall find reiterated to us in many ways the lesson of our own ignorance. The making of theories is a fascinating pursuit, and nothing is more attractive than to find facts tally with a theory we have made. There is therefore no little danger lest con- 
venient facts should be taken and inconvenient facts left, and that hypotheses should therefore be held as proved which we have taken no real step towards demonstrating, and that whilst we are priding ourselves on having sounded the bottom of all knowledge, we should in reality be all the time, like Newton, children on the sea-shore picking up a shell or a pebble here and there, while the limitless ocean with all its treasures rolls before us unexplored.

It may be said that the facts I have instanced and others like them must admit of some explanation, and that the arguments here used would, in some cases at least, appear to suggest that no explanation is possible. What, for instance, about the self-immolation of moths and other insects when they see a light? But such examples tell only against any blind operation of merely mechanical laws. Once admit a design in the processes of nature, and there is no phenomenon but may well be part of that design. Not only the propagation of a species, but its confinement within suitable limits, or even its extinction in favour of other forms, may be in the plan of the Designer. "Foumarts," 1 said a veteran north-country gamekeeper, "are the clumsiest things about a trap. They'll go into anything, a box or a cage, it doesn't matter; and they'll walk on to a trap that's hardly tried to be hidden: they seem never to look under their feet." Clearly this gives them no great assistance towards multiplication-but their multiplication may possibly not be intended.

So too their cousins the weasels are cursed with a curiosity which goes far to neutralize the benefit of the proverbial fact that they are not to be caught asleep. If one escapes the gunner by reaching the security of a hole, his enemy has only to wait patiently in sight of it, and he will not have to wait long. Infallibly the creature will pop out its head again to have a look at the stranger, and in so doing will give the stranger a sight in return.

${ }^{1}$ Polecats. 
The primary fact whereof we have to take account in our investigation of the world of life is that it is a machine which works. Its actual efficiency is far more manifest to us than are any of the hypothetical explanations which we hear, as to how that efficiency is secured. Looking at the universe in its separate parts only, and conceiving of the various tribes which make up the organic kingdom, as separate and independent one of another, fighting each for itself alone, we obtain no key to the mystery that the outcome of this chaotic antagonism, should be that orderly Cosmos which it is the pride of science to contemplate. Looked at, for instance, from the point of view of the vegetables, what advantage had any plant to gain by producing a digestible seed? All that comes of such a quality is to secure, that, the seed being consumed by bird or beast, the propagation of the plant, so far as that seed is concerned, should come to nought. Yet without such seeds-our wheat, barley, oats, rye, rice, peas, beans, and nuts, - what would become of us men, who are yearly within measurable distance of starvation if the harvests of the world fall short of their due amount? In like manner we may ask what advantage has accrued to our cattle and sheep from their latent capacity of producing beef and mutton,-to the horse from his powers of traction,- - to the dog from his aptitude to be trained to herd a flock, or point at a covey, or turn a spit. Yet all these various qualities-and a hundred thousand others-fit in with the complex requirements of the world as we know it, and make its operation possible. Not the independence of each factor, but their interdependence is the great fact whereof evidence stares us in the face at every turn, a fact demanding an explanation, and explained, at least more simply than in any other manner, by supposing it to be the result of design.

But here we touch the crucial point of the whole matter. This admission of design is what the most vehement preachers of evolution are chiefly anxious to 
avoid. Indeed, they make little secret of the fact that their zeal on behalf of the forces of nature is in large measure owing to their belief that the machinery of those forces is sufficient to account for the construction of the universe without an Architect. The blind action of natural laws, the struggle for existence, the survival of the fittest, are sufficient to account for everything; that which it requires mind to explain, required nevertheless no mind to form. ${ }^{1}$ It is against this doctrine that the foregoing arguments, and other such, have weight, and he who will in any degree attempt to read nature for himself, will doubtless in no long time come to two conclusions: the first that in every direction mystery bounds our knowledge; the second that where our minds do contrive to penetrate, there has been Mind before them, and that to read the purposes of that mind must be the highest ambition of ours. And this it is that constitutes the true charm of scientific investigation. An historian once contemptuously dismissed the chronicles of the Heptarchy as no more worthy of attention than the battles of kites and crows. Natural history would be something still worse if it dealt but with the aimless and random workings of blind forces. How different the view of such a discoverer as Kepler, exclaiming: "O God! I think Thy thoughts after Thee!" This frame of mind is not devout only, but alone rational and scientific. Dieu explique le monde, et le monde le prouve. ${ }^{2}$

In attempting to explain the origin of all things by mechanical forces alone we are attempting a task which is, and must ever remain, impossible. Granting all that our scientists assert, the question of the ultimate cause remains still unanswered. "I believe," says Professor Weismann, ${ }^{3}$ " that the theory of selection by no means leads - as is always assumed - to the denial of a teleo-

1 "Quoi! le monde formé prouverait moins une intelligence que le monde expliqué !" (Diderot).

${ }^{2}$ Rivarol.

3 Studies in the Theory of Descent. English translation, p. 716. 
logical Universal Cause and to materialism, and I hope thereby to have cleared the way for this doctrine, the importance of which it is scarcely possible to overestimate. Many, and not the most ill-formed, do not get so far as to make an unbiassed examination into the facts, because they are at the outset alarmed by the, to them, inevitable consequences of the materialistic conception of the universe. Mechanism and teleology do not exclude one another, they are rather in mutual agreement. Without teleology there would be no mechanism, but only a confusion of crude forces; and without mechanism there would be no teleology, for how could the latter otherwise effect its purpose.

It is well to insist on this truth, obvious though it be. Scientists too often are so overcome by the wonders they meet in nature as to make the mechanism itself the object of their homage. But this, under the style and title of science, is thinly disguised Fetishism. The idea of mechanism is altogether unmeaning, without that of the end which it subserves, and of the Designer who contrived it, and it is to Him that the universe bears witness.

These are Thy glorious works, Parent of good, Almighty; Thine this universal frame

Thus wondrous fair. Thyself how wondrous then! 


\section{"Jjebold the JBit's of the Flir"}

THE Oxford tutor ${ }^{1}$ who has made the public his debtor by his Year with the Birds, confesses to an experience at which some at least of his readers are likely to stand aghast. He began life as an angler, and not only has forsaken his art, but considers that he, as well as the Trout, is a gainer by the renunciation. That an ignorant Philistine should speak disrespectfully of the gentle craft, is only what every fisherman pityingly expects; but that any of the initiated should cut himself adrift from the brotherhood of anglers, is what probably none of that brotherhood ever deemed conceivable. Do not fishermen boast that, quite apart from the question of mere success in killing, their pursuit is essentially that of the contemplative man, the most idyllic of all out-door pastimes? that it not only leads its votaries into the most beautiful corners of the land, but likewise puts them in a frame of mind to appreciate their beauties? that, as an American writer has it, no one is in a condition to enjoy scenery to the full, unless he have a fly-rod in his hand and a fly-book in his pocket?

The instance is therefore phenomenal enough to suggest inquiry as to what charm it is, that has availed to break a spell usually so potent, and what master so seductive as to allure a disciple away from the school of Izaak Walton, - and the answer which this query evokes presents us with an interesting specimen of those re-

1 The Rev. W. Warde Fowler.

IV. 
venges which it is the habit of Time to bring. It is the man of birds, routed in the dialogue with which the Compleat Angler opens, who has got the better of the fisherman, though the man of birds is in this case Auspex the Ornithologist, not Auceps the Fowler. In other words, the fishing-rod has been resigned in favour of a binocular, and an object has been found for country walks, in the observation of the manners and customs of Wag-tails and Willow-wrens, instead of attempts to allure the wary and suspicious Trout.

Fishermen, as I have said, are members of a craft which is indeed a mystery to outsiders, the charm of which can never be understood by any with whom the sacred fire is not inborn. But it is probable that to a still larger multitude this substitute for angling will seem even less delectable. The man who goes roaming about the country, poring with his glasses into tree-tops and hedge-rows, must look to having his pursuits as irreverently described as were those of his brethren the geologists, by worthy Meg Dods, "And some ran up hill and down dale, knapping the stones to pieces with hammers, like so many stonebreakers run mad; they say it's to see how the world was made."

This is inevitable; but it is to be doubted whether those who can speak from their own experience will join in the outcry. It is the peculiar charm of field observation that it puts a point on that which otherwise is pointless, and by making us note variety, creates interest. Botany accentuates a multitude of shades in the seasons of the year, not only the Primrose, the Violet, the Rose, and the Heather, but every obscure waif and stray of the vegetable kingdom making its mark on the calendar, each as it comes hanging out its own private signal, and claiming welcome as an old friend. Ornithology deals with places rather than with times. It does not, to be sure, omit the latter; the autumnal appearance of the Fieldfare and the Woodcock is an event to it as in- 
teresting as the appearance in spring of the Cuckoo or the Swallow ; but it is by quartering a district out into habitats for different species, that it adds chiefly to the interest of a country walk. There is the upland moor, where may be sought the Snow-bunting in winter, and the Ring-ousel in summer; the fir-woods, which are sure to exhibit a nomadic company of Gold-crests, Red-polls, and Cole-tits, perhaps a family caravan of Long-tailed Tits; the swampy bits down below, which the Sedgewarbler enlivens with his petulant chatter and comical mimicries; the sheltered spot where far into the winter the Grey Wagtail sera moratur. Sometimes there is one spot, and one only, in a whole country side, where a Wood-wren or a Chiff-chaff may be heard, or a Dabchick seen.

Nor will the observer be long at work before he discovers, as in other branches of natural investigation, what marvels lie hid behind the veil which hitherto he has been contented not to lift. Before we begin to train our eyes by using them, we are vaguely conscious that there are birds of various species in our woodlands and our fields, and that of these species some come and go at their appointed times. It turns out in fact that, except during the comparatively brief period when they are anchored to one spot by the all-absorbing solicitude of nesting, the tide of bird-life is in a continual ebb and flow. In winter, with every spell of frost, numbers move away seawards, and with every promise of open weather return inland. In the later surnmer, migration of individuals, and even of larger bodies, sets in long before the season when a whole species disappears. Many birds, which we suppose to be always with us, are reported by observers at sea or along the coast as furnishing their quota to the army of migrants-Jackdaws for instance, and Rooks, and even the familiar Robin. Our home-bred Larks, we are told, dwell in their native fallows only until others of foreign origin come in and dispossess them, and then move off to do the same, presumably, by others. Nor are their routes of travel 
less remarkable than their seasons. From certain definite points of the coast do they start their long flight across the sea, and not from others; and to the same do they return. An observer, for example, on the Norfolk coast may catch scarce a glimpse of the spring immigrants, while at the same time sailors and light-ship men, a few miles off, report dense converging streams pouring towards the estuaries of the Trent and the Humber.

Migration is the broadest and most striking feature of bird-life, but it is one feature only out of many which will reveal themselves to eyes that care to look. The manners and customs, the associations and antipathies, of various species are each a subject of study and of marvel ;

\section{The modes of life}

Native to each, and what, among themselves

Their feuds, affections, and confederacies. ${ }^{1}$

Whence for example, to take but a few obvious examples, do the Crow tribe get their proclivity for running away with shining objects? Do they indulge the practice in the wild state? or is it a taste developed only by domestication? The Oxeye-tit too, when at large, is not known to batter out other birds' brains and devour them, but this he will certainly do if confined in an aviary. Why do small birds mob the Cuckoo? Is it because they recognize in him a disturber of their homes? And if they so recognize the parent bird, how are they so inconceivably obtuse as not to detect the nature of his enormous brute of a son, hatched in their own nests, which they will sometimes go on feeding even when he has grown so far beyond themselves that they must perch on his back to reach his mouth? Why do Titlarks assault Missel Thrushes? and why do the latter, large and not sweet-tempered birds, submit to be so 
bullied? Why does the cock Wren employ his spare time during the breeding season in making fictitious nests, wherein no egg is ever laid? What governs birds in their choice of building materials? A Chaffinch for instance will as a general rule pick his moss and feathers, and make of them a nest most artistically toned to its surroundings. But only this last spring, ${ }^{1}$ one such bird, at least, gathered from a decayed stump a mass of white touch-wood, and built it up plain for all passers-by to see, conspicuous against the black bole of a fir-tree. Was this departure from usage induced by the fact that the builder's lot was cast where no nest, however secreted, could remain undiscovered, and where every nest, however unconcealed, was safe?

It seems not wonderful, therefore, that those, in whom a love of nature is inborn, should find that animals can afford them entertainment otherwise than as objects of slaughter; and that an addition to one's stock of facts about them should be held as great a prize as a full creel or heavy game-bag.

It was in observations such as these that Gilbert White and many a follower since his time have spent blameless days, finding, no less than Isaak Walton himself, the longest summer day too short for all the uses they would fain have put it to. Fortunatos nimium! Their days and their ways are not ours, and the pursuits they loved cannot be for us what it was for them. A new presence-that of science-has made itself conspicuous in this as in other fields, and not for the first time the fruit of the tree of knowledge has served to bring to an end the placid peace that reigned, before it was tasted, in the paradise of Nature. Gilbert White was satisfied to note the birds without any questionings except those which his eyes could answer, to discriminate a new species of Pettychaps, and speculate on the hibernation of Swallows. But now the schoolmaster is abroad and has turned 
every object into a text for deep philosophisings, and do what we will we cannot bear ourselves as if we had not his teachings in our ears. Whether we agree with those teachings or disagree, we cannot but recur to them in our observations, nor avoid asking ourselves how they square with the facts falling under our eyes. Such collation of facts and theories is just what modern science impresses on us as a duty; but, as I have had to confess before, the examination of the simple phenomena which it is in my power to observe, does not serve to impress on my mind the truth of the conclusions most in vogue; but suggests doubts and disquietudes as to their soundness, almost as much as the arbitrary assumptions and dogmatic declamations of the most positive and intolerant of their upholders.

The cardinal doctrine, as everybody knows, of the new evolutionary creed is that there are no such things in the organic world as species properly so called. That is to say, the various types of animals and plants, which we see around us, are but various modifications of one original, the descendants from which have variously developed into dissimilarity according to the various circumstances in which they have had to struggle for existence. The host of birds, for example, is not a regular army, designedly portioned off into divisions and regiments, but a multitude fortuitously gathered round certain standards upon which in the march of life they have chanced to come; and those who have been led in the same direction, as if stained by the variation of the same soils, present to our eyes what we mistake for a uniform. They are all, to change the metaphor, carved out of the same block; but the carving has been done by blind forces, not by an artist's hand; it is the heat and the cold, the drought and the deluge, the accidents of climate, of companionship, or of soil, that have determined the forms and features and habits which present themselves to our observation. The Swallow would have been a Sparrow had his ancestors gone through experiences precisely similar to the other's, and 
on like conditions the Sparrow would have been a Sparrow-hawk.

With the general fact of development I am not concerned. The arguments in its favour are held by professed men of science to be too strong to gainsay, and indeed there seems no more difficulty in understanding how the divisions of animals and plants have been brought about by its agency than by any other. But if there has been development it has been upon a plan. It has been along lines laid down and intended, and in obedience to laws intelligently framed and artfully contrived. To say that Nature as we see it is organized by blind forces without a guiding hand, that the dice have fallen so regularly without being previously loaded, appears so incredible, as to make me wonder with Newton that any man "with a competent faculty of thinking" can fall into such an absurdity.

Sir John Herschel's observation is well known. "When we see a great number of things precisely alike, we do not believe this similarity to have originated except from a common principle independent of them : a line of spinning jennies or a regiment of soldiers, dressed exactly alike and going through precisely the same evolutions, gives us no idea of independent existence." 1 Now coming back to observations of the class whereof I have been speaking, is there anything more absolutely uniform, more obviously fashioned to a plan, than the various tribes of birds? What can be more absolutely identical than the deportment in similar circumstances of different individuals of one race? This is indeed a point which must soon impress an observer with a sense of weirdness and mystery. Looked at apart from his fellows, each individual would appear to be a perfectly spontaneous agent going through his tricks and devices at his own sweet will, with a thousand eccentricities of his own. But when we find the myriads of his fellows so faithful in their imitation that the books 
on our shelves can tell us beforehand what we shall see them do, down to the most minute particular, can the thought fail to arise, that for manœuvres so complicated there must be a word of command? Every Blackbird, for example, flies at our approach from his bush with precisely the same cackle; every Black-cap we try to watch will persistently manage to be behind a tuft of leaves; every Water-ousel settling on a stone sits there curtseying to things in general; a flock of Golden Plover will always turn with a simultaneous precision to which no battalion was ever drilled; Rooks, which appear to go about their affairs so deliberately, will always come back some time in autumn to sit lugubriously beside their nests; a flock of Bullfinches will always fly down a hedge in the same follow-my-leader fashion, making them impossible to mistake for any other species; a flock of Greenfinches can be no less easily distinguished, even at a distance, from other small birds, by their inveterate habit of wheeling about several times with such absolute precision before they alight as to appear and disappear to the eye according as the lighter portion of their plumage or the darker is turned towards the observer; while Siskins may be known by the occasional evolutionary excursions they simultaneously make to interrupt their feeding, and by their unselfish habit of inviting by general acclamation passers-by of their own kind to come and share their banquet; no Jackdaw has ever yet learnt the futility of trying to bring a stick crosswise through a crevice; the Tree-pipit's song is always delivered in precisely the same fashion, while with quivering wings and expanded tail he floats down in a semicircle to the spot he has but a moment left; and the Stone-chat will always be at the top of anything he settles on, be it a furze-bush or only a tussock of grass.

Examples of this sort might be multiplied ad infinitum and drawn from every one of the species we see around us. So absolute is the uniformity of their conduct, as to force upon us a conviction of their unity, as is shown 
by the way in which we are accustomed to speak of species and assign them a character as if to individuals. Thus an eminent naturalist ${ }^{1}$ writes of one of our commonest little birds, the Hedge-sparrow: "It is unobtrusive and harmless, of an amiable disposition, and deserves protection and support." The Long-tailed Tit is set down by another writer ${ }^{2}$ as a model of all the family virtues, though with just a tinge of eccentricity; while the common experience of mankind has prepared them to set down every Magpie they meet as a rogue, every Sparrow as a gamin, and every Robin as an old friend. The Wren will always persist in the seemingly purposeless labour of constructing several nests, before deciding which to use, and the astute egg-collector, when he sees little tufts of grass, as of the foundations of a nest, in the bushes, will conclude that there is probably a Blackcap's or a Garden-warbler's nest in the neighbourhood. The Starling, apparently to beguile the monotony of the long winter, will begin fussing about the place where he intends to build, weeks and weeks before he takes up the business in earnest; the Tomtit will inspect and survey all manner of eligible situations, and suddenly make up his mind to select what seems a most unsuitable one; while the Fly-catcher will have his site chosen and his house built within four days of his return from the south. Nothing, to our notions, is so fatal to hatching eggs as cold water, but every mother Grebe has a natural philosophy of her own, teaching her to bring damp weeds from the bottom of the water, and cover with them the eggs in her nest, when she wishes for a time to leave it. When walking across a moor, if we observe a bird flitting, in halffriendly, half-timid fashion, on our track, taking up a position somewhat in front of us, and as we approach advancing yet farther, again to await us, and so on perhaps for a mile or more from the spot we first observed him, we may be as certain as if we held him

1 Yarrell. $\quad{ }^{2}$ Johns. 


\section{0 "Behold the Birds of the Air"}

in our hand that he is a Wheatear. We know that a tame Swan will drive away Water-fowl, and that a wild Swan will not, while Coots will attract them to the water they inhabit. The Nut-hatch will run up and down trees; the Creeper upwards only; the Goatsucker will never perch across a branch but only sit along it, and so markedly distinguish himself from the Cuckoo and the Hawk for which on the wing he might easily be mistaken. Still as of yore the temple-haunting Martlet will prove himself the guest of summer, and to-day, as in the reign of King Duncan, we may observe that where these birds most heed and haunt the air is delicate; while the Ptarmigan, on the other hand, will not only frequent bleak mountain-tops, but shun their sunny side: and though the hens and young birds will come far into England in winter the male Snowbunting after he acquires mature plumage, scorning such effeminacy, will brave out the cold in more northern climes.

Not so mysterious as this similarity of character, but equally wonderful, is that of the outward form. This is a matter more easily demonstrated to the eye than the other, and yet it is doubtful whether many even amongst those that see birds every day, have ever noticed how marvellous it is. As an instance, I will take a bird which every one must know-the Chaffinch. Every cock Chaffinch has a black forehead, ${ }^{1}$ and a bluish-grey head and nape, with a narrow half-collar of oil-green, between this and the chestnut of his back: the quill feathers of his wing have each a narrow edging of greyishwhite; of the wing-coverts, some are always black, and some white, and one row is black at the base with a white tip to each feather: the inner primaries have each a white patch at the base of the outer web, while the

1 That is to say, in summer. In winter, the plumage of the head and upper part will with equal certainty be found obscured by the long brown margins of the feathers; the edging of the wing-tertials will be tinged with ochre; and the white of the wings with lighter yellow. 
pair of tail feathers next to the outer ones have each a narrow white outer margin and a triangular white patch on the inner web. Many other variations of colour would need to be described to give a complete picture, but these items will serve to show how intricate and seemingly arbitrary is the pattern according to which an array so multitudinous is yet uniformly clad. Surely never was a garb so complicated designed for a human battalion, not even that which Michael Angelo devised for the Pope's Swiss Guard; and never assuredly did human skill more accurately reproduce the simplest of designs. It makes the matter not less, but more astonishing, that the bird exhibits unmistakable tendencies to vary. A tinge of yellow is often, but not always, found on the greater wing-coverts, while instances of downright "sports," piebald and buff-coloured varieties, are not unfrequent. What is it that holds such tendencies in check, and instead of motley confusion, produces such practically persistent unity of type, that the next Chaffinch we chance to catch will be sure to agree with it down to the last particular?

How much labour it requires to keep any race up to a model of our own making, we know by experience; how much of the vis humana is required if we are not to see our carefully-produced varieties of animals or plants in pejus ruere, ac retro sublapsa referri. And yet with all our conscious efforts we cannot obtain such absolute unity of type as nature offers. The short-horns of two herds, the cinerarias from two nurseries, are never precisely the same, whereas not only from John O'Groat's house to Land's End, but from Greenland to Beloochistan, and from Siberia to Algiers, we shall find our friend the Chaffinch, undistinguishable in his dress, unaltered in his manner, and everywhere of the same sprightly carriage which has suggested to our friends across the Channel the happy phrase, gai comme pinson.

Can it be seriously maintained that all this is the work of chance, in the sense that it has been wrought out by mechanical forces apart from a plan? I think not: for 


\section{2 \\ "Behold the Birds of the Air"}

to set aside all other considerations, such a supposition would require us to believe that the circumstances which have operated to produce development have been as absolutely identical in all cases as are their results. Every bird precisely similar to another should be descended from a line of ancestors which had lived through just the same series of experiences as that other's. Yet it is almost impossible that in the case of any two broods can this be true; it is abundantly evident that, speaking of the race in general, it is the reverse of the truth. In no two of our own English parishes are the conditions of weather or of food-supply precisely identical; and if these had been the efficient causes, they should have availed to manifest their influence by varying at least the breadth of an edging or the shape of a spot. What differences of type might we then expect to find in Norway and in Palestine?

The example chosen is that of a bird so common that its observation is within the reach of all, but it is by no means either solitary or singular. The description of many others furnishes us with minutiæ of variations still more remarkable. Let the reader, the first time he has the opportunity, take a good look with a field glass at a Red-start, and observe the colouring of his head. He will find a narrow black band above the bill, a white patch on the forehead, the chin and cheeks jet black, the top of the head lead-grey. Again, to choose a subject which there will probably be more opportunity of handling, he may test upon the first Woodcock he falls in with, the following description of the bird by Yarrell :

"The beak is dark brown at the point, pale reddish brown at the base. From the beak to the eye a dark brown streak. The colour of the plumage is a mixture, principally of three shades of brown, pale wood-brown, chestnut-brown, and dark umber-brown; each feather on the upper surface of the body contains the three shades, but so disposed as to produce a beautifully variegated appearance. The cheeks pale wood-brown, 
spotted with dark brown; the forehead, to the top of the head, greyish brown; occiput and nape, rich dark brown, transversely divided into three nearly equal patches by two bands of yellow wood-brown; each feather of the neck below, pale brown, edged with dark brown; the back, greyish brown, varied with reddish brown and dark umber-brown; all the wing-coverts, reddish brown, with open oval rings of dark brown; primary quill feathers, blackish brown, with triangular spots of pale reddish brown along the margin of each web; secondaries and tertials of the same ground colour, blackish brown, but the light coloured marks are more elongated, and extend from the margin of the web to the shaft of the feather ; rump and tail-coverts, chestnutbrown, tinged with grey, and barred transversely with dark brown; tail-feathers, black above, tipped with pure dark grey; neck in front, breast, and all the under surface of the body, wood-brown, transversely barred with dark brown; both shades of brown on the under surface becoming lighter in old birds; under wing-coverts, pale brown, barred with dark brown; under surface of the quill feathers, day-slate grey, the triangular markings, yellowish grey; under surface of the tail-feathers, nearly black, tipped with delicate snow-white."

This I think is a very wonderful picture of a species to be drawn from one individual bought in Leadenhall Market; yet the Woodcock has a large geographical range, and must have been familiar with most diverse experiences, being found in Lapland within the Arctic circle, in Japan, in Cashmere, in Greece, in Barbary, everywhere the same, down to each triangular spot and open oval ring; arguing a permanence of type most strange in such variety of circumstances, and assuredly inexplicable by them.

Another question here naturally suggests itself upon which, important and obvious though it be, evolutionist writers do not sufficiently enlighten us. Are we to say that all the Woodcocks now existing have descended from one pair of Woodcocks, the first birds that ever 


\section{4 "Behold the Birds of the Air"}

attained that form ; or that through different and totally independent lines of descent precisely the same terminus has been reached? One or other it must be, but each answer would appear to involve grave difficulties. If, on the one hand, we say that all the members of the species are descended from one pair of ancestors, there is an end of the favourite Darwinian argument against the hypothesis of special creation, which rests on nothing more firmly than on the assumed impossibility of such descent. If, on the other hand, we adopt the supposition that Woodcocks have been the result of distinct developments, how account for the fact that the results are indistinguishable? As we have already seen, while, on Darwinian principles, it is circumstances alone which mould a species, the circumstances of no two breeds can be so exactly similar as are all the members of a species. How then shall we hold the circumstances to be the creative agency to which the species is traced? It is the fundamental article of Darwinism that there is no tendency implanted in organic nature ruling its development according to a definite plan: there is but a tendency to vary equally in all directions, as the steam in a boiler presses out equally at every point. What gives form to this shapeless force is the repressive action of Natural Selection, preventing development in all but a few directions; that is to say, external circumstances, not innate power, makes a plant or animal what it is. But if we say this we attribute to the one what we deny to the other. Grant that there was no tendency in the developing creature to become a Woodcock, and we must allow a tendency in the world around to make one, if it be indeed a fact that this complex pattern and no other will suit Nature's requirements, and avail for survival when those differing but a hair's breadth from it have been everywhere ruthlessly discarded. It is as easy as it is futile to amuse ourselves with vague general statements of the problem and airily to assume its solution. As we attempt to look more closely, we find, inadequate as our knowledge must be of the difficulties which in fact exist. 
that a swarm of fresh complications throw all our imagined machinery out of gear. The first developed Woodcock, for instance, must have had a host of kindred developed within one degree of himself. On Darwinian principles these must either have subsequently exactly followed his example, having hitherto failed exactly to follow it, or, failing to do so, must have been absolutely exterminated by competition with him and his progeny. Can we imagine that each and all of the minute artistic touches already described are so important to the bird's well-being, that their absence means a sentence of death? And if it does not, how comes it that this, and every other family of birds and beasts and plants, is not surrounded with a fringe of poor relations who have not succeeded in acquiring all its minor characteristics? Yet each species stands apart, as sharply defined as if struck from one mint. "Sports" there indeed may be within a species-albinoes or negroes or what not--but these do not perpetuate their peculiarities. Albino birds, it is said, never find mates, and the same is probably true of those tending to exceptional blackness. What we do not find is perpetuation of divergences from the exact specific type, and it is the absence of this which, on Darwinian principles, seems inexplicable.

In scientific investigations, as we are often told, the only sound mode of procedure is to see what hypothesis will fit the facts, and to prefer that which appears best to satisfy this requirement. If this be really done, can there be any doubt as to the nature of that force to which the phenomena we meet must ultimately be attributed? Has any answer but one been ever given to the straightforward question of Bishop Butler: "Will any man in his senses say that it is less difficult to conceive how the world came to be, and to continue as it is, without, than with, an intelligent author and governor of it?" I am much mistaken if the science whereof I have been speaking shall not lead him who studies it by methods truly scientific to bid the objects of his study to join with him in the glory of their Maker, recognizing, 
76 "Behold the Birds of the Air"

as he cannot fail to do, that whatever was the nature of the process, it was $\mathrm{He}$ who made them according to their kinds: and that if those kinds stand firmly established, in such bewildering variety, it is because $\mathrm{He}$ has blessed them, seeing that they are good. 


\section{Ibow Theories are IDanufactured}

WhEN the theatrical company commanded by Peter Quince took a hawthorn brake for their tiring-house, they put it to no unaccustomed use. Under its cover another band of performers, at least equal in merit, had, time out of mind, been wont to assume their liveries, before presenting themselves to the public eye. In the boughs above, or the brushwood and herbage below, the birds of the woodland had exchanged the callow deformity of nestlings for the elaborate costumes appropriated to the parts they were respectively to bear in the great drama of the seasons-the Redbreast and the Redpoll, the Black-cap and the White-throat, the Gold-crest and the Fire-tail,

The Ousel-cock so black of hue,

With orange tawny bill,

The Throstle with his note so true,

The Wren with little quill,

The Finch, the Sparrow, and the Lark,

The plain-song Cuckoo grey,

and all the rest of the tuneful choir. Each of these has, not only his special character, but a special dress to distinguish it, and to apprize us what to expect when he enters upon the scene; just as Duke Theseus and his court were to know that a man with plaster about him was going to do the work of a wall, and that another with a bush of thorns and a lanthorn was to "disfigure or present" the person of Moonshine. The piece in which these actors perform has had the longest run on record, yet is it ever new and full of novel v. 


\section{How Theories are Mamufactured}

interest to those who care to watch it. When that most delightful of books, Alice in Wonderland, was put upon the stage, the juvenile audience, who thronged to see it, joyously recognized for old friends each of the actors as they came on: "There's the White Rabbit, the Duchess, the Dormouse," was their cry; and the peculiarity of their pleasure was in seeing that done which before they had read about. In something of the same fashion we know the actors in Nature's serial story, and we know what they will do, yet always find it new in the doing. The Blackbird will, throughout the season, at evening, sound the curfew of the woods which the Hedge-Sparrow will echo with a modest accompaniment. The Robin, though his voice be drowned in the richer harmonies of spring, will make his mark as a musician, singing sweetly in the falling of the year. The Nightingale, "the liquid voice beloved of men, come flying over many a windy wave in days of budding April," will hold unchallenged supremacy amongst all choristers for about a month, and will then sink to the bottom of the scale, and be capable of nothing but an unmusical croak; while the diminutive Chiff-chaff, with his poor little ditty of two notes, will be in the field a full month earlier, and will go unwearied on three or four months later. The White-throat will babble and jar by the sides of hedges, every now and then darting vociferous up and down in the air, like a singing sky-rocket. The Sedge-warbler will chatter and prattle as he bounces about among the reeds and bushes of the water-side, and throw in mimicries of his feathered acquaintances. The Goat-sucker will purr the summer nights through on the moorlands, while the Corncrake complacently rehearses his interminable lay in the meadows, and the Snipe drums circling in the sky above. The Chaffinch will in winter be true to the ungallant habit that has gained him the specific name of "bachelor," cocks and hens consorting in separate flocks. The Rooks will leave their nesting-trees between

1 Fringalla calebs. 
the autumnal and vernal equinox to roost in large companies eisewhere, though for a short period ere the winter thoroughly sets in, they will come back and occupy themselves for some days in doing nothing about their properties. The Cuckso will open his lay in April, and alter it in June, as the old rhyme promises, and will play his singular rôle up and down the woodlands and meadows, giving Hedge-Sparrows and Pipits the charge of his offspring, which they will, as a matter of course, fatuously accept. The Gold-crest will weave his pendent nest with the same superlative art as he has ever done. The Bottle-tit will elaborate his pokepudding of a structure, and contrive to bring his dozen or more of youngsters out of it with their long tails all unrufflcd. The Willow-wren will build a domed nest on the ground, and the Jenny-wren a domed nest above it. The Thrush will plaster the inside of his, while Blackcaps will entrust eggs to so loose and light a structure as to make it seem mevitable that they will fall through, which, however, they will not. Swallows and Wagtails will mob approaching Hawks. Wild-ducks will be fascinated by the sight of a dog. All this and indefinitely more may be set down beforehand, and set down in the confident expectation of finding it performed. It is quite clear that the actors are cast for their various parts, and that somehow or other they have got those parts by heart, and have no notion of anything but duly going through them. And as it is clear that they do not improvise for themselves as the piece goes on, any more than they pick and choose, like Æsop's Jackdaw, what plumes they are to wear, men naturally set themselves to ask who or what it is that pulls the strings to which these multitudinous figures move.

This question scientific writers of the present day, or rather, perhaps, writers on scientific subjects, undertake with effusion to answer; and some of them are never weary of telling us how exceedingly simple a thing an answer is, since what they call the "illuminating" doctrine of evolution has been given to the world. But 


\section{8o How Theories are Manufacturex}

concerning the said doctrine, it seems high time that a clear understanding should be arrived at, and that we should be plainly told what it really does for us, and what it does not.

"Evolution," taking the word to stand for a scientific doctrine, signifies the theory that different kinds of creatures have developed from the same original, and that they have severally passed through sundry and various modifications in the process; that, for instance, the birds of to-day are descended from birds of other habits, whether we take the word to mean dress or conduct, and these again from animals, not birds at all, but lizards and fishes, and before these again something on a par with sand-eels and slugs, and so on down to "primitive Protozoa." Be it so, as perhaps it may be; for evolution does undoubtedly go on in the history, not of species only, but of individuals. Any one of the birds we see came into existence not as a bird at all, but as an egg, in which were contained none of those partsmuscle, nerve, or feather-which we now behold. The change from a Jelly-fish to an Eagle would not be one whit more wonderful than that from the yolk of an Eagle's egg. But what then? Evolution, at best, is but a fact; and what we want is not a fact but a force, which ten thousand facts will not supply, but only demand the more as their explanation. The locomotives which race to Edinburgh, and the marine engines which drive the greyhounds of the Atlantic, are both, no doubt, developments of the primitive machine which James Watt was called in to repair; yet we should hardly give an adequate account of the history of the steam-engine by merely stating this to be the case. What we want to know, and what evolutionists claim to tell us, is the active agent working through all the modifications that have been made, and in the development which has been the result. In the steam-engine, the improving agent has been found in the brains of various men: in the modifications of organic life it has been, according to evolutionists, the force of Natural Selecticn. 


\section{How Theories are Manufactured 8I}

This is undoubtedly the case; or else how are we to account for the position claimed for Mr. Darwin, as the Newton of organic science? Darwin did not originate the doctrine of evolution. Lamarck and others had championed it as stoutly as he. What he did was to offer explanation of a means by which evolution might have been governed and effected; to present what seemed a workable hypothesis to explain the process; and to state certain arguments in its favour. In other words, he professed to find the force responsible for the facts, and this force was Natural Selection. This it was that brought him into such prominence, for in this department preceding evolutionists had obviously failed to satisfy the laws of probability; while his inexhaustible patience in research, and his ingenuity in linking conditions and consequences, enabled him to present a sketch of Nature's method of procedure, which, within certain limits, might well be correct. It is true that it was only within certain limits, and that at best those limits were not wide. On the origin of life he could throw no light; while his very theory postulated a tendency in organic beings to reproduce their own likeness, with yet a certain tendency to variation, and variation in directions capable of advantageous development, and moreover of development towards a "higher" type. Given life, however, to start with, and such tendency to work upon, and it was hard to say, on first sight at any rate, that his system would not work; and it was speedily adopted as doing a great deal more. The limitations above indicated being tacitly ignored, it was speedily assumed that we had now, not as hypothesis, but as undoubted truth, the whole .philosophy of the world of life, and that evolution was at last proved, because Natural Selection would explain it.

But what is the case now? Evolution continues to sail under Darwinian colours, and to trade upon the approval which Darwin's great work gained for it, while meanwhile the vital principle of that work may be said to be already dead; for the explanation so ingeniously $\mathrm{v}^{*}$ 


\section{2 \\ How Theories are Manufactured}

offered has, by further inquiry, been discredited. The Natural Selection theory of the origin of things has lately been described, and so far as I am aware, without contradiction, as being no less extinct than the Dodo. An eminent man of science ${ }^{1}$ stigmatized the proposition that Natural Selection has originated species as "the most absurd of all absurd propositions." More than this, the case seems to be allowed to go by default against the theory, through the silence of its friends. A few years back, when, on occasion of the twenty-first anniversary of the publication of Mr. Darwin's book, a celebration was held to commemorate the coming of age of Darwinism, it was remarked as significant that not a word was said about Natural Selection. It would, in fact, appear that this theory is considered as a mere scaffolding, useful in running up the building, which may be quietly removed when that is completed. But so far as Mr. Darwin's contribution to science is concerned, and, moreover, so far as scientific explanation of evolution is concerned, it is not a scaffolding, but the central pillar upon which all the superstructure rests; and to talk of the system remaining unshaken aloft, though this has crumbled beneath, is like expecting the ball at the top of the Monument to hang suspended in the air should the shaft subside into a heap of broken stones.

But there is another point with which at present I am more directly concerned. While the Natural Selection theory is subject to attacks which its champions do not care to meet, it is still by a host of writers presented to the public as if in undisputed possession of the field. Those who deal only with what is known as popular science, will probably be surprised to hear any doubt cast on the sacred dogma, or on those romantic histories which are constantly written to glorify its cult, While scientific men of the first rank, who do not care to repudiate Natural Selection, are content to let it discreetly alone, there are many of a lower grade who

${ }^{1}$ Mr. St George Mivart in The Tablet, June 2, $\mathbf{3} 888$. 


\section{How Theories are Manufactured $8_{3}$}

cannot bring themselves to discard the weapon with which it seems to furnish them in their endeavour to demonstrate that the world is a clock which needs no winding, and that the potencies of matter are all-sufficient to explain the phenomena of life. Writers of this stamp are always ready to tell us all about it: to point a moral and adorn a tale from any object they meet in nature; the tale being the old one of development by Natural Selection, and the moral, that there is no Mind at work in the ordering of the world, and no controlling force except that Juggernaut-like engine, the struggle for existence, ever securing that the fittest only should survive while the weakliest go to the wall. It would be hard to match the calm assumption and serene selfconfidence of some of these writers, undertaking to unlock the secrets of nature, while in blank unconsciousness of the very existence of problems that stare them in the face. But even more than the mental attitude of individuals, a study of their productions illustrates the fatal facility with which fact and theory may be made to tally. It is with the common objects around us that such writers as Mr. Grant Allen-to take once more a conspicuous example - are wont to deal; and what I now propose is to observe in a few instances the method in which the work is done, and to ask a few questions as to the soundness of the result.

To come back to our birds, which I may seem in danger of forgetting. They, we are told, have acquired their present form, their plumage, and their habits, because these have partly helped to find their ancestors food, and partly to find them mates; and because, by the principle of heredity, the qualities, which have helped one generation to survive, have been perpetuated and made habitual in their descendants. Shape of beak and claw, development of muscle and of nerve, have served the one purpose; beauty of form and feather, sweetness of voice, and other æsthetic qualities, have served the other. But here at the first step a difficulty must needs crop up. Of what avail is external beauty of any sort, 


\section{How Theories are Manufactured}

or rather how can such beauty be conceived as possible, unless there be somewhere a sense of beauty to recognize it? Of what possible advantage can it be to a Wren to develop a golden crest, unless other Wrens think the feature pretty, when they see it? And whence came their taste in this regard, a taste that must have been antecedent to the first development, which would otherwise have been useless? On this point we are not likely to obtain any very clear information, the nearest thing to it which $I$ have succeeded in finding being an assurance that tastes of this sort are due to the creature's " environment," and that, in particular, bright colours in the food on which a species lives, are apt to be as it were reflected, through its tastes, in its plumage. Without diving deeper into the philosophy of the subject, let us see how far facts bear out this theory, and how far it is like the lamp in Christabel-all made out of the maker's brain.

"It is probable," we read in an evolutionary work, 1 "that an æsthetic taste for pure and dazzling hues is almost confined to those creatures which like Butterflies, Humming-birds, and Parrots, seek their livelihood amongst beautiful fruits and flowers." Such an assertion raises many questionings in a mind whose mood is philosophic doubt. Do not Bees frequent flowers as much as Butterflies? and the sad-coloured Humming-bird Hawk-moth as much as the Humming-bird? Are the seeding heads of thistles and knap-weeds so very brilliant as to account for the plumage of the Goldfinch? Is not the most lustrous of our British birds, without question, the Kingfisher, whose diet of minnows and loaches is as unlike as possible to that assigned to the tropical birds whom he so closely approaches? The Gold-crest, living in dull-coloured fir-trees, and feeding on insects, is robed in green and orange, while the Creeper, amid the same trees and hunting the same quarry, wears the soberest of sober garbs; the Woodpeckers live much like the Creeper, but dress in the fashion of Parrots, while

1 Grant Allen, The Evolutionist at Large, p. 195. 
the Grebes, which skulk among reeds and spend much of their life beneath the water, have a strong tendency for brilliant decorations, orange-red horns, chestnut crests, rose-tinted beaks, and green feet.

It would also be a not uninteresting subject of inquiry whether the colours displayed by fruit and flower in tropical forests, be really so pre-eminently brilliant as to account for the hues of the birds and butterflies whose lot is cast amongst them. Mr. Wallace, who so thoroughly explored the Malay Archipelago with its "gorgeous fruits and flowers," 1 tells a different story. "The reader familiar with tropical nature only through the medium of books and botanical gardens, will picture to himself many other natural beauties. He will think that I have unaccountably forgotten to mention the brilliant flowers, in masses of crimson, gold, or azure. But what is the reality? Not one single spot of bright colour could be seen, not one single tree or bush or creeper bore a flower sufficiently conspicuous to form an object in the landscape: there was no brilliancy of colour, none of those bright flowers and gorgeous masses of blossom so generally considered to be everywhere present in the tropics. I have given an accurate sketch of a luxuriant tropical scene, as noted down on the spot, and its general characteristics as regards colour have been so often repeated, both in South America and over many thousand miles in the Eastern tropics, that I am driven to conclude that it represents the general aspect of nature in the equatorial (that is, the most tropical) parts of the tropical regions." 2

Mr. Wallace goes on to ask and answer a significant question. "How is it, then, that the descriptions of travellers generally give a very different idea? and where, it may be asked, are the glorious flowers that we know to exist in the tropics? These questions can be easily answered. The fine tropical flowering-plants cultivated in our hot-houses have been culled from the most varied

${ }^{1}$ Evolutionist at Large, p. 19 r.

2 Malay Archipelago, vol. i. p. 37 I. 


\section{How Theories are Manufactured}

regions, and therefore give a most erroneous idea of their abundance in any one region. Many of them are very rare, others extremely local, while a considerable number of them inhabit the arid regions of Africa and India, in which tropical vegetation does not exhibit itself in its usual luxuriance. It has been the custom of travellers to describe and group together all the fine plants they have met with during a long journey, and thus produce the effect of a gay and flower-painted landscape. During twelve years spent amid the grandest tropical vegetation I have seen nothing comparable to the effect produced on our landscape by gorse, broom heather, wild hyacinths, hawthorn, purple orchises, and buttercups."

The splendid fruits fare no better at Mr. Wallace's hands than the gorgeous flowers. "Many persons in Europe are under the impression that fruits of delicious flavour abound in the tropical forests, and they will no doubt be surprised to learn that the truly wild fruits of this grand and luxuriant archipelago are in almost every island inferior in abundance and quality to those of Britain. Wild strawberries and raspberries are found in some places, but they are such poor tasteless things as to be hardly worth eating, and there is nothing to compare with our blackberries and whortleberries. The kanary-nut may be considered equal to a hazel-nut, but I have met with nothing else superior to our crabs, our haws, beech-nuts, wild plums, and acorns; fruits which would be highly esteemed by the natives of these islands, and would form an important part of their sustenance. All the fine tropical fruits are as much cultivated productions as our apples, peaches, and plums, and their wild prototypes, when found, are generally either tasteless or uneatable." 1

Evidence to the same effect, and directed to the precise point under consideration, is contributed by a correspondent of my own, from the Western tropics. Writing from the West Indian island of St. Vincent, he says : "A

1 Malay Archipelago, vol. ii. p. 103. 
few days ago I went up into the high woods; there are primæval forests, with all the luxuriance of vegetation one expects to meet in a tropical forest. I can safely say that in the course of many hours' walking I did not see one spot of bright colour. The tall trees, which exclude all sunshine, and the vegetation below, are of every possible shade of green, but that is all. Up to the edge of the forest, in the 'bush,' many wild flowers are now in bloom; but none of them are brilliant in colour-much less so than our English wild flowers: most of them are of a pale yellow, or washed-out lilac, almost grey. Every day I see Humming-birds feeding from flowers of a dull colour; up in the woods I saw many Parrots of a species peculiar to the island; their plumage is very bright, of the gaudy order of parrotdom, and at no time of the year can their surroundings help them to keep up their style of plumage. These are almost the only bright-coloured birds, except perhaps the Golding, a sort of heron, which is found in dark marshy bits by the rivers. The birds in the cultivated parts, where there are gardens and more show of colour, are almost all of dull hue."

From all this, it would appear, that our safest method will be to stick to our own landscape, about which we know something, and not wander off into tropical forests in quest of data for our hypotheses ; though, as we shall presently see, no object is so common and homely but that it may, in the interests of theory, be made the subject of a fairy tale. To pursue our researches, therefore, at home. After what Mr. Wallace has told us, we may, I think, conclude that in spite of the "bright orange and blue and crimson fruits in tropical forests" 1 nothing to be found there can compare with a Rowantree $^{2}$ in September, ladened with masses of coral-red berries. Yet what has been made of this glorious opportunity for colour education by the birds we find therethe Blackbird, the Ring-ousel, and the Missel-thrush?

${ }^{1}$ Vignettes from Nature, p. 86.
2 Or Mountain Ash. 


\section{How Theories are Manufactured}

Not one of them shows the smallest tendency towards "pure and dazzling hues." One is glossy black, another rusty black with a white gorget, the third speckled with various shades of buff and brown. Again, how is it that the various birds which devastate our cherries and currants should be of so dull hue compared with the Crossbill who, living on fir seeds, goes bravely in red and green? What again but the exigencies of theory could tempt a writer to say that the key to the comparative dinginess of the Blackcock is that he "does not feed upon brilliant food-stuffs, but upon small bog berries, hard seeds, and young shoots of heather," while "our naturalized oriental Pheasants still delight in feeding upon blackberries, sloes, haws, and the pretty fruit of the honeysuckle and the holly." 1 Any one who has walked a moor must know that cranberries and cowberries are quite as beautiful as those of the honeysuckle or holly, while the whortleberry is a fair match for the blackberry, which by the way also grows on hills, to say nothing of haws and sloes; and these various mountain fruits are supplied to the Grouse and Blackcock in far greater abundance than any æsthetic food to the Pheasant, which as a matter of fact, as farmers will sadly bear witness, prefers to anything else the grain of a wheat-field.

Again we are told that wading birds have had their æsthetic tastes turned into a "sculpturesque" line, ${ }^{2}$ and that they care for beauty of form, not for beauty of tint.

In support of this thesis, we are referred to "the Herons, the Cranes, the Bitterns, the Plovers, and the Snipes," with their various devices of crest and gorget and wing plume. But, even within the limits of the list furnished us, the Lapwing, a Plover, is surely a great deal more remarkable for his colour than for any exceptional grace of outline; while to go a little beyond it, the Woodcock is in shape comparatively clumsy, and

1 Evolutionist at Large, pp. 191, 94.

2 Vignettes from Nature, p. I05. 


\section{How Theories are Manufactured 89}

the Flamingo is anything but an instance of quiet coloration.

Again, take the large family of the Ducks. The habits and food of all are much the same, yet how extraordinary are the varieties of their colouring! The Mallard's head is green, the Pochard's chestnut, the Teal's chestnut with a peculiar green patch, the Sheldrake's is black, the Gadwall's grey. The Scoter wears a nearly uniform suit of sable, the Harlequin is spotted and striped, in accordance with his name. One duck is long-tailed, another is pin-tailed, a third is tufted. Most have a green speculum on the wing, in some it is white, others have none at all. How construct an explanation to reconcile all these varieties with the fitness of things? Who standing on the Bass, and seeing the myriad flocks of Gannets sailing above, around, and beneath, can imagine that the delicate shade of buff with which their heads are tinged is a consequence of their acquaintance with herrings and gurnets? The Jackdaw lives a life much like that of Rooks. How has his family and not theirs picked up a taste for a grey hood? The brilliant Yellow-hammer, bright as a Canary, is first cousin to the dingy Bunting, and lives in the same cornfields. The Pied Wagtail differs little in its habits from those whose prevailing hue is yellow. The Swallow has a red patch on the throat, and the House Martin a white patch on the back, though both lead the same life, and hawk after the same flies-in fact, so endless are the vagaries of plumage, that it would seem as feasible an undertaking to construct a philosophy of Paris fashions by computation of the planets, as to find an explanation of those of birds merely from the circumstances of their life. No one will, of course, deny that the circumstances in which they live have something, or rather very much, to do with their style of dress. We should not, on any theory, expect those who breed in open fields to be so brilliantly coloured as to attract the attention of every marauding Hawk or Stoat. No doubt Natural Selection would come into play to 


\section{How Theories are Manufactured}

stamp out any development of colour which in this way was objectionable and would thus affect colour negatively. The question is, whence comes the positive tendency towards coloration so abundantly manifested? To say that it is the result of "selective preference," on the part of other individuals, is to say nothing, till that preference be itself explained; for it needs explanation as much as the colour which it evokes. And what is true of colour is true of all other kinds of ornament.

In fact, in order to work their plan with any show of effectiveness, the writers of whom I speak have to beg the whole question. They are by way of demonstrating the truth of the Darwinian theory, and as a first step they assume its indisputable truth. This done, they proceed in a particular case to excogitate another theory as to how on Darwinian principles the organism could have come to its present form. This product of their fancy they set down as fact, and from this fact they invite us to confirm our faith in the great "illuminating" doctrine. That this is a fair account of the method of procedure no one will, I think, deny who has taken the trouble to sift the matter for himself; but to establish my assertion, I will take an example. What is true of colour in birds is true of it in flowers; the only difference being that the case of plants, the selective agency invoked is that of animals, benefiting those which please their eye, and thus aiding them in the struggle for existence. Sometimes it is insects which visit by preference a blossom of brighter hue, and so help to fertilize it: sometimes it is birds which, attracted by a conspicuous berry, help to disseminate its seeds. Amongst other plants with a conspicuous fruit is the Arum or Cuckoo-pint, known also as Lords and Ladies, a common and very noticeable growth along hedgerows in spring, which in autumn produces a bunch of brilliant red berries, like the rest of the plant deadly poison. The history of this plant's economy is cheerfully told by Mr. Grant Allen. "The Robins and small Rodents 


\section{How Theories are Manufactured 9I}

which eat the berries, attracted by their bright colour and pleasant taste, not only aid in dispersing them, but also die after swallowing them, and become huge manure heaps for the growth of the young plant." This gruesome little romance I have had occasion to notice in a former paper, ${ }^{1}$ wherein I ventured to propose two obvious questions: first, whether this remarkable arrangement has ever been verified in fact; second, how it comes, on principles of Natural Selection, that creatures so stupid, as the Robins would thus appear to be, have managed to survive in the struggle for existence. The author, since he first told the Arum's story in his Evolutionist at Large, ${ }^{2}$ has somewhere been confronted by questions to the same effect, which, in a later work, Flowers and their Pedigrees, he notices. ${ }^{3}$

After recounting the murderous tale substantially as before, he proceeds thus to qualify his former categorical account. "I will not positively assert that it is for this reason the Cuckoo-pint has acquired its poisonous juices; but I cannot help seeing that if any berry happened to show a tendency in such a direction, and so occasionally poisoned the creatures which eat it, it would thereby obtain an advantage in the struggle for existence, and would tend to increase the poisonous habit so far as it continued to obtain any further advantage by so doing. . . Poisonous berries are unquestionably useful to the plants which bear them. ... It is impossible, in fact, that a plant should not benefit by having its berries poisonous, and so some plants must necessarily, in the infinite variability of nature, acquire the property of killing their friendly allies."

Here, then, habemus confitentem reum: the pathetic story Mr. Grant Allen has told us as to who killed Cock Robin is exactly on a par with the veracious

${ }^{1}$ See Essay on Mr. Grant Allen's Botanical Fables.

2 P. 86.

${ }^{3}$ P. 263. The italics are mine. 


\section{How Theories are Manufactured}

ballad of our childhood, neither more nor less : ${ }^{1}$ it is an evolution of Darwinian fancy, not a sober record of observed fact. Such are the feats which we are able to perform in the fields of science, who have the good luck to live " since the great principle of descent with modification has reduced the science of life from chaos to rational order;" we who "can now answer confidently: Such and such a plant is what it is in virtue of such and such ancestral conditions, and it has been altered thus and thus by these and those variations in habit or environment." 2 Confidence there assuredly is, enough and to spare, in the story told us, but whether, all things considered, such confidence constitutes scientific merit is quite another thing.

The answer elicited to the other question is no less wonderful though in another way. "It has been asked why the birds have not on their side learnt that the Arum is poisonous. The very question shows at once an ingrained inability to understand the working of Natural Selection. Every bird that eats Arum-berries gets poisoned: but the other birds don't hold a coroner's inquest upon its body, or inquire into the cause of death. Naturally the same bird never eats the berries twice, and so experience has nothing more to do in the matter than in the famous illogicality about the skinning of eels." 3 No doubt this reply is in true philosophic vein ; and unquestionably "ingrained inability" is good. But,

1 This nursery rhyme might be re-written in the scientific spirit for the benefit of children of the future ; thus-

Who killed Cock Robin?

I, says the Arum,

My fruits ensnare him :

I killed Cock Robin.

Who saw him die?

I, says Darwinian:

It's my opinion :

I saw him die.

2 Flowers and their Pedigrees, p. 2.

3 Ibid. p. 264. 


\section{How Theories are Manufactured}

with all due deference to a passed master of the craft, it may be asked whether he himself has in this instance quite understood the action of Natural Selection. The question is not what the birds think, but what nature does : not of a coroner's inquest, but of the survival of the fittest. Naturally the birds which gobble down poison for food will die, and as a necessary consequence will have no more children; while those they have already had, if they imitate their parents, will perish like them, and bring their race to naught: or if they do not imitate their parents, will produce a new and circumspect generation, in face of which the malign vegetable will, like the Moor of Venice, find its occupation gone. To argue according to the model we have already seen : it is impossible that a bird should not suffer by a habit of eating poison, and some birds must necessarily have been exterminated by their treacherous entertainers.

The plain fact is that the whole thing is too absurd for serious discussion, were it not that so large a number of readers would appear to take such histories for serious contributions to science. The writer with whom I have been engaged produces book after book and article after article, in a fashion which bears witness to his popularity: he is enthusiastically praised by such men as Mr. Clodd, 1 and if report speaks truly, patronized by Mr. Herbert Spencer: he is chosen to write the sketch of Darwin in the English Worthies series, and there he proclaims, as he everywhere indicates, his championship of the crudest and baldest materialism, and his devotion to the creed of "evolution as a cosmical process, one and continuous from nebula to man, from star to soul, from atom to society." 2 In view of all this it becomes imperative to examine thoroughly the real claim of his works to the position they affect to fill.

But it is not only in this fatal facility of imagining,

1 "As Grant Allen shows in his delightful and exhaustive book on the colour sense," \&c. \&c. \&c. (Clodd, Story of Creation, p. 90 ).

${ }_{2}$ English Worthies: Darwin, p. 191. 


\section{How Theories are Manufactured}

that such guides are apt to prove misleading: grant all their facts and the processes of what they call their reasoning are still more extravagant. To come back to the matter which has so long detained us. Suppose it be a fact that birds acquire their taste for bright colours by feeding on bright fruits: whence, then, did the fruits get their brightness? Strange to say, from the same birds! So at least, most emphatically, does Mr. Grant Allen inform us: "These fruits were specially coloured to allure their eyes, just as Speedwells and Primroses and Buttercups are specially coloured to allure the eyes of Bee or Butterfly." 1 "Birds have a quick eye for colour, especially for red and white: and therefore almost all edible berries have assumed one or other of these two hues." 2 "For this end, just as so many flowers have bright-coloured petals to attract the eyes of insects, we know that fruits have bright-coloured pulpy coverings to attract the eyes of birds or mammals." 8 Surely for a system that undertakes "to reduce the science of life from chaos to rational order," this is the most admired confusion that ever was. The birds acquire from bright fruits that taste, which they must have, to make the fruits bright; and wherever we shall conclude that beauty of hue first appeared, sense of such beauty must, on Darwinian principles, have preceded it. Everywhere in fact apparent dira facies: the Absolute looms before us. Once grant that there are things beautiful, and we must come to a canon of beauty, which they did not make: just as from the acknowledgment of truth, as such, we must come to Truth that is eternal, and by talking of creatures "higher" and "lower" in the scale, we implicitly confess to a type of perfection.

It is all very well embarking with a light heart on an uncomprehended enterprise, to tell us that no conscious purpose has been at work to produce what we admire, but that man, recognizing in the work of Nature those

1 Vignettes from Nature, p. 86.

2 Evolutionist at Large, p. 22.

3 Flowers and their Pedigrees, p. 263. 


\section{How Theories are Manufactured 95}

elements of beauty with which he is familiar, in the handicraft of his own kind, proceeds to "read in" an intention, and to fancy that Nature, or whatever that word represents, had an artistic end in view. If man recognizes beauty when he sees it, no matter where, and if his recognition corresponds to a reality, then he has a sense, which, till it first met with a beautiful thing, could in no way be accounted for by circumstances. Just as the idea of colour must have been existent to evoke coloration, so the idea of beauty must be in the mind that picks out one object or one arrangement as more beautiful than another, and selects it for reproduction. It might seem therefore that judgment in this matter goes by default. On the one hand we have no experience of artistic work as the product of anything but artistic purpose. On the other hand we find artistic work in Nature, vastly superior in merit to our own, and we find no possible motive to explain it in any blind mechanical machinery. Is it unreasonable to trace in it a purpose like in kind to that of which we are conscious in ourselves?

But this is not all. We have not to go far in the records of observation to find distinct evidence of an immanent purposive tendency, working in nature in definite directions. It is certainly not from what we see, that we learn to describe the tendency to variations in plants and animals as being merely centrifugal, like the expansion of a gas. On the contrary there are clear indications of a something in the organism itself guiding definitely in one direction. To illustrate this by examples It has been said that the tribe of Birds of Paradise seem to have an innate tendency to vary in the direction of beauty, a tendency satisfied in such diverse modes as to preclude the notion that they have all been hit upon, within the limits of the same family, by blind accident. Now one set of feathers and now another are wonderfully developed and coloured. In the Six-shafted Bird it is those of the head that form its peculiar ornament, being lengthened into slender wires with a small oval 


\section{How Theories are Manufactured}

web at their extremities : the Great Bird has a dense tuft of golden-orange plumes beneath the wings, two feet in length: the Red Bird has the two middle tail feathers transformed into stiff black ribands twenty-two inches long, forming a graceful double curve: the Magnificent Bird has a mantle of straw yellow springing from the nape of the neck: the Superb Bird a bluish green shield on the breast and a large shield of velvety black from the back of the head. These are but a few; but as Birds of Paradise frequent tropical forests I prefer to seek for traces of the same sort of thing among the denizens of our own woods. The nearest akin of these to the Paradise group are the Starlings and Crow tribe, and amongst them we find a distant reflection of the brilliant metallic colours which their far off relatives affect, and a modest imitation of their variety of decorative device. The Starling itself is one of the handsomest of our British birds, its dark plumage glossy with purple and green reflections; its rose-coloured cousin, the Pastor, has the neck and throat violet-black, the wings and tail metallic greenish black, while the back and breast are tinted with the hue whence it takes its name. The Crows, closely allied to the Starlings, in spite of the deep mourning into which their best-known representatives have permanently gone, exhibit the same tendency, in the lustrous reflections of their feathers; the Magpie has developed a long tail iridescent with greenish bronze, and has glossed the dark portion of its remaining plumage with green and violet: while its next of kin the Jay, discarding metallic lustres altogether, supplies their place by the elegant crest of the head, the delicate wine-brown of the nape and back, the beautiful arrangement in black, white, and blue on the winglet and greater coverts.

Something of the same sort is to be seen amongst the Woodpeckers. They again as a family have a taste for splendour, but it is a splendour quite distinct in kind from that of the Corvida, and quite distinct in its developments among Woodpeckers themselves. The 


\section{How Theories are Manufactured}

Green Woodpecker, "the garnet-headed Yaffingale," adorns his head and nape and the corners of the mouth with crimson. The Great Spotted Woodpecker is chiefly black and white, but crimson on the nape and under tail coverts; the Lesser Spotted Woodpecker has a crimson crown; and the Great Black Woodpecker, though otherwise sable as a crow, reveals the family taste in his blood-red cap. Another well-marked family, with decided proclivities, are the Titmice, their plumage brightly painted according to a chromatic scheme of their own, eschewing gaudy hues. The Great Tit is in blue and yellow, with a black cap and white cheeks, and a narrow black stomacher. The Tomtit, too well known to need description, with his cobalt coloured crown, and blue, green, and yellow tints of back, breast, and wing, shades off our British species into the ultramarine and azure tits of the Continent. The Cole Tit on the other hand discards the blues and yellows altogether, but is artistic in his treatment of black and white. One Tit develops a crest; another a pointed black moustache. To the Grebes I have already alluded. The Loon has a crest and ruff of dark brown and chestnut; the Sclavonian Grebe has a bushy black ruff and two orange-red horns; the Eared Grebe has, above and behind each ear, a tuft of loose reddish chestnut feathers. Even the modest and retiring little Dab-chick, Shakespeare's

Didapper peering through a wave

Who, being looked on, dives as quickly in,

cannot forego the scrap of finery supplied by a lurid red tint about the throat. What has been already said about the Duck tribe may serve in this connection for them likewise. No one who has made personal acquaintance with the family of the Chats and their kindred, Stonechats, Whinchats, Wheatears, and Redstarts, can fail to note the unity of decorative idea which they exhibit in their diversities; and the same may be said, in greater or less degree, of the Wagtails, the Linnets. 


\section{How Theories are Manufactured}

and the Doves, and still more markedly of the Herons and Cranes.

In face of all these examples, it seems hard to conceive that there is not an internal directive force guiding development, if development there be, along predetermined lines, and not leaving it to find its way, fortuitously, like a butterfly in a hailstorm, between the blows of destructive forces.

It is likewise perhaps worthy of remark that although brilliancy of colour is as a rule most conspicuous in the breeding plumage, it sometimes manifests itself at a season when the selective preference of a mate cannot account for its genesis. The Redpoll, for instance, in spring, has but a faint tinge of crimson on its forehead, which develops in richer tints as the season advances to the time of the great moult which follows; being thus at its best when the breeding season is done. A phenomenon of similar import is presented by the autumn song of the Robin, which cannot be accounted for, like spring melodies, by the advantage which it gives the singer in securing a partner.

But this threatens to lead me to the question of manners and customs, another branch of my subject, of even wider and deeper interest, which I had intended to treat in this paper, but which, spatiis exclusus iniquis, I must leave for another.

Before passing from the question of colour, however, some mention should be made of the solution recently proposed by Mr. Wallace. In his opinion the Darwinian explanation of the origin of decorative coloration, through the selective agency of mates, is not the true one ${ }^{1}$ and in its place he suggests another, which, truth to tell, is still less comprehensible; here, in fact, as elsewhere, his argument is not merely hard to follow, but absolutely eludes perception. $\mathrm{He}$ calls atiention ${ }^{2}$ to the fact that diversified coloration follows the chief lines of structure, and changes at points, such as the joints, where function changes. Thus among mammals

1 Darvinism, pp. 274-288.

${ }^{2}$ P. 288 , 


\section{How Theories are Manufactured 99}

stripes often follow the lines of the spine and ribs, the shoulders and hips are marked by curved lines, and emphatic coloration picks out the extremities of ears, feet, and tail. Among insects the same sort of thing is noticeable. In butterflies, the spots and bands usually have reference to the form of the wing and the arrangement of the nervures. Even in birds the distribution of colour and markings follows generally the same law. The crown of the head, the throat, the earcoverts, and the eyes have usually distinct tints in all highly-coloured birds, and distinct patches of colour are frequently situated on special centres of muscular action, as on the breast and the root of the tail. Mr. Wallace also points out that special brilliance of coloration often accompanies other symptoms of more than ordinary vigour. "Brilliant colours," he says, " "usually appear just in proportion to the development of tegumentary appendages. Among birds the most brilliant colours are possessed by those which have developed frills, crests, elongated tails, expanded wings, or plumes," like the Humming-birds, Peacock, Argus Pheasant, or Birds of Paradise respectively. So, too, among insects the most gaudy are those which have the most expanded wings, as Butterflies, Moths, and Dragon-flies.

Here is an interesting collection of facts-if, indeed, the general proposition itself be a fact ${ }^{2}$-but what then? Where is the "explanation" of coloration which these facts afford? Apparently we are to understand that vital vigour produces colour, and that where the former

1 P. 290.

2 The fact for which Mr. Wallace contends seems to require large deductions. Among birds the ornamental bars of the wings and tail generally run across the line of their structure and do not follow it. Moreover, the most beautiful effects are produced by differences of hue in each individual feather. Our brightest British Birds, as the Kingfisher and the Goldfinch, develop no crests or appendages. The Pheasant develops a long tail, but it is sombre in colour in comparison of the neck and back. Moreover, the theory seems to deal only with brilliant coloration and to afford no explanation of the not less beautitul effects produced by delicate shading, as in the Woodcock or Partridge. 


\section{Ioo How Theories are Manufactured}

has a free hand the latter will appear. But is this more than to say that animals clothe themselves in colour because, in the much criticized words, "it is their nature to "? Because Homer and Milton showed their strength of constitution by living to be old men, shall we say that the production of the Iliad and Paradise Lost is by that fact sufficiently explained? It would seem to be much the same sort of an argument to say that because a Peacock develops so stately a train we understand how that train comes by its complicated spangles.

Here I must stop, but enough has, I think, been said to show that, as Mr Balfour has it, "1 "although Evolutionists also find themselves occasionally amongst the prophets, some of their theories are conceived in the spirit of prophecy, rather than in that of natural philosophy."

1 Address to Church Congress, 1888. 


\section{Zngtínct and its $\mathfrak{L}$ esgons}

Who taught the nations of the field and wood To shun their poison and to choose their food? Prescient, the tides or tempests to withstand, Build on the wave, or arch beneath the sand?

Who made the Spider parallels design, Sure as De Moivre, without rule or line? Who bid the Stork, Columbus-like, explore Heavens not his own, and worlds unknown before?

Who calls the council, states the certain day, Who forms the phalanx, and who points the way?

(Essay on Man, iii.)

Mr. Pope was, clearly, in no doubt as to the answer, when he framed his question in such terms as these. The Darwinian bard, supposing him to be evolved, will ask, not who, but what has ordered Nature thus; and will call on science to reply that the blind selection of unconscious force has framed all laws we trace in Nature's course. What does Nature herself say? On which side does she give evidence?

If through any of her phenomena she bears witness to a plan consciously designed for definite ends, her voice would appear to be most clear and emphatic in the phenomena of instinct. There we find abundant traces of a force acting with a purpose, which yet is not the purpose of the immediate agents: we find creatures obviously deficient in the very elements of that power, by which we have to solve every problem of our life, yet solving some determined problem, it may be of extraordinary intricacy, with a facile precision, to us wholly incomprehensible; powerless to originate the least shred vi. 
of fresh design, but striking out that which is native to them, with the unhesitating accuracy of a planet describing an ellipse. The force guiding such operations is what we describe as instinct. Round this term many controversies have raged, and rage still, and not least as to its definition. For present purposes it may be sufficiently described as a guiding light directed to a practical conclusion, but not by means of premisses : telling the what, but not the why: guiding correctly, but not supplying the knowledge on which alone could a correct judgment rationally be based.

That there is such a guide can hardly be denied. What man could do only with much elaborate training, animals do unhesitatingly and at once; and while it is simply out of the question to suppose that they have the conscious knowledge by which he would have to steer, they arrive at the goal by a straighter and surer path:

Sure never to o'ershoot, but just to hit,

While still too wide or short is human wit ;

This, too, serves always ; Reason, never long;

One must go right ; the other may go wrong. ${ }^{1}$

To give in illustration an oft-quoted example. Wasps of the genus called Sphex lay up with their eggs a store of animal food for the benefit of their young when hatched. It is desirable, from their point of view, that the victim chosen for this unhappy function, should be rendered helpless, but at the same time not killed, that so the provisions may keep fresh. This is effected by stinging him in one or more nerve centres, thus paralyzing him for motion, but not immediately affecting his life. One species of Sphex, for instance, preys upon Crickets, in which three nerve centres have to be thus dealt with, to reach one of which the neck has to be stretched back, while the others are minute spots in other parts of the body. For a man to do this would require the nicest knowledge of anatomy. Yet the Sphex performs the operation with unhesitating accuracy.

1 Pope, Essay on Man, ii. 
and a young mother doing so for the first time cannot be guided by experience, while she certainly has not an elder instructor at her elbow.

From examples such as this, which is but one out of thousands, it would seem, as I have said, to be quite clear, that the actions of animals exhibit a purpose, which is not their own. The Wasp cannot deliberately intend to pierce a nerve she has never seen, and of the functions of which she has no knowledge: but her action accurately serves to attain the end of propagating her race. For Darwinism, however, this is a matter of life and death: if there is purpose in Nature, it is all over with the supremacy of Natural Selection. It is not, therefore, to be supposed that the point will be tamely yielded, and as a matter of fact, great pains have been taken to show that purpose is not a necessary part of Nature's machinery.

It is contended that in this department also, as well as in bodily outfit, Natural Selection has been sufficient to produce and to perpetuate those habits which are beneficial to the race. As Mr. Darwin himself puts it, ${ }^{1}$ his restrained and scientific tone contrasting agreeably with that of many among his disciples: "It may not be a logical deduction, but to my imagination it is far more satisfactory to look at such instincts not as specially endowed or created instincts, but as small consequences of one general law, leading to the advancement of all organic beings, namely, multiply, vary, let the strongest live and the weakest die."

How this idea is worked out is not very easy to explain, for, with all desire to understand the expositions of its advocates, I have found them thard to grasp. I think, however, that the following is a fair description.

Whatever in the way of instinct is beneficial to the race, enabling its representatives to survive in the struggle for existence, has been handed on, and developed in the handing, by the hereditary principle, from parents to offspring. Given that a beneficial habit was once 1 Origin of Species, p. 24+. 
acquired, there is no difficulty in its perpetuation. And just as sharper claws or a longer beak may have been produced by the survival of individuals whose organs chanced to vary in such direction, so the migratory instinct of the Swallow, the architectural skill of the Chaffinch, or the surgical accuracy of the Sphex, may be accounted for.

It is obvious that whatever truth be conceded to this statement of the matter, it does not take us very far on the road to an absolute explanation. Just as the Natural Selection theory requires life to begin with, and capability of variation to work upon, so this hypothesis by which instincts are to be explained demands instinct to start with, and instinct, moreover, capable of development. It is of no avail putting an egg into an incubator, unless that egg contains a germ which the fitting conditions of ventilation, moisture, and warmth, will develop into a chick; nor can an instinct be hatched by any combination of circumstances except from an instinctive principle. Yet on the origin of such principle $\mathrm{Mr}$. Darwin emphatically assures us, he can throw no light. "I must premise, that I have nothing to do with the origin of the primary mental powers, any more than I have with that of life itself." 1 At this point therefore we are, on any theory, stopped short by a great gulf, which our reasonings cannot pass, and in our explanation of what seems mysterious we must perforce leave untouched the greatest mystery of all. This only is allowed us, striking the track on the verge of this infinite void to follow it through the fields of nature, and to search out the conclusion to which it leads. "We are concerned," Mr. Darwin tells us, "only with the diversities of instinct and of the other mental qualities of animals within the same class.

Without at present stopping to examine this most important limitation of the field, let us see what there is left for us to explore. Prescinding from the question of their origin, does Natural Selection sufficiently explain

1 Origin of Species, p. 207 
the production of such instincts as we find actually in operation? Can we suppose that the multiform habits we find among the brutes, have all been beaten out of the primordial instinctive germ by no agent of more directive tendency than the sledge-hammer of destructive forces? This question resolves itself into two. Is it conceivable that the habits now instinctive, originated in fortuitous acts $;^{1}$ acts which proving advantageous have by Natural Selection been perpetuated as habits? In the next place, granting it possible that blind forces should have elaborated machinery so complicated as some habits exhibit, could those habits descend from one generation to another, unless there were in a creature's very nature something inducing the descent?

Both these questions Darwinians answer in the affirmative. To employ again the example already brought, they say that the instinct of the Sphex is sufficiently accounted for by the possibility that one of its ancestors had the luck to hit upon just the proper nerve to sting, ${ }^{2}$

1 Objection will probably be taken to this term fortuitous. It will be said that there is no such thing as chance; that if a stone cast at random hits a Swallow, given the path of stone and bird, their impact is not fortuitous but necessary. Of course it is; but that does not eliminate the fortuitous coincidence of the paths, creating the necessity. Chance is the coincidence of independent phenomena; phenomena not co-ordinated to an end. The action of rain and frost, weathering the surface of a stone, must produce in it some shape or other; but should a bust of Napoleon result, the likeness would be due to chance. If the phenomena of development and external force be not determined towards the survival of certain forms, their survival is fortuitous. If the phenomena be so determined, then chance vanishes; but so does, likewise, the Darwinian hypothesis.

2 There is indeed another explanation offered : that of "lapsed intelligence," thus stated by Mr. Romanes (Mental Evolution in Animals, p. 30I): "I can see no alternative but to conclude that these wasp-like animals owe their present instincts to the high intelligence of their ancestors, who found from experience the effects of stinging thus, and consequently practised the art of stinging till it became an instinct." In spite, however, of the high scientific authority of its advocates, it will seem to most readers that such a theory does not demand to be seriously discussed. 
thereby scoring a point in the game of life; and that this act, grown into a habit, has been handed on by Natural Selection, improving as it went, to the Sphex of to-day.

Now it is quite evident that so far as the ultimate treatment of the matter is concerned this theory does not strictly touch the question of purpose at all. Purpose may well lie hid in that first embryo of instinct of which we have perforce to take no account, but in which so much was obviously contained. To say that we could find no working of purposive design in all after developments, would be only on a par with saying that we could find no vital principle in a tree but only in its roots. This is sufficiently obvious, yet it appears sometimes to be forgotten. It seems to be not unfrequently assumed, that granting the possibility of such habits having fortuitously originated, and having been handed down by descent, the whole question is solved. But surely not. Everything else being surrendered there remains that first spark of instinct with which we all must start, and that spark must be capable of development, or we could none of us proceed. This very capacity of development though. it were only vaguely and equally in all directions, would still be inexplicable without a design which its development should accomplish. We do not therefore completely explain instinct by calling it inherited habit; it is not an explanation merely to give a thing a name. A habit, by its very essence, demands something whereof it may be a habit; it is of necessity a parasite, growing upon something else, and upon something else from which it can draw its vitality. Let all instinct now existent be inherited habit, that does not take away the need of a first instinct that was not a habit but was capable of forming habits. If there be not such an original to build habit upon, habit there could not be; we might as well expect to get fruit by grafting an apple upon a milestone.

It is a still more obvious consideration that the number of instances in which instinct has been handed 
down, in form of habit, does not in the least impair the necessity of a basis wherefrom the first impulse might start. Archimedes might have moved the world could he but have found a fulcrum, and Nature's machinery, however complex it be, and however remote its ramifications, must, no less than his, depend for its power of doing work upon the basis, whereby it is upheld. Once get habit solidly mounted and no doubt it may transmit its forces, but being habit it cannot be its own foundation.

Thus much premised, let us explore the narrower territory in which Darwinism claims to reign. And first we have to inquire whether it be a tenable hypothesis that the instinctive habits, which we witness amongst the brutes, had their origin in what we describe as fortuitous acts. On this question there is no need to dwell at length. Darwinians assert that this hypothesis is conceivable. Let us take a few instances, and ask ourselves to conceive it.

Without again recounting the story of the Sphex we may refer to it once more in this connection. The instinct here manifested is by no means without a parallel, it is not even the most wonderful of its kind. Another species of the same genus uses Caterpillars instead of Crickets, and to paralyze them from six to nine stings are needed, one between each of the segments of the body, the brain being also partially crushed by a bite with the mandibles. Another species of Wasp, Tachytes, uses Grasshoppers in a similar fashion, and to reach the desired nerve has to bend forward the victim's head and bite through a membrane, but if Grasshoppers fail it will take a Caterpillar. The Ampulex prefers Cockroaches, but will make a shift with other insects: the Stethorectus chooses Spiders by preference, even the huge Bird-spider which devours Humming-birds, but can do with Grasshoppers and Caterpillars. An instinct fundamentally the same is occasionally found in animals altogether different. Thus there have been found in a Polecat's nest as many as forty 
Frogs and Toads, all alive and able to sprawl helplessly, but each bitten accurately through the brain, so as to incapacitate them for locomotion. ${ }^{1}$ The devices of the Wasps I have mentioned are paralleled by those insects on which they practise. Thus a Spider in whose web a Beetle had been entangled, and who was in trouble with so boisterous and unruly a prey, has been observed to bite through one of the fore-legs; the Beetle then bending its head to soothe the injured limb, the Spider quickly passed a thread round its head, and bound it down in a position that made further struggle hopeless.

Insects that live in community, as Bees, Wasps, and Ants, need the most complicated machinery of instinct, that their polity should stand. The individual members must be willing not only to work, but to work for others, and not for themselves, and they must be respectively ready for the diverse functions assigned to them. To quote Réaumur, "Hardly are all the parts of the young Bee dried, hardly are its wings in a state to be moved, than it knows all it will have to do for the rest of its life. It seems to know that it is born for society. Like the others it leaves the common habitation, and goes in search of flowers. It goes to them alone, and is not embarrassed to find its way back to the hive. If it goes to draw honey, it is less to feed itself than to commence its labours for the common weal, for, from its first journey, it sometimes makes a collection of wax. M. Maraldi assures us that he has seen Bees return to the hive loaded with large balls of this substance the same day they were born." 2 To estimate the practical skill which a wax-worker Bee requires we must remember that the form of his cell is exactly what it should be, to give a maximum of strength and capacity with a minimum of material, and that to calculate this form mathematicians have to propose to themselves the

1 Magazine of Natuiral History, vol. vi. p. 206. Quoted by Mivart, Lessons from Nature.

2 Réaumur, Hist. des Insectes, t. v. mem. xi. 
following problem: "To find the construction of a hexagonal prism terminated by a pyramid composed of three equal and similar rhombs, such that the solid may be made of the least quantity of materials."1 This problem resolves itself into another, namely, what should be the angles of the rhombs that cut the hexagonal prism, so as to form with it the figure of least possible surface. The value of the angles as found by the Bees, and correctly found, are $109^{\circ} 28^{\prime}$ and $70^{\circ} 32^{\prime}$. Also the working Bee must have the power, by whatever process acquired, of striking perfect circles from centres, the distance of which from each other must be accurately adjusted, and the centre of the circle drawn on one side of the comb must be equi-distant from the centres of the three adjacent circles on the other side: a problem which man would find not altogether easy, even though armed with compass and rule. It has been confidently argued, against the obvious inference to be drawn from these facts, that the form and arrangement of the Bees' cells naturally result from the manner in which they set about their work. But the answer is obvious; how did they learn so to set about it? On the whole it is not, I think, an unfair statement of the case, that, either a most delicate mathematical problem is solved by every Bee that makes a cell, or the problem has been solved, once for all, for every Bee before it was born.

Bees and Wasps perform from their own resources the various operations necessary for the public weal, waxworking, honey-storing, cell-construction, and nursing of the larvæ. It is not so with all social insects. Some Ants have another instinct that prompts them to engage in the slave-trade. One of our English species (Formica sanguinea) does this at the expense of another (Formica

1 The problem was proposed in this form by Réaumur to König, who calculated the angles as $109^{\circ} 26^{\prime}$ and $70^{\circ} 34^{\prime}$. Further calculation has shown that the trifling error was on the side of the mathematician, or rather on the table of logarithms he used. See the Encyclopadia Brilannica (last editios), article "Bees."

$$
\text { VI.* }
$$


fusca). The slaves, as Mr. Darwin tells us, "habitually work with their masters in making the nest, and they alone open and close the doors in the morning and evening." They also search for Aphides. A continental Ant (Formica rufescens), which likewise makes slaves, has lost all power of any work except slave-making. The males and females of this species do no work at all; the neuters, or workers, though most energetic and courageous in capturing slaves, do nothing else. The slaves have to make the cells, tend the larvæ, feed their masters, and, in case of migration, also to carry them. The slave Ants are thus possessed of an instinct altogether unselfish, one which does not in any way tend to the good of their own kind, for it is most noteworthy that the slaves are all neuters, which can do nothing to hand down instinct of any sort: while the dusky race, of which slaves are made, show their sense of the blessings of slavery by fierce battles to avoid it, when a party comes marauding.

Creatures such as insects are in some respects the best in which to study instinct, as in them we find it most remote from reason. While such animals are obviously incapable of framing a judgment, their operations yet exhibit a minute accuracy which we do not meet elsewhere. We find examples, however, of much the same import, among brutes of higher development. The architectural work of the Bee may to some extent be matched by that of the much-abused Mole. This underground engineer has played a part in English history, and for his share in bringing about the death of Dutch William he used to be toasted by Jacobites as "the little gentleman in black velvet." This, however, is not his earthwork's only claim to admiration. Though endowed with eyes so imperfectly developed as to make it doubtful whether he can really see, and though his whole life is spent in laborious search for food, a fast of six hours being said to be fatal, this animal exhibits in its engineering operations the most consummate skill. In the centre of his estate, for each Mole claims a certain district 
as his own, he constructs his fortress, thus described by Mr. Bell: "The fortress is formed under a large hillock. It contains a circular gallery within the base, which communicates with a smaller one above by five nearly equi-distant passages; and the domicile or chamber is placed within the lower and beneath the upper circular gallery, to which it has access by three similar passages. From the chamber extends another road, the direction of which is at first downwards for several inches; it then rises to open into the high-road of the encampment. From the external circular gallery open about nine other passages, the orifices of which are never found opposite to those which connect the inner and upper gallery; these extend to a greater or less distance, and return into the high-road at various distances from the fortress." 1 Thus the chamber communicates downwards directly with the higher road and upwards with the upper gallery, which again communicates by five passages with the lower, and this again with the road by no less than nine, affording an elaborate system of escape. The high-road, so often mentioned, extends from the fortress to the extremity of the domain, and from it run on each side the alleys which lead to the hunting-ground. The architectural craft of the Beaver has been so often described that I need do no more than allude to it in this connection.

An instinct of quite another kind, but in which it is equally difficult to trace a fortuitous origin, is that exhibited by the Wild Duck in her efforts to decoy an intruder from her young. So well is the game played as to deceive a person who is familiar with it in books. An angler, for instance, is wading up stream among the hills, when suddenly, as he turns a corner, out flops from under his feet a Duck, one wing dragging helpless, while she impotently beats the water with the other. If young and inexperienced, he will be sure, unthinkingly, to make a dash at the bird which, flapping and quacking, just out of his reach, leads him floundering on, and

1 British Quadrupeds, p. 93. 
water-logging his water-proofs, only to find her presently, on a sudden, recover her powers and be off: while, if he had waited quietly, and looked about him, he would have seen a brood of ducklings paddling in all directions to seek for cover. "Is it conceivable," asks Mr. Mivart, "that such an act was first done by pure accident, so that the descendants of the first Duck which so acted, having inherited the tendency, have alone been selected and preserved?"1

This supposition appears, if possible, yet more improbable, when we find different species of birds adepts in acting the same part. Partridges will constantly tumble along as if with a broken wing, when their covey is in danger. I have seen a Willow-wren delude, in this manner, that most dangerous of animals, a school-boy, leading him thirty yards from her nest, and then quietly popping over the neighbouring hedge. This same year the same trick has been tried, within my knowledge, by a Reed-bunting. The common Sandpiper plays the game elaborately, pretending that both wing and leg are injured, so that it can neither fly nor run; his cousin the Snipe acts his part in much the same fashion, while the Tree Pipit and White-throat exhibit a less finished performance, fluttering along the ground as though too weak to escape. Are we to believe that these birds, and others, have all independently struck out, by accident, this histrionic talent? The dramatic touches thrown in, acrording to circumstances, are in the highest style of art. Walking into the midst of a brood of Partridges suddenly, with a dog, I have seen both old birds, in face of so imminent a danger, tumble demonstratively about, screaming as if in severe pain. That a Partridge will go through the performance of dying is attested by $\mathrm{Mr}$. Harrison Weir, the well-known artist: "A little way in front a Partridge was struggling on the ground, sometimes on her back, and then rolling over and over, till, after one or two apparently exhaustive efforts, she fell, and lay as if dead." 2 The whole thing being a deliberate

1 Tablet, May 26, I 888.

2 Bird Stories, p. 2 r. 
imposture. Father Robert Ross, S.J., gives me the following description of what he himself witnessed, in former days, on the part of a Norwegian Ptarmigan, or Ryper: "I was after deer on one of the shoulders of Snaehatten, when I put up a few Ryper. Their flight attracted the attention of an Eagle, who immediately swooped down in pursuit. One of the birds pursued turned sharp round towards me, the Eagle close after it, and dashed itself in among the rocks within twenty yards from where I stood. The Eagle could not get into the crevice, but by the flapping of its wings, and general features, could, I thought, just reach the bird with its talons, and was tearing it to pieces. I did not wish to shoot the Eagle, for fear of frightening the Deer, but was anxious to get the Ryper as an addition to my larder. Accordingly, with my stalker I made a rush and frightened the Eagle off, and on reaching the spot we found the Ryper lying, as we thought, dead, with a handful of its feathers around. The Norwegian thought I had better tap it hard on the head with his stick, before he put in his hand to reach it, but thinking it quite dead I gave the bird only two slight taps, one on the head and the other on the body, just enough to convince the man, as I was convinced, that the Ryper had given its last kick. The bird all this time never moved, but the instant the stalker put in his hand to bag it, there was a sudden quick flutter, and the next instant out rushed the Ryper through another crevice, as strong and well as ever."

Sundry insects will likewise sham death, to escape threatened death. But it is evident, as we see in the above case, that unless the deception were quite perfect, such a proceeding would only ensure destruction by awaiting it. But on the Natural Selection theory the imitation must have been very far from perfect to begin with.

The instincts called into play by birds in defence of their young, where a species has not strength sufficient to show fight, are often pervaded by the same idea, 
though it takes a different form. Approach a Blackcap's nest too closely, and down come the old birds, within arms' length, amongst the leaves around, rustling and chattering, so that you cannot but attend to them, and perhaps fancy you can catch them; while meantime, amid all their antics, they contrive to have some foliage ever between your eye and them, making it difficult even to get a full view. On the other hand, just as some tribes of birds have a style of plumage distinctively their own, so their conduct in such circumstances reveals a character equally distinct. The Titmice, amongst the smallest of our birds, will defy an intruder with a recklessness that has in it an element of the ludicrous. Nothing will induce a sitting bird to come off her eggs. A lighted match may be introduced into the hole where they lie, and the mother will only peck at the flame. I have known an instance where a collector, wishing for a Tomtit's egg and utterly unable to persuade the parent to evacuate the position, fished her out with a spoon, but before he could get his limed stick ready to procure the egg, she was in again.

An animal, moreover, exhibits sometimes an instinct in particular circumstances, to which nothing can lead up. Take for example the case of the Ringdove, witnessed by Waterton, ${ }^{1}$ which elected to build in a tree already occupied by that depredator of nests, a Magpie. The Pigeon's eggs and young escaped untouched, and as the great naturalist remarks, the bird somehow instinctively knew that it would be so, for she settled there with the danger staring her in the face.

Of the bringing of examples there threatens to be no end, so I shall limit myself to one more. The Cuckoo, as every one knows, lays her eggs in the nests of other birds. This instinct is a very singular one, and it is hard to see how, on Darwinian principles, it could have originated. Mr. Darwin tells us, "It is now commonly

1 Essays: the Ringdove.

2 Origin of Species, p. 216. 
admitted, that the more immediate and final ${ }^{1}$ cause of the Cuckoo's instinct, is that she lays her eggs, not daily, but at intervals of two or three days, so that if she were to make her own nest, and sit upon her own eggs, those first laid would have to be left for some time unincubated, or there would be eggs and young birds of different ages in the same nest. If this were the case, the process of laying and hatching might be inconveniently long, more especially as she has to migrate at a very early period; and the first hatched young would probably have to be fed by the male alone."

It is hard to see how this reasoning should on its own merits gain common acceptance. Other birds, Owls for instance, lay their eggs at intervals, as long, or longer, and the owlets first hatched help to hatch the other eggs; so that we find in an Owl's nest "eggs and young birds of very different ages." Again, the Cuckoo's stay with us is not very much briefer than that of the Swallow, which yet contrives to rear two broods or perhaps more. That the Cuckoo could easily acquire the habit of staying a little longer is evidenced by the fact that young birds linger not uncommonly till September.

But supposing that all the circumstances enumerated rendered it hard for the Cuckoo to make its family arrangements: what then? The natural consequence should be that the Cuckoo race would perish, too heavily handicapped to struggle for survival. How could its weaknesses in this regard have suggested their own remedy ? ${ }^{2}$ Here there is no question of a series of acts graduated towards the completed habit. Either an egg was laid inside another nest or outside. No egg laid outside would benefit the bird at all. An egg laid inside requires the instinct which it is supposed to originate.

1 The term final cause is, of course, not used here in its philosophical sense.

2 It might, moreover, be suggested that cuckoos should have learnt to lay their eggs at shorter intervals, those which did so obtaining a marked advantage over the others. 
Good observers, moreover, are of opnion that the Cuckoo lays her eggs on the ground, and then taking them in her mouth, so introduces them into the selected nursery. ${ }^{1}$ This, if a fact, makes the economy of the Cuckoo more singular, and distinguishes it more sharply from that of other birds. It would appear, besides, that the parent can, in the interests of its offspring, take account of circumstances. It is no hard matter for the young Cuckoo to obtain sole possession of a Hedgesparrow's or Pipit's nest, and a monopoly of the foodsupply to feed its greater bulk. It might not be so plain sailing for it amid a brood of Blackbirds. It is accordingly a significant circumstance to find, as was found this spring, ${ }^{2}$ all the Blackbirds' eggs pierced so as to prevent them from hatching.

Another strange feature in the history of this remarkable bird, is the fascination it exercises upon its adopted parents. These seem to develop a passion for its welfare more intense than in the case of their own offspring. Not only will they go on feeding it, when it is so much larger than themselves, that they have to get on its back to reach its mouth, but if their bantling happens to be taken from them, they will follow the robber to a great distance, crying piteously. Nothing is more ridiculous than to see a Meadow Pipit laboriously endeavouring to keep up with a young Cuckoo, who having great power of wing which he has not yet learned fully to control, goes ducking and dipping through the air, like a kite escaped from its string. Nay, according to Mr. Harrison Weir, ${ }^{3}$ this fascination

1 Since the above was written, I have met with conclusive evidence on the point. Mr. Hart, of Christchurch, in his interesting museum, exhibits a hen-Cuckoo and her egg which he himself watched her deposit with her bill in the nest of a Wagtail. I have also been told of a Cuckoo being shot, its mouth being found to be full of the yolk of an egg. This the keeper who shot it took to be proof positive that the bird sucks eggs, an accusation often made; but, while it does not accord with this theory, it gives clear support to the other.

21888.

8 Bird Stories, p. 17. 
is not confined to the foster-parents. In the case of a young Cuckoo, which he watched, not only did the Hedge-sparrows responsible for it attend to its requirements, but a Greenfinch, which had nothing to do with the business, came to help them. He tells us that in another case, when a young Cuckoo was hung up in a garden in a parrot cage, two Wrens, which were building near, came, and, getting through the bars, commenced to feed him: being presently joined in the office by a pair of Hedge-sparrows. Even when they had finished their own nest, one of the Wrens continued to feed the young monster. Such an instinct can clearly do nothing to serve the fortunes of the race which exhibits it, for the young Cuckoo commences his career by the destruction of the young birds in the nest he occupies : being therefore taken by the greatest of observers as the type of a thankless usurper's treatment of his dupes;

And being fed by us, you used us so,
As that ungentle gull the Cuckoo's bird,
Useth the Sparrow : did oppress our nest :
Grew by our feeding to so great a bulk,
That even our love durst not come near your sight.

Now, leaving the question of their origin, we have to examine the other question as to the transmission of instincts. Is it conceivable that they should descend from one generation to another unless there were in the creature's nature something tending to induce the descent? Can that something be anything but the machinery of purpose to secure an end?

Some of the examples already cited, under the first head of our inquiry, will serve to introduce us to the second. Most remarkable of these is the care of neuter insects, which, doing nothing to propagate their race, can do nothing to transmit instinct or anything else. Yet these neuters do all the work of the community, and require the most complicated instincts to do it. To fit them for their object, even their bodily form has often to be 
entirely different from that of the males and females, and in some species the neuters destined for different branches of work differ entirely from one another: thus in one kind of ant there are working neuters and soldier neuters, with jaws and instincts extraordinarily different; and in another kind, the workers of one caste, and one alone, have a wonderful sort of shield on their heads, the use of which, it may be observed, is quite unknown. Yet these neuters are t'ie offsprings of males and females, none of whom, and none of whose ancestors, ever did a stroke of work in their lives. How then can their instinct, or its instruments, have possibly been developed by Natural Selection only? Mr. Darwin is, of course, too acute not to see the difficulty, and too honest to dissimulate it. $\mathrm{He}$ calls it the most formidable he has to meet, but proceeds to meet it by an elaborate explanation. Selection, he says, may be applied not to the individual only, but to the race, in order to gain the required end. The good of the race requiring the production of neuters, thus variously modified in form and instinct, those fertile instincts may alone survive, which tend to produce neuters so modified: and thus may Natural Selection suffice for the production. The realms of imagination are, no doubt, infinite, and within their sphere such ramifications of fortuity are perhaps conceivable: but have we not reached the bursting strain of improbability? That direct descent should develop the geometrical instinct of the Working Bee is hard enoligh to believe, but here the difficulty is raised to the square. And even if the sum of improbabilities thus piled up be not overwhelming, still the explanation so suggested does not avail so much as to touch the case of slave ants. They exhibit an instinct beneficial, not to their own race, but to another: it can be of no advantage to the tribe from which they are taken, that so many of its members should be dragged away to bondage, or, at any rate, 
if it were so, why should that tribe fight to prevent it, and suffer mutilation and death in the struggle? By what possible process can it have been brought about, that black queens and drones should have been so selected as to produce neuter insects, which will make good slaves for red ants, at the same time handing on to their progeny an instinct that makes them perish in the attempt to avoid that very service for which they have been so laboriously prepared? Here, then, we are clearly beyond the sphere of possibility itself, and I cannot see how in this case, at any rate, the Darwinian explanation is even "to the imagination far more satisfactory."

The case of neuter instincts would then seem to be final, as against the theory, but there are many others, which, to some minds at least, will appear equally conclusive. Such, for example, are the actions performed by many animals and by many human infants, absolutely without instruction or previously acquired knowledge. We know from the experience of our own minds that our reason is not self-sufficient, that it requires a premiss on which to build a conclusion, and can judge how to act, only by drawing upon the teachings of authority or of experience. We all know how to proceed to eat our dinner, but we do not know how we learnt to take our first sustenance. What taught us that the lips and not the hands were the proper organs to employ? Obviously not reason, which would have been utterly powerless in such a case. Yet there was a guide which directed us, and directed us rightly, the voice of instinct.

This, Mr. Wallace ${ }^{1}$ seems inclined to deny, on the ground that "this is one of the simple acts depending on organization." Most unquestionably; but instinct is precisely a part of the organization, and for animals the most essential part of all. Nor, as we have seen, can it be explained away, by calling it inherited habit, 1 On Natural Selection, p. 206. 
for that by its very idea requires an instinctive principle which is not habit.

In such a case as this, we are therefore in presence of instinct utterly divorced from those conditions in which knowledge can be imparted. Yet how much do creatures in such circumstances practically understand. The Chicken will chip the shell, which to animals stronger and more experienced than itself would be a hopeless dungeon. Emerged from the shell, it knows how to peck and run. I think it is White, of Selborne, who says that if held up to a window it will eagerly devour flies, but refuse a Wasp. That young ducks will take to the water, in spite of all teaching, many a perturbed foster-mother of a hen can witness. Young cocks will spar before their spurs are grown; and young adders raise themselves to strike, when, as yet, they have no fangs. A young Water-ousel taken from the nest and brought to the water will dive and find hidingplaces to crouch in, as though familiar with the work. Young wild-fowl hatched in captivity, as we may see in the London parks, descrying a large bird in the air, will at once take the alarm, hiding in the grass or skulking in broken ground, so as to make themselves as inconspicuous as possible to a Hawk; providing against a danger which they have not experienced, by a device which they never have been taught. Young Gold-crests, frightened suddenly from the nest they have never yet left, will show themselves equally at home amongst the foliage of a fir-tree, fluttering from twig to twig, and running along branches with extreme dexterity. As the Dipper in the water, and the Gold-crest among the firs, so the young Swallow finds himself at home in the air. Only two days ago an experience to this effect befell me with a House-martin. A nest with young ones, being found in the first week of October, ${ }^{1}$ I observed it daily to see whether, as in some cases, the migratory instinct would overcome the parental, and induce the old birds 
to abandon their brood to their fate. ${ }^{1}$ On the 8 th of the month the young were still in the nest, two of them perpetually having their heads at the door, and the old birds were assiduously feeding them. On the gth there was no trace of birds, either in the air or at the door, but something could be seen moving inside. This, on examination, proved to be a solitary young one, crouching forlorn upon the floor. It was brought down and given the chance to fly, when, like the young Bee described by Réaumur, it knew all about it, going off as though it had done nothing else all its life, soaring and circling high in the air, and apparently hawking after insects. I watched it for about a quarter of an hour, and left it so occupied.

If with Mr. Wallace we define instinct to be "the performance by an animal of complex acts, absolutely without instruction or previously acquired knowledge," 2 cases like this would certainly appear to be included. There are, however, acts still more complex, which seem equally instinctive: so complex as to preclude the idea that they can be governed by anything but an inbred guiding power, a part of the creature's self. To this $\mathrm{Mr}$ Wallace appears to demur. He inclines to believe that even the song of birds and the construction of their nests, are not instinctive to them, but learnt by experience. As to the nests, he holds that we shall have no satisfactory evidence of instinct till eggs shall have been hatched by steam and the young birds placed in a covered garden, with plenty of building materials, to see what kind of nest they will construct. I do not know

${ }^{1}$ While observing the nest, I remarked that though the young birds appear to fight selfishly for the foremost place at the door, to secure food, yet just before a visit of the parent, one that held the position, who had been fed on the previous visit, drew suddenly back and another came forward. This looked very like another case of self-denying instinct. Were there not some such provision, a weak nestling might easily be starved in the background, as the parents stay but a moment at the opening, and feed the bird before them.

${ }^{2}$ Natural Selection, p. 204. 
that this experiment has been tried, ${ }^{1}$ but naturalists of an experimental turn have often put the eggs of one bird in the nest of another. Thus Waterton writes to Mr. Ord, July 4, I833: "This season I have made Jackdaws hatch Magpies, and Magpies Jackdaws; Carrion Crows have brought up Rooks, and Rooks Carrion Crows. It is quite laughable to see a brood of young Jackdaws following an old Magpie, and vice versa." Does any one for a moment suppose that when mature these birds would not instinctively know their own kind, and next season build their nests after its fashion, though, in the case, for instance, of the Jackdaw and Magpie, totally different from that in which they have been reared?

It must also be allowed that even supposing a young bird to occupy his leisure with inspection of the domicile in which he lies, he will need something like instinct, and plenty of it, to compose a similar one, when his own time comes. Mr. Wallace ${ }^{2}$ implies that the instinctive character of birds' architecture is discredited by the observation that they severally employ the materials that naturally lie in their way: thus the thicket-dwelling Wren uses moss ; Kingfishers, fish bones ; Carrion Crows, fur or wool; the earth-grubbing Rook, fibrous roots; and the pool-haunting Swallow, mud and clay. But is this quite a fair account of the matter? To say nothing of the Tailor birds and Weaver birds of other climes, we find most remarkable instances amongst our own species, of materials both carefully chosen and artistically used. The Bottle-tit, besides moss for the walls of his structure, and feathers for the lining, weaves the whole together with fine threads of wool, felts the dome, and makes it rain-proof, with moss and lichens, wool, and the web of spiders' eggs; and coats the outer surface with white

${ }^{1}$ Since writing the above, I have been informed that bird-fanciers are in the habit of substituting an artificial nest for that built by Canaries; and that the young so reared nevertheless build after the manner of their species.

${ }^{2}$ Natural Selection, p. 216. 
lichen so as to resemble tree bark. The Gold-crest hangs his nest, of moss lichen and wool, from the boughs of a fir-tree, in such a manner as to be partially suspended from one and supported by another. The Chaffinch uses spiders' webs to produce what Waterton calls his paragon of perfection. The Thrush manufactures a varnish of mud or cow-dung and rotten wood, wherewith to line his nest, and the arboreal Nuthatch plasters up the approach to his, except one opening, very neatly, with clay. In the choice of materials, too, birds will exhibit a power of discrimination which man could rival only by a laborious process. Martins, for example, seeking clay for their nests, will unanimously select one puddle out of fifty equally convenient, their diagnosis of the quality of its contents being seemingly instantaneous, while we, to come to a sound conclusion, should have to institute a long and tedious comparison.

As to song, Mr. Wallace tells us that Linnets, educated in captivity under Larks, and Goldfinches under Wrens, learn the notes of their instructors instead of their own. But captivity, as is well known, alters habits in an extraordinary degree; though even in captivity a young Skylark, without any instruction at all, will acquire his native song. But in a wild state, is it probable that Waterton's young Jackdaws learnt to chatter like Magpies, or his Magpies to yelp like Jackdaws? If we were, on a large scale, to interchange the eggs of Blackbirds and Thrushes, or of Nightingales and White-throats, should we expect any notable results to be apparent in the minstrelsy of the district? One argument to the contrary nature has exhibited in the Cuckoo, which reared in the society of strangers, and with their notes in his ear, yet sticks unfalteringly to the tune, which only by instinct can he recognize for his own. Again, how should a young bird learn from its parents the art of mocking whatever sounds it hears? Our common Sedge Warbler, for instance, will not only mimic the Sparrows, Chaffinches, and Blackbirds around it, but should it chance to hear the peculiar cry of a Guinea- 
fowl, will add this also to its repertory. Obviously it cannot be parental training which enables it to do so.

None of these instances, however, brings such weighty testimony to bear upon the matter, as do the phenomena of migration. These have ever been a marvel to the mind of man, and, to explain the mystery they offer, he has been prompt to believe that if the Stork knoweth his way in the air, and the Turtle, and Swallow, and Crane, the time of their coming, it has been because they are in the leading strings of a power be cannot see.

The broader features of these phenomena are known to everybody. We are all aware that the Swallow and the Nightingale, the Cuckoo and the Corncrake, come to us in spring and leave us in autumn, and that the Woodcock, the Snow-bunting, and the Fieldfare reverse the process, coming for the winter months and wandering away to northern lands to breed. The journeys they undertake, in their oft-repeated change of quarters, are prodigious. The Stork, who spends his summer season in close acquaintance with civilized men, his next erected on the housetop of a Dutch or German village, is to be found in winter by the great African lakes, amid Crocodiles and Hippopotami; the Warblers travel to and fro between our woodlands and Morocco, or Asia Minor, while our Wild Ducks and Fieldfares betake themselves for the nesting time to Lapland or Siberia, even within the Arctic circle. Why our summer visitors should ever come to us, or our winter visitors ever depart, we cannot tell. It is not food, it is not warmth, we know not what it is, that they gain by the exchange. Yet year after year they unhesitatingly embark on the voyage, which we cannot understand how some of them accomplish. The Corncrake, during his stay with us, seems hardly able to fly the length of a field; how does he ever get across the seas? How do the tiny Gold-crests, five full-grown specimens of which weigh less than an ounce, come, earning their title of the Woodcock's pilots, across the German Ocean? 
What prompts them to start on such an enterprise? and what teaches them to know how to set about it? Yet this is not all the wonder. Recent observation has established the fact that the routes followed in migration are well defined, the sea voyage being by no means reduced to a minimum. ${ }^{1}$ Whence comes the knowledge which makes it possible to steer such a course? 2

It has been attempted to maintain that here too, as well as in music and architecture, the experience of the old is communicated to the young, and that it is a matter, accordingly, not of instinct, but of education. The teachings of observation, however, are all the other way. In the first place, to say that any bird, old or

${ }^{1} \mathrm{We}$ are told that these routes follow the lines of least depth of water, and it is inferred, that the birds having grown accustomed to these lines, while they were dry land, have been unable to forget them ever since. Of course, if the fact be correctly established it must be accepted; but otherwise grave and obvious objections present themselves. In flying over land, the birds, I believe, follow the river basins, - the valleys, not the hills. The track of what once were hills, the shallower waters, cannot therefore be the oldest memory of the race. If that older memory has been supplanted by a newer why not that again by a third? It would seem that it should have been so most emphatically on principles of Natural Selection. Enormous numbers of birds perish in the sea passage. Tens of thousands, we are told by Dr. Robert Brown, are drowned yearly. Here is a case where Natural Selection should work at high pressure. Birds accidentally taking a shorter route should have been so favoured in the struggle for existence as, by this time, to have produced a race following a mathematical straight line betwixt the nearest points, from shore to shore.

2 An extraordinary explanation has been imagined by an observer quoted by Mr. Romanes. $\mathrm{He}$ is of opinion that birds always stari their migration when the wind is from the south, and that the instinct is fully accounted for by the pleasurable sensation they experience in flying against the warm breeze. This appears to be an excellent example of the theoretical manufacture of facts. On the 9th of October, when the Martins before mentioned took their departure, the wind was all day N.N.E., except for a short period when it got round to N.N.W., as shown by its self-registration in our Observatory. 
young, has the minute geographical memory which would be required to steer by between Lancashire and Morocco, seems no more in accordance with what we know of them, than to say that worms have a sense of humour. What possible co-ordinates would serve them out of sight of land, over the tracts of the unfruitful sea? Migration, moreover, is performed more by night than by day, and to judge by the mad way in which the birds then dash up against lighthouses, it would seem as though they were hurried irresistibly on with far less power of self-control than they ordinarily exhibit; as young Salmon confined in a pond will throw themselves on the bank when the season for going to the sea arrives. For it must be remembered that birds are not the only migrants: the wanderings of the Herring and the Salmon are still more extraordinary, and of them it is a still less hopeful task to attempt any explanation. What guiding lines can be found in the waste of waters, even if it be true, as has gravely been asserted, that Salmon-smolts go down their native river tail first in order to observe what should be their way up again?

Turtles, also, which at other times spread themselves far abroad in the ocean, manage to hit off at the breeding season the little island of Ascension, a tiny speck in the midst of boundless waters, which many mariners with the aid of chart and sextant have not been able to find.

But the most extraordinary and inexplicable of all migratory instincts, is afforded by a quadruped, the Lemming. This little animal, a member of the Mouse family and a close relative of the Water-rat, lives habitually in the east of Norway, but at irregular periods, varying from three years to ten, a large portion of them set forth on the most mysterious of pilgrimages. Their course is directed due west, and thus does not lead them to the regions where more plentiful food might be obtained, in the south. They spend more than a year moving resolutely on, turning neither to the right nor to the left for any 
obstacle, swimming lakes and climbing houses which lie in their path. They winter beneath several feet of snow, and rear families on their journey. All the way along they are accompanied by another crowd of travellers for whose movements their migration is the signal. The Fox, the Stoat, and the Hawk find a ready livelihood provided for them in the ranks of the caravan; the Great Snowy Owl is on these occasions alone to be found in its best condition : even such pacific animals as Reindeer and Goats develop ferocity in presence of the Lemming, stamping them to death, and, according to some authorities, actually devouring them. All this makes it hard enough to understand what benefit this migration brings to the migrants, but it is all as nothing with the final issue. Steering ever due west the Lemmings arrive at last at the shore of the Atlantic. This obstacle they treat like all the others. On the first calm day they plunge into the sea and the whole multitude perishes to its last member, the front of the host still pointing to the west. As Mr. Romanes tells us, " "No faint heart lingers on the way, and no survivor returns to the mountains." So vast are the number thus immolated, that in November, 1868, a ship sailed for fifteen hours through a swarm of swimming Lemmings. To explain this instinct has baffled, as well it might, the ingenuity even of theory. Mr. Wallace suggests that Natural Selection has played an important part in causing migration, by giving an advantage to those animals, which enlarge their breeding area by travel. Mr. Crotch, however, pertinently remarks that, "if none return or survive, it is difficult to say what becomes of the fittest." Having disposed of Mr. Wallace's explanation, Mr. Crotch proceeds to give his own, which is even more remarkable. He finds in the instinct of the Lemming an argument for the existence of the island of Atlantis, that vague and shadowy land spoken of by Plato

1 Mental Evolution in Animals, p. 283. 
and Diodorus. To this, when it was land, the Lemmings, according to Mr. Crotch, acquired the habit of migrating, and the habit has persisted though the land has sunk fathoms deep in the ocean. To this theory, which is adopted likewise by a writer in the Encyclopadia Britannica, there is the obvious objection that the Lemmings, which do not migrate, alone perpetuate the race, and must therefore be supposed to hand on the instinct, which in their own persons they do not exhibit. Is it not more truly scientific to acknowledge that we know nothing at all of the matter, and cannot even conceive a satisfactory hypothesis? This suicidal instinct is no doubt mightily convenient to the world at large, in so effectually checking the unlimited increase of these prolific rodents, but within the limits of their race it cannot be said to have any advantages to recommend it for Natural Selection.

But we need not weigh these improbabilities, however grave they be, in discussing the question as to whether the knowledge required for migration be acquired by education or implanted as instinct, for, as a matter of fact, the young birds of the year, in the case of the great majority of species, migrate before the old ones, and perform their first journey with no guide but that which they can themselves supply. As if to leave no doubt upon the subject, there is one notable exception. The Cuckoo, reared, in almost every case, in a non-migrant's nest, ${ }^{1}$ having no converse with its own parents, leaves the country a month after they have gone, and when every possibility of a personally-conducted voyage has vanished.

Still more hopeless would be his task who should maintain that in the case of fish, "the voiceless children of the incorruptible," instruction of any sort is imparted by the older to the younger generation. Salmon are of

${ }^{1}$ Far most commonly in that of the Meadow-pipit, and after that of the Hedge-sparrow, or Wagtail. 
all migratory fish those whose history we know best, and though, to tell the truth, we know next to nothing about them, it is yet quite evident that the fry not only do not know their own parents, but keep sedulously out of the way of every member of their kind which is large enough to eat them; for fish are sad cannibals, and when there is question of a dinner the claims of relationship are apt to be little regarded. The Smolts go down to the sea in "schools" on their own account, quite apart from the full-grown fish, waiting for a flood to take them over obstacles which they have never had an opportunity of observing. Should the water remain too low for travelling, they are consumed with a fever of restlessness, causing them continually to throw themselves out of the water; and if confined in a pond they will, as already mentioned, throw themselves on to the bank, in obedience to their irresistible yearning to be off. In the case of a fish, therefore, the idea of guidance is out of the question: to suggest it in connexion with the Turtle, would partake of the ludicrous. As we have seen, no Lemming ever makes the journey twice, and none can therefore serve as a guide to the company.

Such are a few items out of the mass of evidence, that the phenomena of instinct affords us in our investigation of nature. It is, I think, undeniable that even assuming an instinctive principle to start with, there are many difficulties in the way of the theory which would trace all the forms of instinct now existent to the perpetuation, through Natural Selection, of accidental variations happening to be serviceable. It seems impossible to conceive that means so nicely adjusted, were elaborated by any power not having the end in view which they so accurately attain; in some cases their transmission appears to be physically impossible; in all which I have cited there seems to be conspicuous absence of any medium whereby knowledge may be imparted.

Yet of these instincts each and all serve an end. 
They play their part, and a supremely important part, in sustaining those laws of nature, the investigation of which is the whole object of science, as their harmony is her boast. Was such a work achieved without a plan? Did Nature grope her way blindfold to its accomplishment, unconscious of the reign of law she was herself establishing? That order of the universe which, when recognized, overpowers our minds with admiration, was it no more esteemed than chaos till our minds recognized it? As in a looking-glass there can be no image till there be an eye to see it, was the idea of harmony unsuggested by the facts of Nature till the natural philosopher arose upon the world? So must it have been unless there was a purpose that saw itself reflected in their accomplishment: it would appear to be as imaginable a proposition that two and two did not make four till the first multiplication table was constructed, or that the properties of triangles were nonexistent till geometric man was developed.

Science, moreover, looks confidently forward, as well as back. She counts on the discovery of new laws, and the disclosure of marvels in Nature as yet unknown. The principal organ in this country announces itself as destined to set forth from week to week "the grand results of scientific research." What are the elements of the calculation by which these are prognosticated? Can we assume that we shall find in Nature fresh proofs of order, unless we be assured that order has been there before us, and that all the phenomena we discover are traces of a power that has made a weight for the winds and weighed the waters in measure, given a law to the rains and appointed a way to the sounding storms? 



THIS BOOK IS DUE ON THE IAST DATE
STANPED BELOW

AN INITIAL FINE OF 25 CENTS WILL BE ASSESSED FOR FAILURE TO RETURN THIS BOOK ON THE DATE DUE. THE PHE FOURTH WILL INCREASE TO SO ON THE SEVENTH DAY DAY AND OVERDUE.

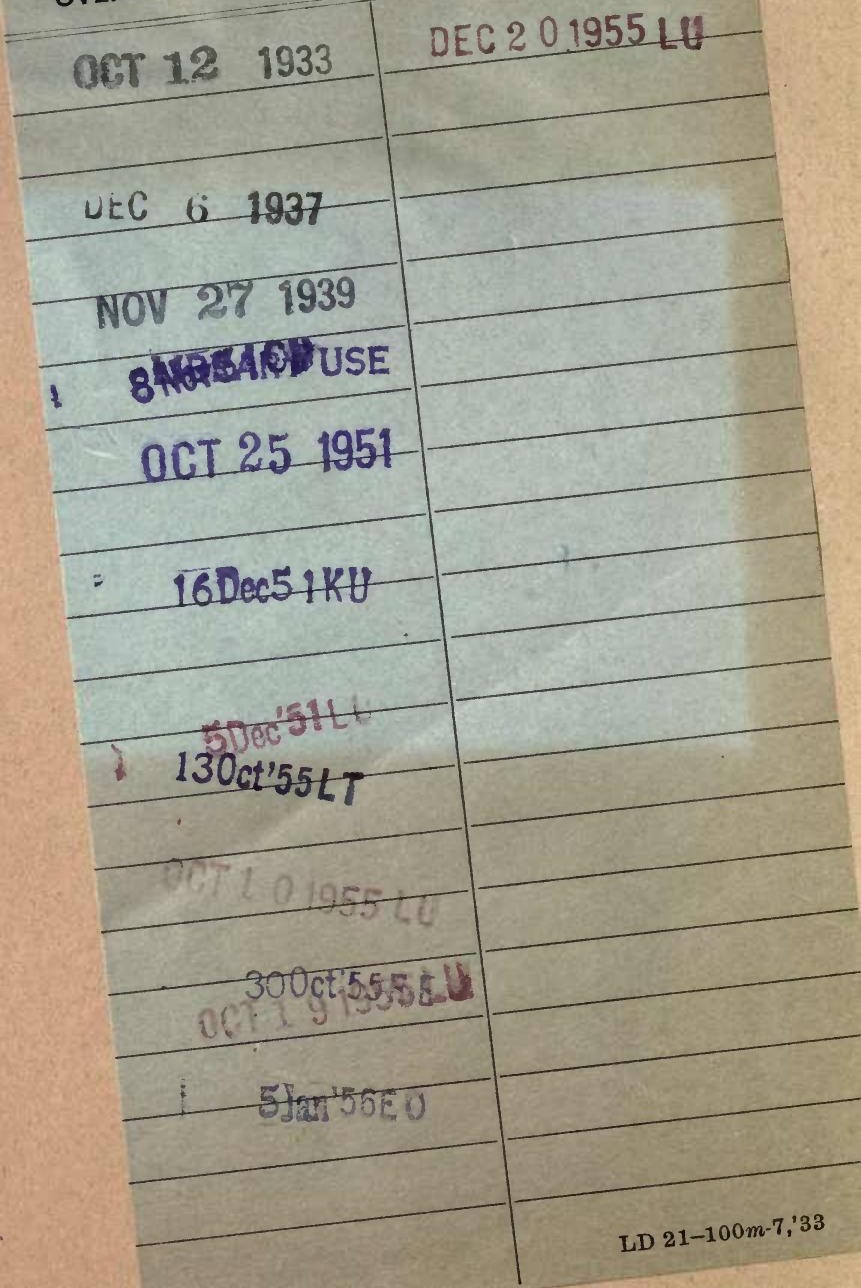




\section{YB 17612}

7.

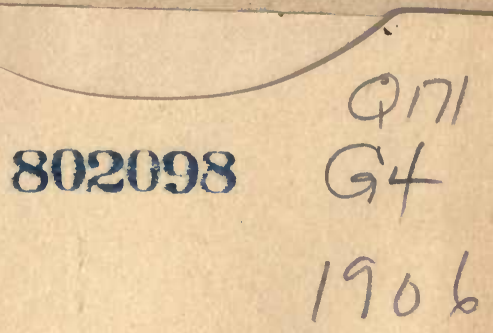

UNIVERSITY OF CALIFORNIA LIBRARY 
